\title{
OFF THE FIELD: \\ Reimagining sport, community, and landscape at Polo Park, Winnipeg
}

\author{
by \\ Liane Lanzar \\ A thesis submitted to the Faculty of Graduate and Postdoctoral Affairs \\ in partial fulfillment of the requirements for the degree of \\ Master of Architecture \\ in \\ Azrieli School of Architecture and Urbanism \\ Carleton University \\ Ottawa, Ontario \\ (C) 2020 \\ Liane Lanzar
}


ABSTRACT

Off the field imagines the re-appropriation of an urban stretch of Omand's Creek, which once meandered through Polo Park in Winnipeg, Manitoba. What was formerly an area dedicated to physical activity and appreciated for its natural landscape, is now a regional shopping district covered in concrete parking lots.

The relationship between humans and nature is explored through the physical separation between each other and the outdoors. The project responds to the needs of the site by restoring the urbanized stretch to the diverse recreational landscape it once was to reconnect the body, community and the environment. 
PREAMBLE

Physical activity, which is an integral part of our lives, has disappeared from our everyday routines with the growth of urban environments. Increasing inactivity has made physical activity unnatural and at times inaccessible. Developing and maintaining active design in urban areas can not only assist with people's mental and physical health, but can also improve the impact we have on our environment.

While this architecture project examines the relationship between sport and the city, it is less about urban planning and more about community development through the architecture, landscape and a visionary rezoning of the site. The project sets out to bridge the gap between activity in the landscape and the activity of gathering, and how the design of pavilions within a recreational landscape can navigate between the two. 

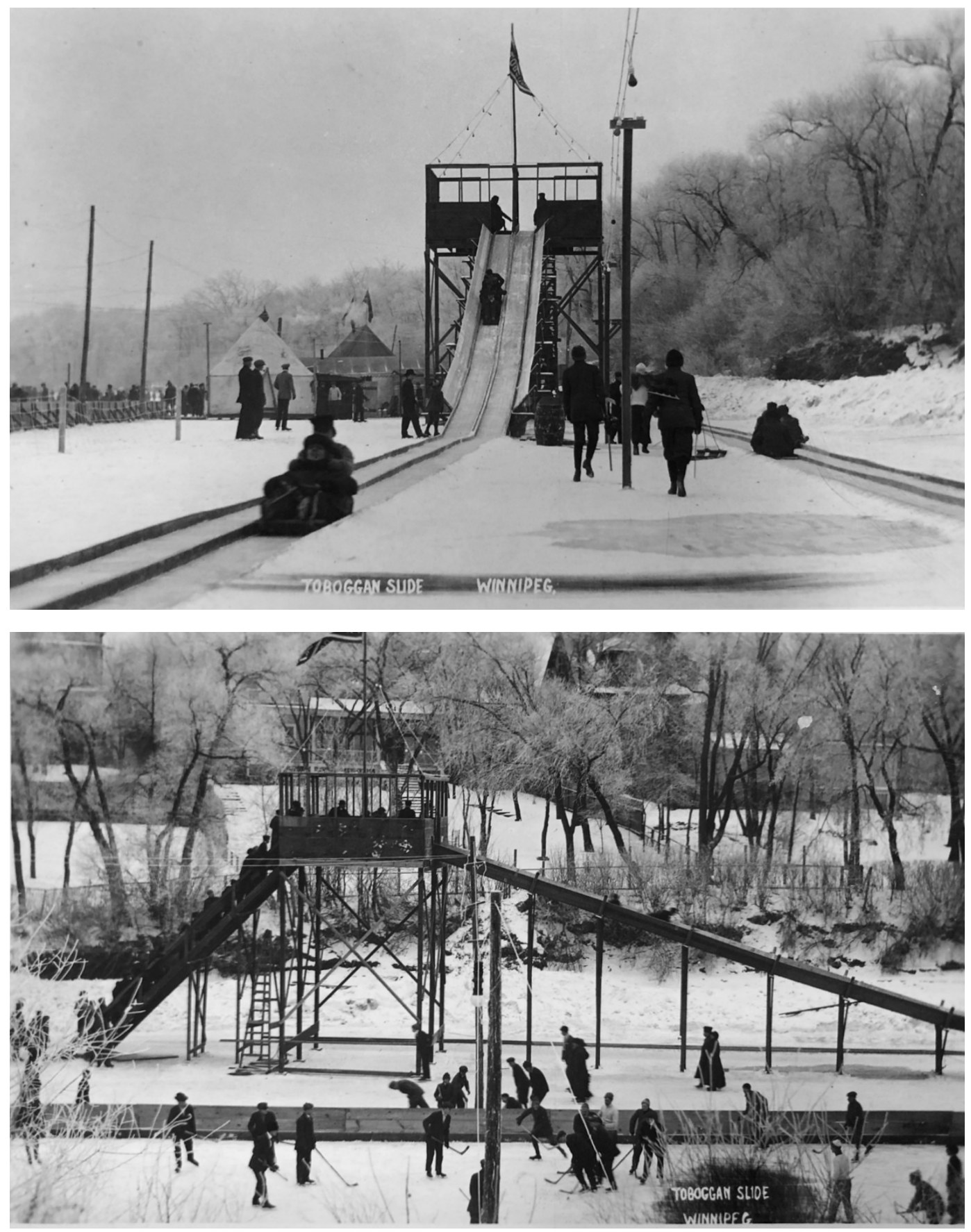

Figure 1. Toboggan Slide, c. 1915, Assinaboine River, Winnipeg.

Figure 2 . Toboggan Slide, c. 1915, Assinaboine River, Winnipeg. 
ACKNOWLEDGMENTS

It is the people around you that shape who you become.

I would not be where I am today without them.

To my Lola, for introducing me to the beauty of making and contributing to the built environment. To my parents, Amabelle and Donato, for their neverending support and encouragement. To my brother, Mark, for never letting me win. It always made me strive for more.

To my childhood teammates, who have become lifelong friends, I am looking forward to making more memories with you all.

To my advisor, Inderbir Riar, thank you for your incredible insight and enthusiasm throughout this project. It was truly a rewarding experience with your guidance and advice.

To the many professors, instructors, staff and studio mates along the way, it has been a challenging experience that you all made worthwhile.

And finally, to Kevin Complido for being by my side since our first-year studio. I cannot imagine getting here without you.

Thanks team. 
TABLE

OF

CONTENTS i Abstract

ii Preamble

iv Acknowledgments

vi List of Illustrations

o1 Introduction

06 Chapter 1: Themes of Research
1.1 Lungs of the City
1.2 Promoting Urban Activity
1.3 Arena of the World
1.4 Fields of Knowledge

21 Chapter 2: Site
2.1 Heart of the Continent
2.2 Polo Park
2.3 Omand's Creek

45 Chapter 3: Initial Studies

$$
\begin{aligned}
& \text { 3.1 Cards of Recreation } \\
& \text { 3.2 Composite Drawings } \\
& \text { 3.3 Site and Building Studies }
\end{aligned}
$$

58 Chapter 4: Off the Field
4. 1 Site Proposal
4.2 Building Proposals

$\begin{array}{ll}81 & \text { Image Sources } \\ 85 & \text { Bibliography }\end{array}$ 
LIST

OF

ILLUSTRATIONS
Figure 1. Toboggan Slide, c. 1915, Assinaboine River, Winnipeg.

Figure 2. Toboggan Slide, c. 1915, Assinaboine River, Winnipeg.

Figure 3. Skating Scene Winnipeg, c. 1925.

Figure 4. Quotation from Images of Sport in Early Canada, Montreal: McGillQueen's Univ. Press, 1976.

Figure 5. Doll and toy toboggan, 1920-30

Figure 6 . Final Model Perspective.

Figure 7. Currier and Ives, Central Park, Winter, The Skating Pond, 1862.

Figure 8. YMCA Fundraising pamphlet for the Tulsa, ca. 1909, Oklahoma.

Figure 9 . Y.M.C.A. Building, 1907, Winnipeg,

Figure 10. YMCA campaign clock at the corner of State \& Madison, 1908, Chicago.

Figure 11. YMCA campaign clock, ca. 1915, Foochow, China.

Figure 12 . [German Olympian, Luz Long, befriends Jesse Owens at the 1936 Berlin Olympic Games in Nazi Germany]

Figure 13 . Victoria Skating Rink, 1863, Toronto.

Figure 14. W.C. Chewitt and Co., Lacrosse, 1856-70, lithograph, Toronto.

Figure 15. Snowshoes

Figure 16. Group of immigrants arriving at CPR Station, 1927, Higgins Avenue and Main Street, Winnipeg.

Figure 17. A view of the lake in Assinboine Park in Winnipeg, 1920-1950

Figure 18 . [1967 Pan-American Game news articles]

Figure 19. Champion of the Century

Figure 20. Transportation Map of Greater Winnipeg, 1941.

Figure 21. Polo Park advertisement, 1925, Winnipeg Free Press.

Figure 22. Polo Park Shopping Centre advertisement, 1959.

Figure 23. Outdoor activity at Omand's Creek

Figure 24 . Tobogganing at Omand's Creek

Figure 25. Plan of River lots in the parishes of St. John, St. James and St. Boniface, 1874.

Figure 26 . T. Eaton Company Store in Portage Avenue, Winnipeg.

Figure 27. Eaton Park Place Golf Course surrounding Polo Park Racetrack.

Figure 28. Polo Park Postcard, 1956.

Figure 29. Victory Gift in the Polo Park Winner's Circle, 1948.

Figure 30 . Drawings for Polo Park Shopping Centre, Winnipeg, 1958.

Figure 31. Aerial view of Polo Park Shopping Centre, ca. 1960, Winnipeg. 
Figure 32 . View to Simpsons-Sears, with sculptural Sundial Jim Willer and Duane

Eicholz, ca. 1959.

Figure 33. George Swinton's Acrobats (Concrete), ca. 1959.

Figure 34. Polo Park Mall Postcard, ca. 1963.

Figure 35. Aerial Photograph of Polo Park area, ca. 1980, Winnipeg.

Figure 36. Canad Inns Stadium

Figure 37 . Line up for Jets tickets, 1978, Winnipeg Arena.

Figure 38. Target Polo Park, 2015.

Figure 39 . Bluestem Nature Park

Figure 40. Garbage Hill

Figure 41 . The Story of an Old Garden

Figure 42. Out for a Good Time

Figure 43 . Site History

Figure 44. Project Site

Figure 45.Site exploration: south view of the creek, October 2019

Figure 46. Site exploration: north view from walking path, October 2019

Figure 47 .Site exploration: south view of the creek, December 2019

Figure 48. Site exploration: north view from walking path, December 2019

Figure 49. Site exploration: north view from bridge, December 2019

Figure 50 . Site exploration: south view toward walking path, December 2019

Figure 51. The Surface Waters of Winnipeg, 1874.

Figure 52. Aerial photograph of Polo Park Racetrack during the 1950 Flood.

Figure 53. Omand's Creek flooding at Portage Avenue, 1950

Figure 54 .Proposed By-Law

Figure 55. Omand's Creek park sledding-ready.

Figure 56 . Free Press carriers' toboggan party at River Park

Figure 57. Playing Cards

Figure 58. Game Play

Figure 59 . Composite Drawing I

Figure 60 . Composite Drawing II

Figure 61 . Composite Drawing III

Figure 62 . Composite Drawing IV

Figure 63 . Site Study I - plan

Figure 64. Site Study I - roof

Figure 65. Site Study II - plan

Figure 66. Site Study II - spaces

Figure 67. Sketch Studies 
Figure 69. Outpost studies

Figure 70. Seasonal Port Entrance Perspective

Figure 71. Final Models

Figure 72 . Site Plan Proposal

Figure 73. Winter Perspective

Seasonal Port and Toboggan Slide

Figure 74. Seasonal Port and Restaurant

Figure 75. Picnic Pavilion

Figure 76. The Gymnasium

Figure 77. Winter Site Section - Seasonal Port

Figure 78. Summer Site Section - The Gymnasium

Figure 79. View from the Platform

Figure 80 . View from the Boardwalk

Figure 81. Approach toward the Gymnasium

Figure 82 . View toward Seasonal Port Dock

Figure 83. South end of the Platform

Figure 84 . Intersection at Picnic Pavilion

Figure 85 . North Buildings

Figure 86. Seasonal Port Plan

Figure 87 . Entrance Plaza

Figure 88. Pathway to Seasonal Port

Figure 89. View toward Seasonal Port Storage

Figure 90. Lookouts and roofscapes

Figure 91. Restraurant \& Cafe Plan

Figure 92. Picnic Pavilion

Figure 93. Picnic Pavilion Entrance Plan

Figure 94. Picnic Pavilion view from walking path

Figure 95 . Picnic Pavilion view from main path

Figure 96. Picnic Pavilion perspective

Figure 97. Gymnasium model

Figure 98. Gymnasium Plaza

Figure 99. South side of Gymnasium

Figure 100. Gymnasium Plan

Figure 101 . L.B. Foote, Skating on the Red River at River Park, Osborne Street and Churchill Drive, 1914, Winnipeg. 


\section{"At its best, play is a kind of research, and like all research at the adult level, it should be an adventure and an experiment that are greatly enjoyed."}


To everything there is a season and in Canada the seasonal changes are the most dramatic in the world. In earlier days all sports tended to be identified with the seasons.

Fall was the time for football, and for hunting and shooting as the game birds began their long journey south. There could be no hockey or curling until the ponds, lakes, and rinks

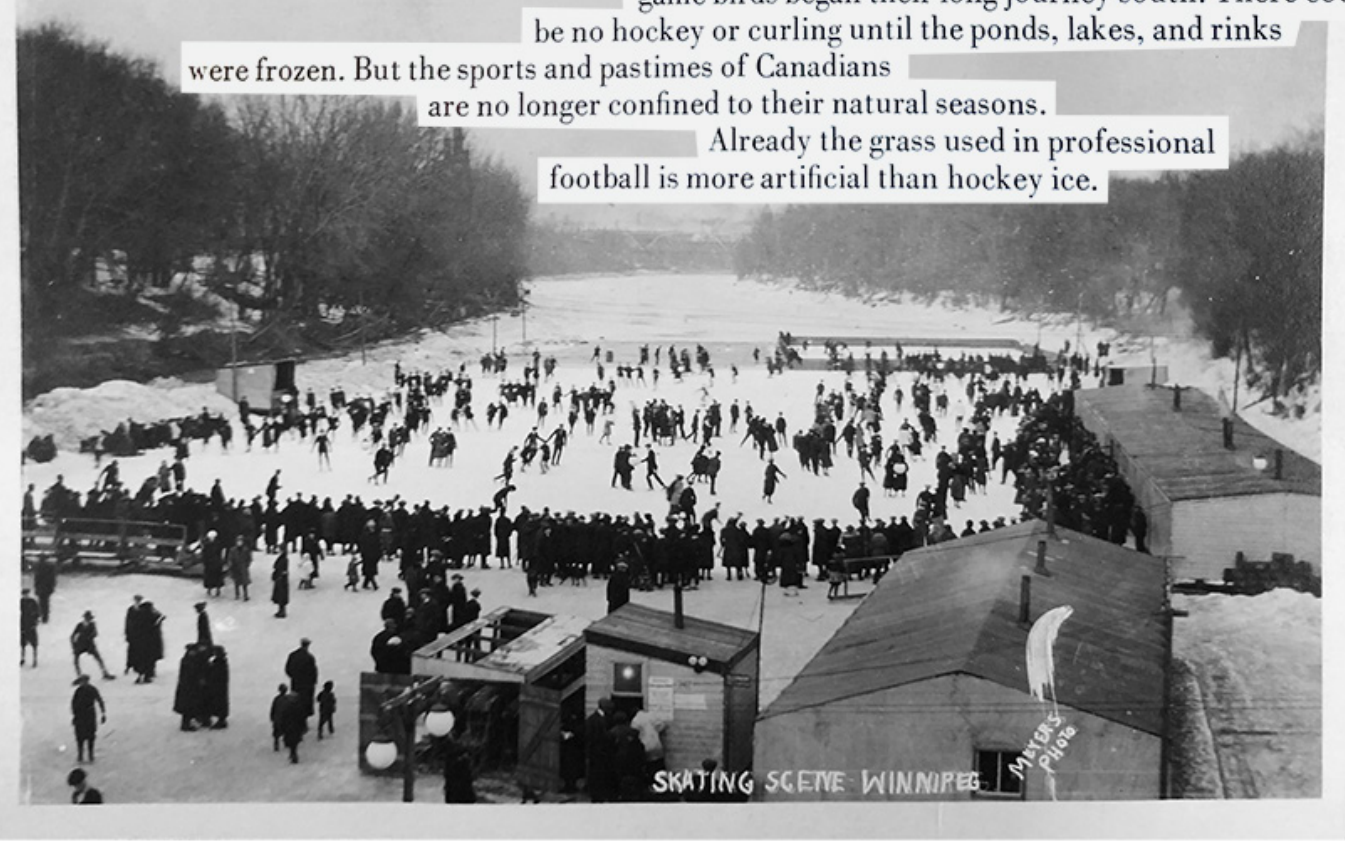

Figure 3. Skating Scene Winnipeg, c. 1925.

Figure 4. Quotation from Images of Sport in Early Canada, Montreal: McGill-Queen's Univ. Press, 1976 


\section{Introduction}

Figure 5. Doll and toy toboggan, 1920-30

1. "Sport (v.)." Index. Accessed March 8, 2020. https://www.etymonline.com/word/sport.

2. Nancy J. Dunbar and Hugh MacLennan, eds., Images of Sport in Early Canada: Images Du Sport Dans Le Canada d'autrefois (Montreal: McGill-Queen's Univ. Press, 1976), 11.

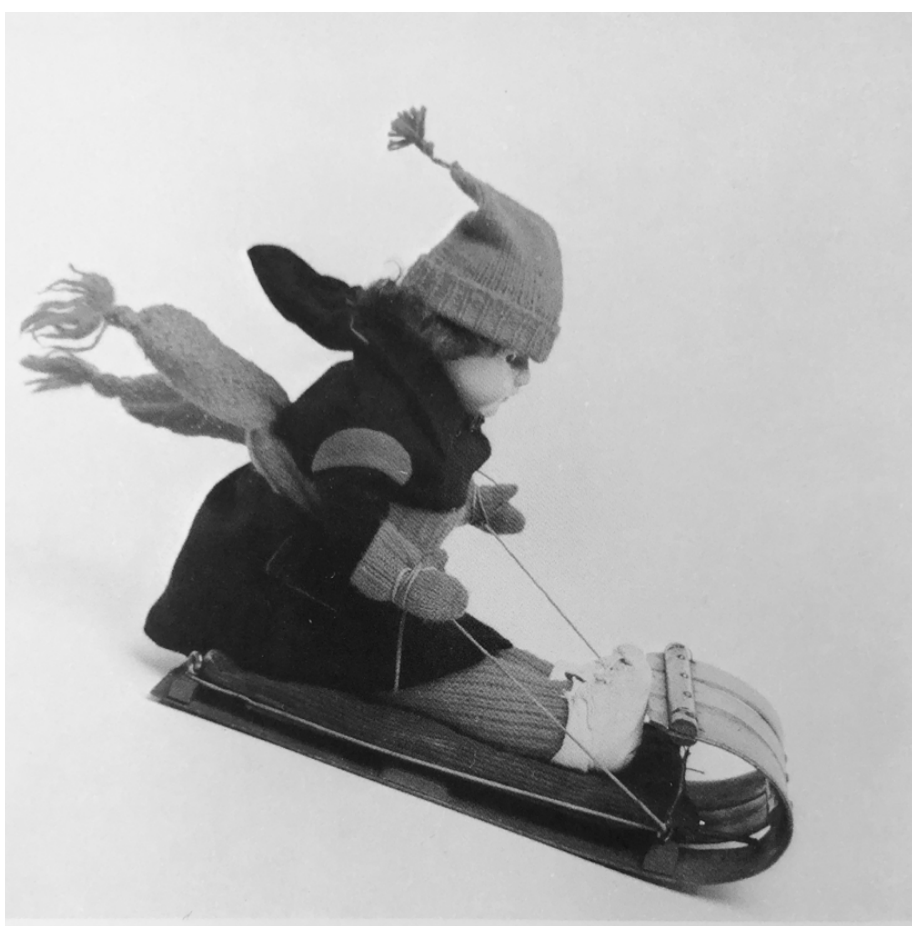

Almost all organized sport, as society knows today, developed during the industrial revolution in the nineteenth century. With more time for leisure, organized sport became an outlet to transcend the everyday from the ills of city life. The word 'sport' (c. 1400), derives from Old French desporter, "to divert, amuse, please, play; to seek amusement," literally "carry away" (the mind from serious matters), from des- "away" and porter "to carry," from Latin portare "to carry". During these years, the industrial revolution led to the rise of large cities and sport turned from something spontaneous into something organized. People simply wanted to sit and watch others play for entertainment. ${ }^{2}$ 
By the 1960 major sports had become spectator sports played by professionals for huge crowds in arenas and millions more in front of television screens, not unlike the roman spectacles held in the colosseum and circus maximus. ${ }^{3}$

Along with the political, social, and cultural similarities to the spectacles in ancient times, the production and sale of emotion plays a strong role in the economical success of sport. Sporting events elicit nostalgic recollections and strong emotions - "peak experiences" (unlike theatre or art) - because of the current demonstration of physical and psychic abilities of

4. Konstantin Lidin, "Between the Show and the War: Sports as a generator of emotions and architecture of sports venues," Project Baikal, no. 51 (March 31, 2017): 38-49 Pages, https://doi.org/10.7480/ PROJECTBAIKAL.51.1114., 40. a human being. ${ }^{4}$ This creates an attachment to and excitement about where one is and what they are doing in those moments.

Instead of diverting the mind from serious matters, can recreational infrastructure channel these moments to investigate the relationship between the health of humans and the environment? Athletic facilities attract people of different backgrounds and create opportunities to develop skills that transfer to other domains of social life. Social infrastructure and places where all kinds of people can gather not only enhances public health, but can also reinforce the goals of environmental sustainability and universal access. 
5. Exhibition wall text, Our Happy Life: Architecture and Well-Being in the Age of Emotional Capitalism, Canadian Centre for Architecture,

Montréal, Québec, 2019

6. Irene Cheng, ed., "Active Design Guidelines: Promoting Physical Activity and Health in Design" (Center for Active Design, 2010), https://centerforactivedesign.org/ dl/guidelines.pdf., 110.
Volunteering and the need to preserve the environment are two aspects that appear repeatedly in happiness reports as key practices to improve mental health, as works for a collective good are able to readjust personal levels of endorphins. ${ }^{5}$ Design strategies that increase physical activity and improve health—for example, measures that promote walking and cycling over driving, stair over elevator and escalator use, and active recreation over television watching-also tend to reduce energy consumption and greenhouse gas emissions. ${ }^{6}$ As these examples illustrate, a diverse, active, healthy population and a sustainable planet are interlinked.

For the purpose of ecological restoration and physical recreation, this architecture project reimagines the expropriation of an urban site that was once home to a great system of physical activity. The area known as Polo Park, in Winnipeg, Manitoba, was heavily researched to unfold the narrative of the former sports hub and its connection to the landscape. Once known as the 'Heart of the Continent,' Winnipeg was home to rapid urbanization at the turn of the twentieth century. As the city experienced accelerated transformation, civic leaders recognized the importance of recreation. Suburban parks were built to meet the rising citizen expectations for recreational lands. Polo Park, which is now a regional shopping district covered in concrete 
parking lots, was once a diverse and natural landscape. The wide river lot was preserved from cultivation because of Omand's Creek, which meandered through the site and into the Assinaboine River, creating an ideal destination for outdoor activity. The creek has since been transformed into a channelised waterway flowing through the sterile urban landscape.

The project embraces the sense of nostalgia from the site's history of city and country-wide sporting venues. Although its history reflects twentieth century ideas of competition in the global context of sport and fascism, the project does not reside in these issues, but rather the post-war sense of pride and cultural belonging these venues established. Space for leisure on the outskirts of the city became a meeting place drawing Winnipeggers from all backgrounds, social classes and ages. 


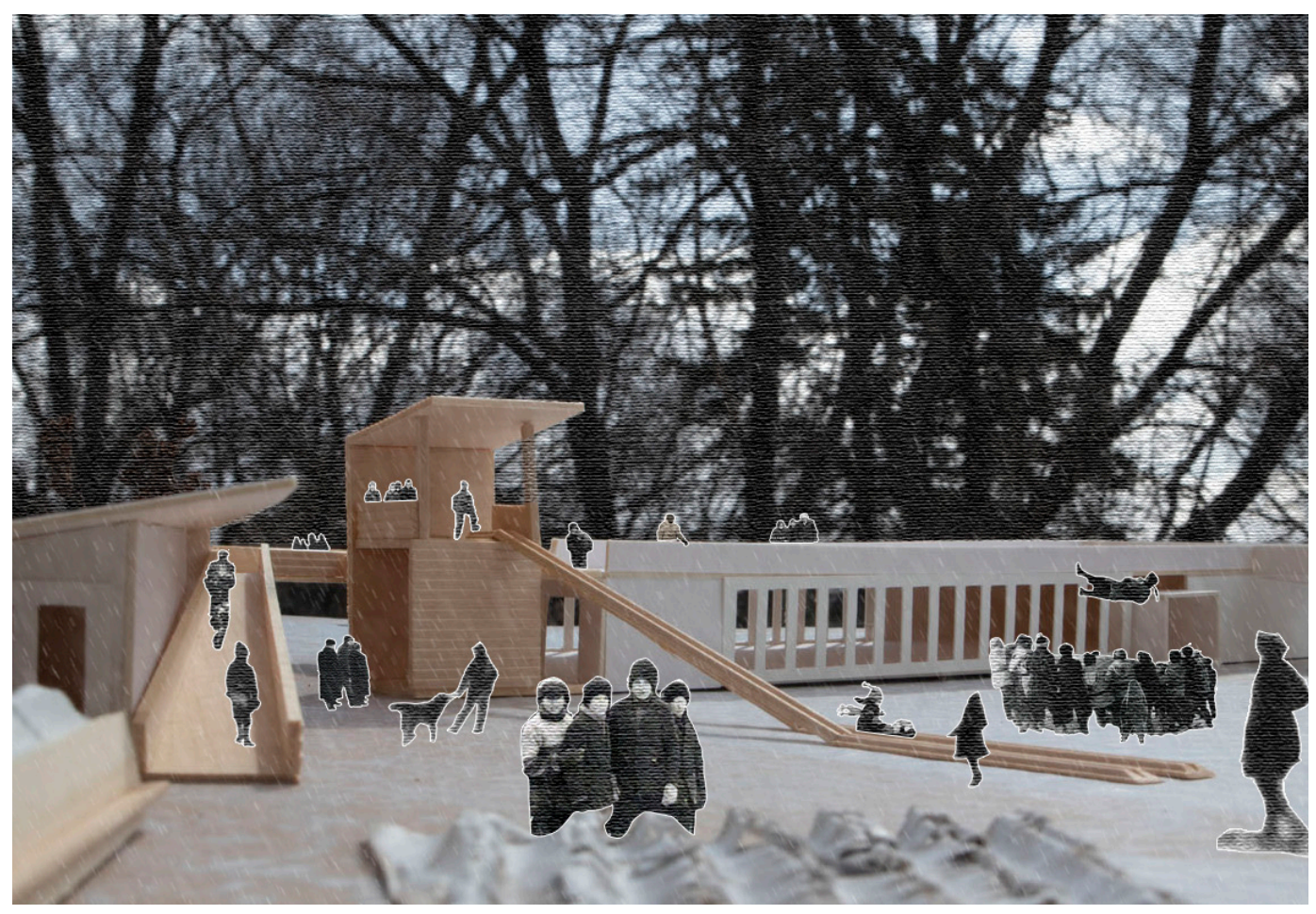

Figure 6. Final Model Perspective.

Through studies and explorations of the body's

relationship to the landscape, the project imagines

a place to gather, recreate, relax, learn, and enjoy the

seasons. The project aims to rehabilitate the relationship between humans and the environment, and perhaps aid in shaping a civic consciousness to maintain active and sustainable lifestyles. The work explores recreational infrastructure to support outdoor activity and restores elements of Winnipeg's vernacular as a starting point to the project's design. 
Chapter 1: Themes of Research 


\subsection{Lungs of the City}

7. Ralph C. Wilcox, ed., Sporting Dystopias: The Making and Meaning of Urban Sport Cultures, SUNY Series on Sport, Culture, and Social Relations (Albany: State University of New York Press, 2003), 2

8. Irene Cheng, ed., "Active Design Guidelines: Promoting Physical Activity and Health in Design" (Center for Active Design, 2010), https://centerforactivedesign.org/ dl/guidelines.pdf., 12.
Societies have used the design of the built environment to improve and maintain public health for centuries. As the modern city grew to improve access to production and consumption, the city experienced inevitable ills as overcrowding, crime, poor health and pollution at levels unwitnessed in rural life. ${ }^{7}$ Just as aqueducts were built to transport fresh water, sewage systems designed to dispose of waste properly, and setbacks to let light and air into the street; public parks provided breathing spaces for the "working man's lungs."

Sufficient open space outside cities became inaccessible to most of the public, and disease and discomfort prompted high population densities to provide accessible open spaces within the city. In 1933, members of the Congrés Internationaux d' Architecture Moderne (CIAM),

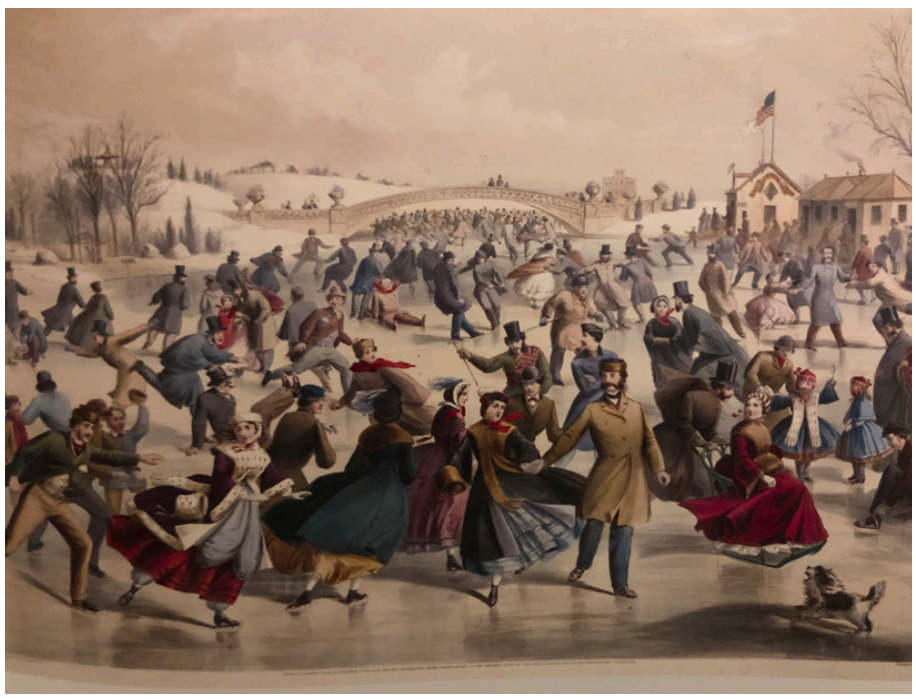

Figure 7. Currier and Ives, Central Park, Winter, The Skating Pond, 1862. 
9. John R. Gold, “Creating the Charter of Athens: CIAM and the Functional City, 1933-43," Liverpool University Press Vol. 69 , No. 3, no. The Town Planning Review (July 1998): 225.

10. Ibid, 230

11. Ibid, 236.

12. Le Corbusier, The Athens Charter (International Congress for Modern Architecture, New York: Grossman Publishers, 1973)

13. Wilcox, Sporting Dystopias, 3.

14. Irene Cheng, ed., "Active Design Guidelines: Promoting Physical Activity and Health in Design" (Center for Active Design, 2010), https:// centerforactivedesign.org/dl/ guidelines.pdf., 12. a multinational body of modern architects, gathered to address town planning issues. ${ }^{9}$ An exhibition and compiled analyses of cities within their own countries led to a document known as the 'Athens Charter,' which mapped out four key functions of the city: dwelling, work, leisure, and circulation..$^{10}$ Observations on 'leisure' pointed to the inadequate supply of green space and leisure facilities for most of the city's inhabitants; the need to protect green space by land use controls; and the possibility of using land reclamation to increase the supply of leisure space." The social point of view, which today gives new meaning to the use of these spaces, had not yet emerged. ${ }^{12}$

Various explanations have been attributed to sporting developments with the emergence of the industrial world, but perhaps the simple fact that as people left behind the open spaces of their rural lives for the cramped confines of the city, they demanded new arenas for the pursuit of those healthful physical pastimes that had become so central in their lives..$^{13}$ Today, most people spend as much as ninety percent of their days indoors. Office jobs, different forms of transportation, and online entertainment contribute to a sedentary lifestyle. ${ }^{14}$ Urban designers and architects can foster physical activity for the general public by designing spaces and streets that encourage walking, bicycling, 
and other forms of active transportation and

15. Ibid. recreation..$^{15}$ These opportunities not only enhance

public health and promote regular instances of physical activity, they also reduce the reliance on external forces of energy. 


\subsection{Promoting Urban Activity}

Figure 8. YMCA Fundraising pamphlet for the Tulsa, ca. 1909, Oklahoma.

\section{Give Him a Chance}

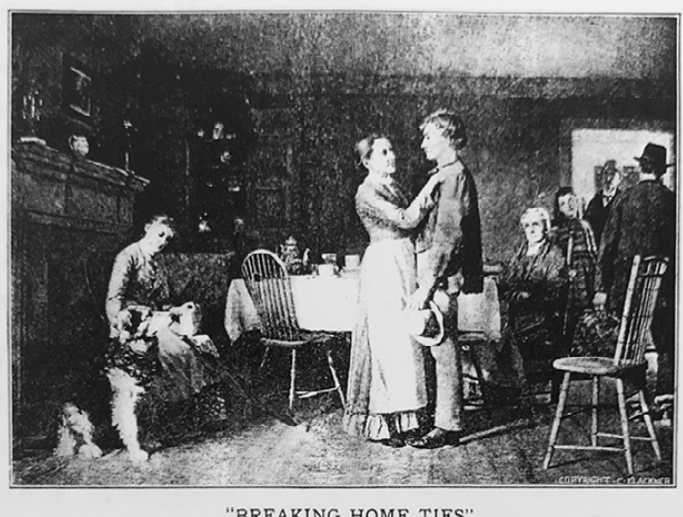

If He Landed in Tulsa TODAY Who Would Get Him?

\section{Y. M. C. A.---Not Yet Open Brothels Open---How Many?}

More than 900 young men live in the down town district

While environmental design strategies, in combination

with societal changes contributed to building a

healthy city, the rapid urban growth in North America

disregarded the scale of the individual making

physical activity difficult to achieve. Printed media

both reflected and contributed to widespread interest

in social and physical activity. As more young men

left their family farms for the big city, the social

aspects of club memberships formed to keep them

preoccupied and away from trouble. The Young Men's

Christian Association (YMCA) and the Young Women's 
Figure 9. Y.M.C.A. Building, 1907, Winnipeg.

16. Paula Lupkin, Manhood Factories: YMCA Architecture and the Making of Modern Urban Culture, Architecture, Landscape, and American Culture Series (Minneapolis: University of Minnesota Press, 2010), xvi.

17. Ibid.

18. Ibid.

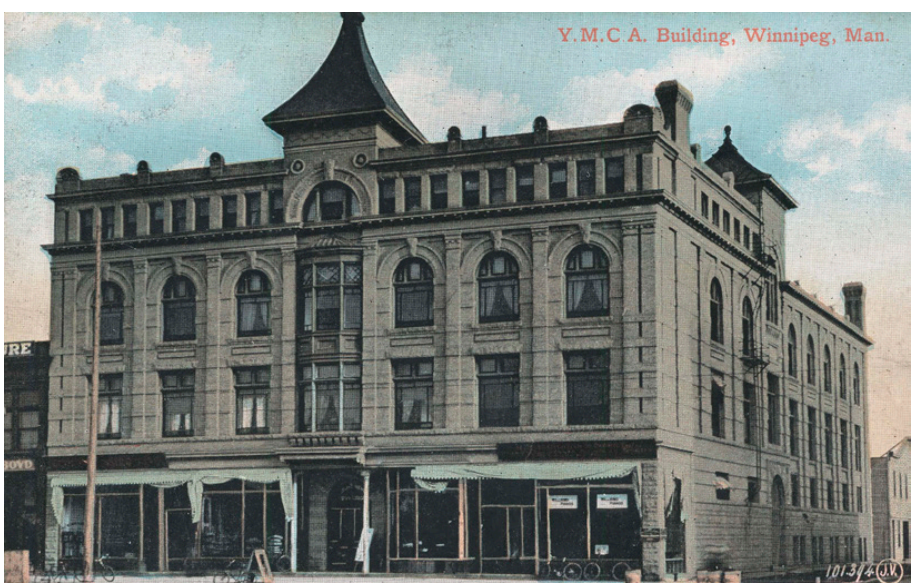

Christian Association (YWCA), became significant social organizations present in the urban fabric of every major city across North America and eventually worldwide. ${ }^{16}$ These standardized buildings intended to mass-produce properly socialized, practically educated and morally upright young men and women for the modern age, mediating the shift from an agrarian past to a corporate urban future. ${ }^{17}$ The traditional three or four-storey brick buildings with classicizing detail are so typical, but they have not gained much attention from architecture historians nor the subject of vernacular architecture. ${ }^{18}$ Built in response to economic growth and depression, these buildings on main streets consisted of leisure space and facilities to establish places for social uplift and education, which played a fundamental role in reshaping the post-war society.

In Canada, participation in the First World War reminded Canadians that military drill exercises in the nineteenth century were still relevant in schools and that organized sports prepared men and boys for the defence of their 
Figure 10. YMCA campaign clock at the corner of State \& Madison, 1908, Chicago.

Figure 11. YMCA campaign clock, ca. 1915, Foochow, China.

20. Don Morrow and Kevin B. Wamsley, Sport in Canada: A History, Third edition (Don Mills, Ontario, Canada: Oxford University Press, 2013), 6.

21. Ibid.

23. Ralph C. Wilcox, ed., Sporting Dystopias: The Making and Meaning of Urban Sport Cultures, SUNY Series on Sport, Culture, and Social Relations (Albany: State University of New York Press, 2003).
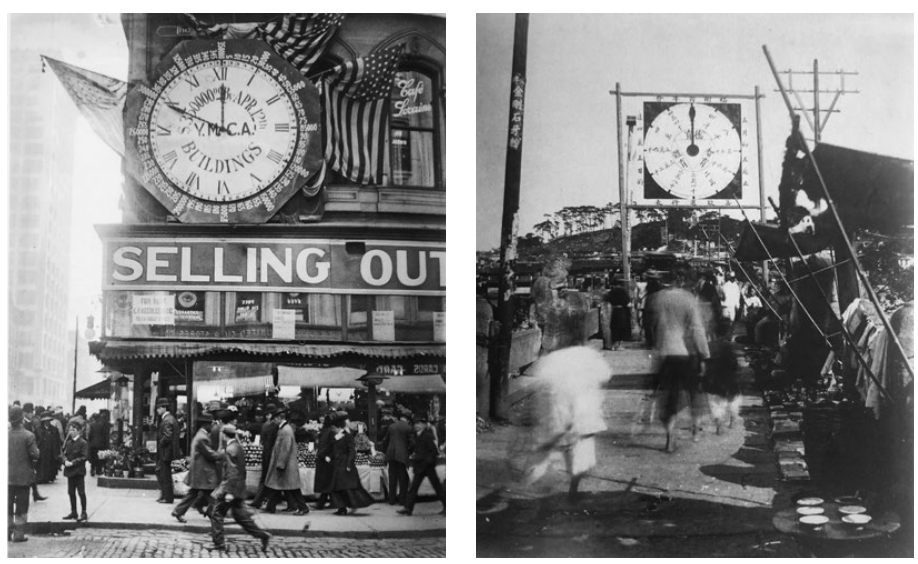

nation. ${ }^{20} \mathrm{~A}$ post-war sense of pride reaffirmed that trained bodies were indications of a nation's progress.

By the turn of the century, Canada looked outward to test itself more frequently in international competition. ${ }^{21}$ The Olympic Games offered the primary outlet for athletes, just as the world's fairs and expositions of the day which measured Canada's success in manufacturing, mineral excavation and agricultural production. ${ }^{22}$

Architects, engineers and designers attempting to regenerate and rejuvenate cities after World War II were aware of popular interest in competitive sports. ${ }^{23}$ Parks and stadia were intended to help erase negative urban images and became icons of newborn societies. 
"Sport has the power to change the world. It has the power to inspire, it has the power to unite people in a way that little else does. It speaks to youth in a language they understand. Sport can create hope, where once there was only despair. It is more powerful than governments in breaking down racial barriers. It laughs in the face of all types of discrimination." 


\subsection{Arena of the World}

Figure 12 . [German Olympian, Luz Long, befriends Jesse Owens at the 1936 Berlin Olympic Games in Nazi Germany]

24. United Nations, “Transcending Borders, Sport Plays Critical Role in Overcoming Hurdles to Building Peace, Sustainable Development, Speakers Tell General Assembly," Meetings Coverage, General Assembly, December 6, 2016, https://www.un.org/press/en/2016/ gall867.doc.html.

25. Nikolaus Katzer, "Introduction: Sports Stadia and Modern Urbanism," Urban History 37, no. 2 (August 2010): 249-52, https://doi. org/10.1017/So963926810000337, 249 .

26. Eric Klinenberg, Palaces for the People: How Social Infrastructure Can Help Fight Inequality, Polarization, and the Decline of Civic Life, First Edition (New York: Crown, 2018), 166.

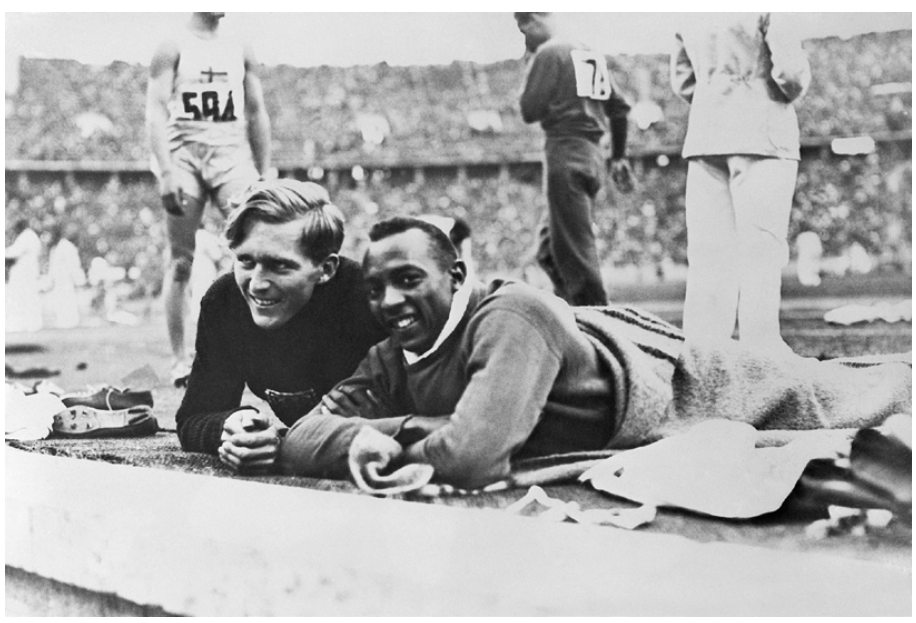

Sport has been used to advance peace and reconciliation and has the power to transcend borders. ${ }^{24}$ It can inspire all, regardless of age, race, ethnicity, religion, gender, or social class. Despite the fact that sporting spaces reflect key shifts in thinking about town planning, sports architecture is still an underexplored area in the historiography of urban design. ${ }^{25}$ Athletic facilities attract people of different backgrounds into a shared social space, allowing for competitive, playful, often joyous activity, and sparking relationships that would never have formed off the field or court. ${ }^{26}$ With sport and the city upheld as expressions of progress, hosting an Olympics became the ultimate symbol of modernity.

Despite the centuries that had elapsed since the Roman Emperor Theodosius I had prohibited the Olympic festival in $393 \mathrm{AD}$, knowledge about the Olympics and 
27. John R. Gold and Margaret M. Gold, eds., Olympic Cities: City Agendas, Planning and the World's Games, 1896-2020, Third edition, Planning, History and Environment Series (London; New York, NY: Routledge Taylor \& Francis Group, 2016), 21.

28. Ibid, 23.

29. Alison Steinbach. Competition, Cooperation, and Cultural Entertainment: The Olympics in International Relations, (Harvard International Review, Vol. 37, no. 2, Winter 2016): 39.

30. Gold and Gold, Olympic Cities, 435. its significance for ancient Greek society had never fully faded from European consciousness. ${ }^{27}$ The rediscovery of Olympia in the late eighteenth century aroused excitement beyond archaeological circles, as historians and other scholars eagerly devoured news emerging from Olympia. ${ }^{28}$ Like many aspects of ancient Greek society, scholars in the late nineteenth century saw achievements of the past as offering parallels for the modern age, which eventually lead to the Revival of the Olympic Games in modern times.

While the spirit of the Olympics has aimed to create international exchange, understanding and unity, the Games have recently become more political, commercial, and expensive - less about international cooperation and more about a host's political purposes or global competition. ${ }^{29}$ With the industrial age in the past and the world entering the advanced information age as a mature society, future Olympic hosts have an opportunity to refashion the 21st-century city while still achieving the Olympic legacy. ${ }^{30} \mathrm{~A}$ legacy that is not only about athletic facilities, but also related facilities, urban development and social evolution. Developments suggest that cities around the world are pursuing a more holistic approach to urban planning that integrates concerns about welfare, education, economy and the environment, speaking less about urban planning and 
Figure 13 . Victoria Skating Rink, 1863, Toronto.

31.Ibid.

32. Dunbar and MacLennan, Images of Sport in Early Canada,

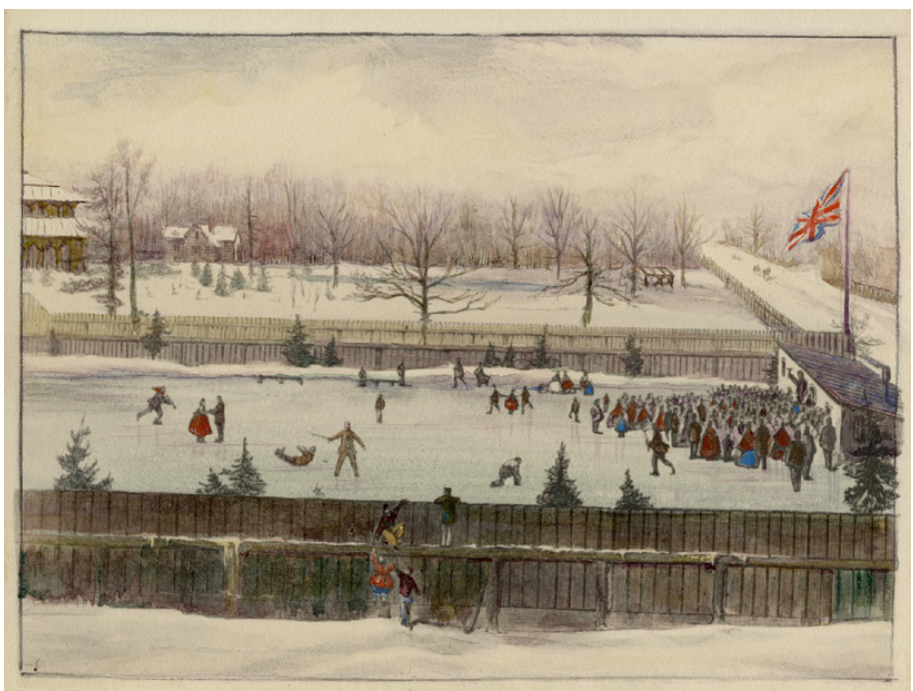

more about community development, spatial planning and smart growth. ${ }^{31}$ Sports and entertainment venues have and continue to produce the latest structural advances in architecture and construction on a massive scale. What if those efforts and infrastructure focused on smaller-scale projects for supporting community recreation? Not for the spectacle, but for the amateur athletes being watched by neighbours and friends, playing their games merely because they love them. ${ }^{32}$ 


\subsection{Fields of Knowledge}

Figure 14. W.C. Chewitt and Co., Lacrosse, 1856-70, lithograph, Toronto.

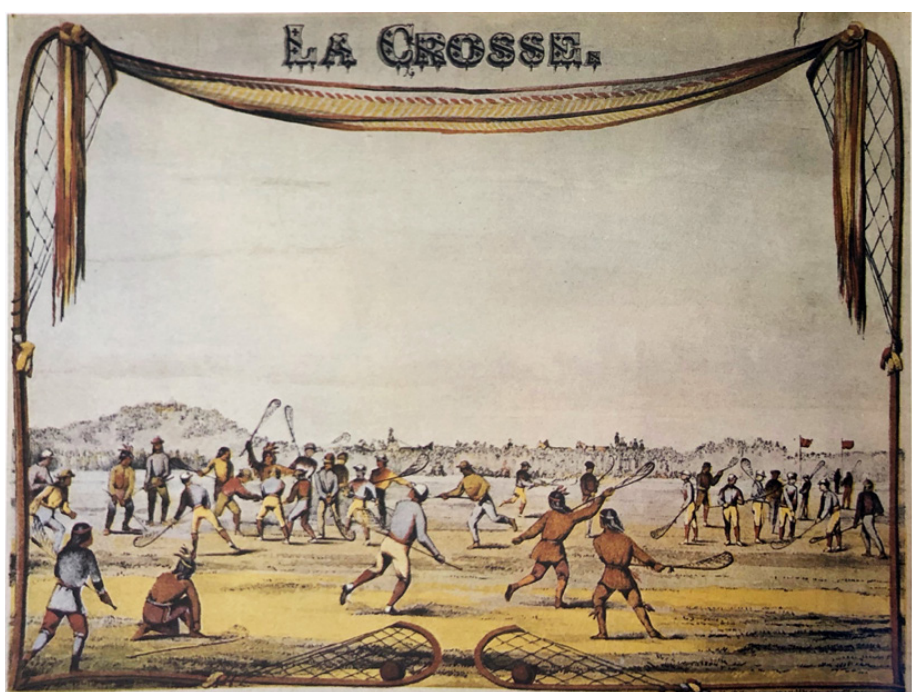

Diversity and teamwork can positively affect the social and public lives of a community. Access to shared, public and freely accessible social spaces that encourage diverse use and welcome diverse users can help facilitate social cohesion and trust. ${ }^{33}$

Generations of people within the modern boundary of Canada competed with one another and actively engaged in cultural forms - from farmers' games to rodeos to feats of strength - that came to be known and celebrated as sport. ${ }^{34}$ Similarities in how people a century ago related to one another through physical activity and common notions about the body remain significant even in today's society ${ }^{35}$ Nevertheless, attitudes toward the body differed. First Nations viewed the body as spiritually and physically significant in terms of survival, skill, and a sense of dedication to community life and 
36. Ibid.

37. Eric Klinenberg, Palaces for the People: How Social Infrastructure Can Help Fight Inequality, Polarization, and the Decline of Civic Life, First Edition (New York: Crown, 2018), 167.

38. Ibid.

39. Hebe Schaillée, Reinhard Haudenhuyse, and Lieve

Bradt, "Community Sport and Social Inclusion: International Perspectives," Sport in Society 22, no. 6 (June 3, 2019): 885-96, https:// doi.org/10.1080/17430437.2019.1565 380,888 . responsibility. In contrast, Europeans' different senses of survival skills and competitive practices altered these sports. Notions of masculine honour became enshrined in practice and celebrated through competition. ${ }^{36}$ Although they recognized the level playing field, European domination consequently homogenized diverse native cultures into a uniform collective.

Athletic fields can be places where social and political hierarchies lose their significance. The great anthropologist Victor Turner referred to such places as "anti-structural," because they allow people who might otherwise be hostile to one another play together in an experience he calls communitas: a liminal moment when all participants have the same social status and forbidden social bonds are suddenly encouraged. ${ }^{37}$ Sociologists have also found that participating in organized sports teams increases social capital, and learning to lead or work with teammates on the field helps players develop skills that transfer to other domains of social life. ${ }^{38} \mathrm{~A}$ critical approach to community sport highlights the need for society to recognize the very different ways of being human and can be distinguished in four concepts of inclusion: normative, integrative, dialogical and transgressive. ${ }^{39}$ To compare the extremes, normative approaches of inclusion focus on the active assimilation and normalization of minority 
40. Ibid, 889

41. Klinenberg, Palaces for the People, 11 . individuals to a dominant cultural standard;' whereas, in the transgressive conception of inclusion, the individual diversity is "used as a vehicle for the generation of new knowledge and learning experiences. ${ }^{\prime 40}$ Moments of interaction on the field help divided groups recognize their common humanity and can celebrate differences while empowering individuals. ${ }^{41}$ 


\section{Is sustainability a personal pursuit or a collective affair?}

Exhibition wall text, Our Happy Life: Architecture and Well-Being in the Age of Emotional Capitalism, Canadian Centre for Architecture, Montréal, Québec, 2019. 
Chapter 2: Site 
"The white man always

attempted to avoid

the snow or skirt it,

whereas the Indian

always looked for the

best way to walk on it

and live in harmony

with nature."

First Nation knowledge passed down

from generation to generation
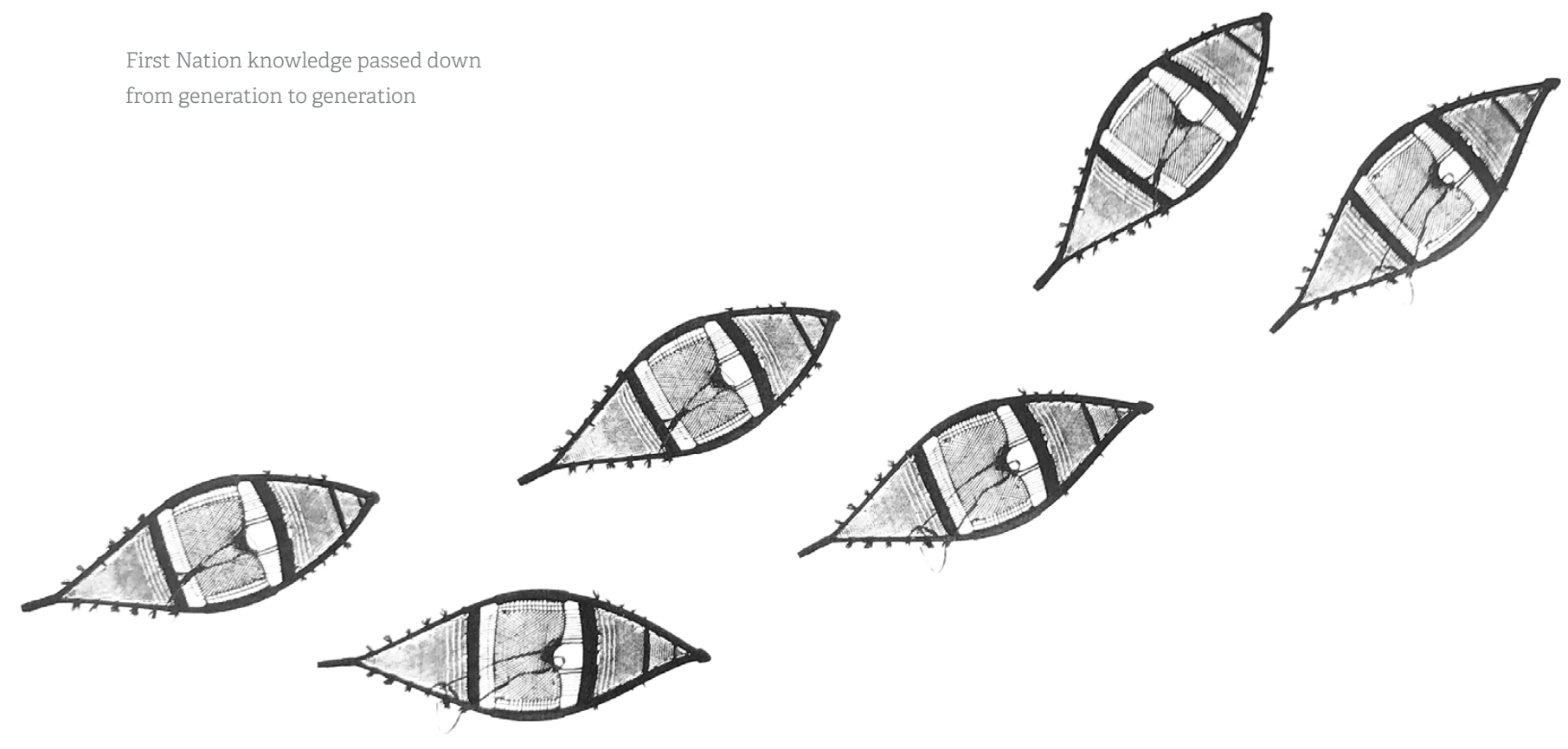


\subsection{Heart of the Continent}

Figure 16 . Group of immigrants arriving at CPR Station, 1927, Higgins Avenue and Main Street Winnipeg.

42. “Winnipeg," Canadian

Encyclopedia, accessed

March, 2020,https://www.

thecanadianencyclopedia.ca/en/

article/winnipeg.

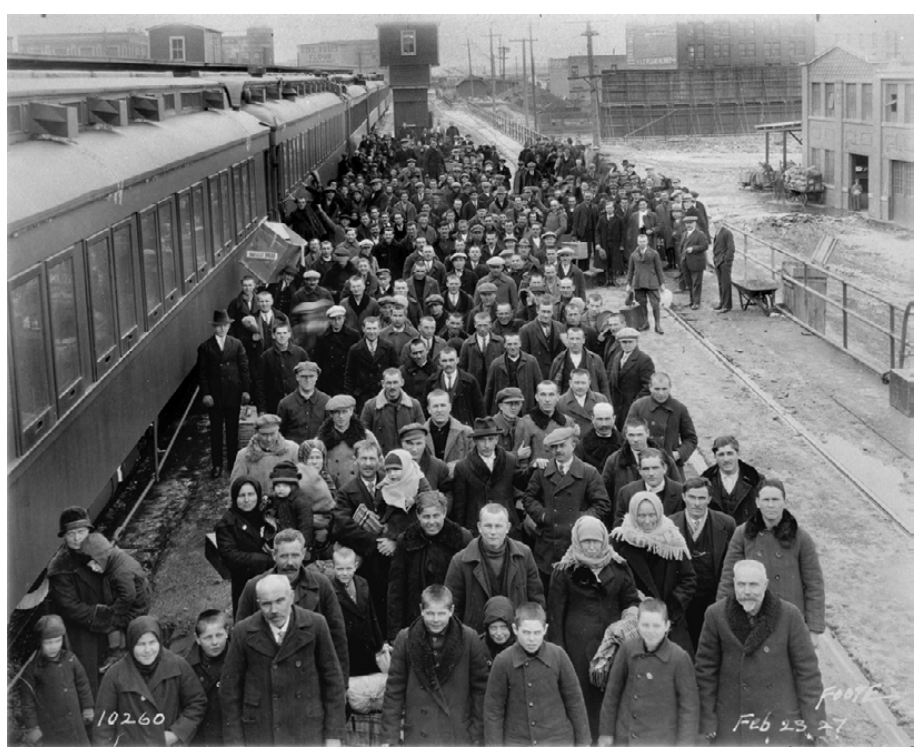

Known as the "Gateway to the West," the City of

Winnipeg is a prime example of rapid urbanization.

Its strategic location made it the epicentre for the transcontinental railway extension to the west. After the completion of the Canadian Pacific Railway in 1885, the city's period of growth was unparalleled in Canadian development. Growing from a population of 20,000 in 1886 to 150,000 in 1911, it became the third-largest city in Canada at the start of the twentieth century. ${ }^{42}$

This rapid urban growth brought prosperity and accelerated transformation to the city's urban fabric, but outpaced the expansion of the city's park system. With most cities in North America creating parks in their masterplans, Winnipeg aimed to do the same. As one of the first cities in Canada to recognize the importance of 
43. Catherine Logan Macdonald, Winnipeg (Man.), and Parks and Recreation Department, A City at Leisure: An Illustrated History of Parks and Recreation Services in Winnipeg 1893-1993 (Winnipeg, MB: City of Winnipeg, Parks and Recreation Dept., 1995), v.

44. David Spector, Assiniboine Park: Designing and Developing a People's Playground (Winnipeg MB: Great Plains Publications, 2019), 11.

45. Ibid, 48 .

46. Ibid, 11 recreation, the city is acknowledged as a leader in the development of beautiful parks, innovative facilities and a full complement of recreation programs and services. ${ }^{43}$

Large suburban parks were built to meet the rising citizen expectations for recreational lands. Assiniboine Park, in particular, has provided an idyllic escape from the hustle and bustle of city life for more than 100 years. ${ }^{44}$ The park covers two hundred and eighty acres, featuring a run of prime Assiniboine River frontage. ${ }^{45}$ It has reflected the evolution of Winnipeg and its societal values transforming from a pleasure playground oriented to relaxation, contemplation and family recreation, to a twenty-first-century theme park at the forefront of popular botanical and zoological education and Indigenous teachings. ${ }^{46}$

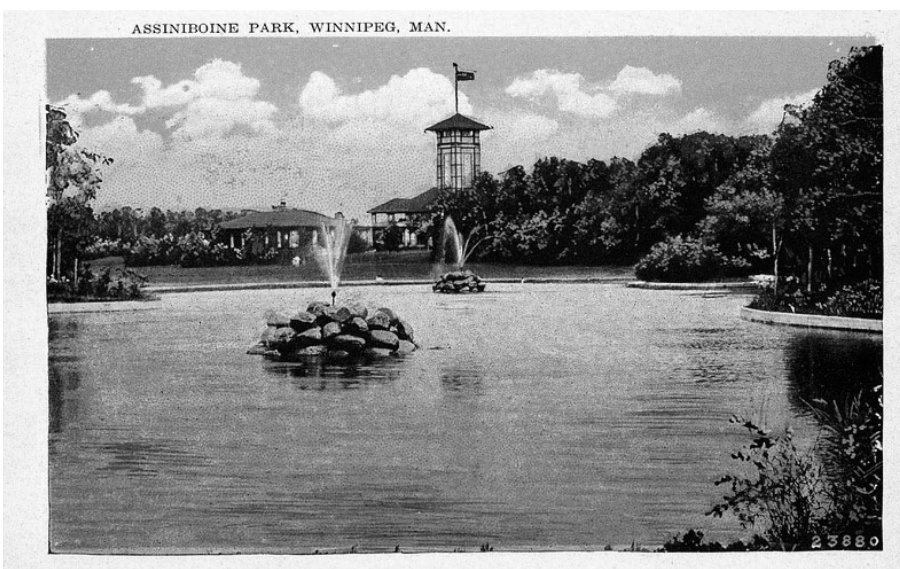


47. Catherine Logan Macdonald, Winnipeg (Man.), and Parks and Recreation Department, A City at Leisure: An Illustrated History of Parks and Recreation Services in Winnipeg 1893-1993 (Winnipeg, MB: City of Winnipeg, Parks and Recreation Dept., 1995), 31.

48. Ibid.
From its conception, sports and active recreational uses within the park were reluctantly included. Winnipeg's Superintendent of Parks, George Champion, was particularly worried that the pressures on the board to place playing fields and playgrounds in neighborhood parks would result in the destruction of these areas as passive green spaces, and thought baths and gymnasiums might be best accommodated in the new collegiate institutes or in "community centres" then being experimented within the United States..$^{47}$ It took several decades to provide the recreational services that the people of Winnipeg were increasingly demanding. ${ }^{48}$ 


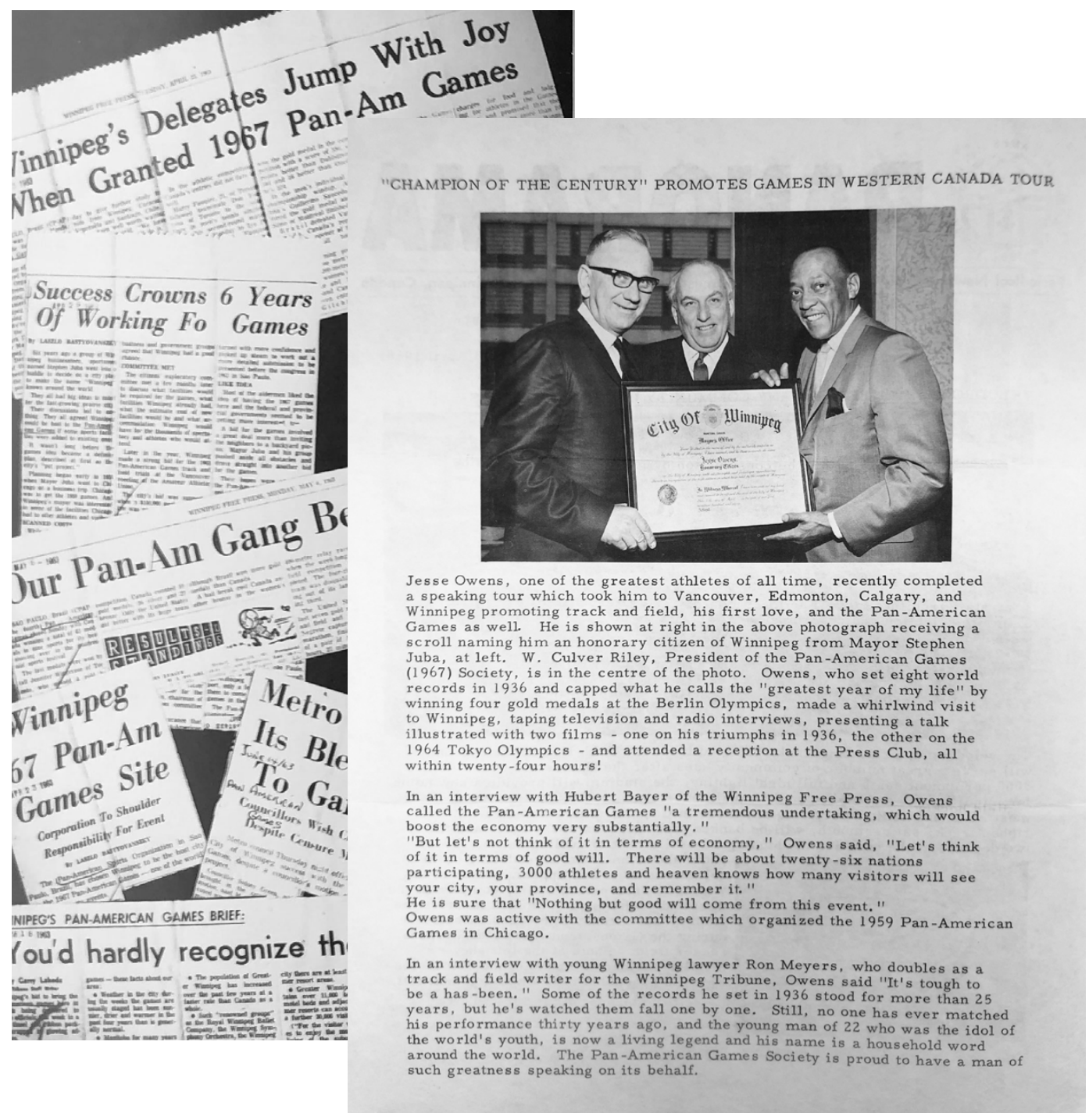

\section{"But let's not think of it in terms of economy. Let's think of it in terms of good will."}




\subsection{Polo Park}

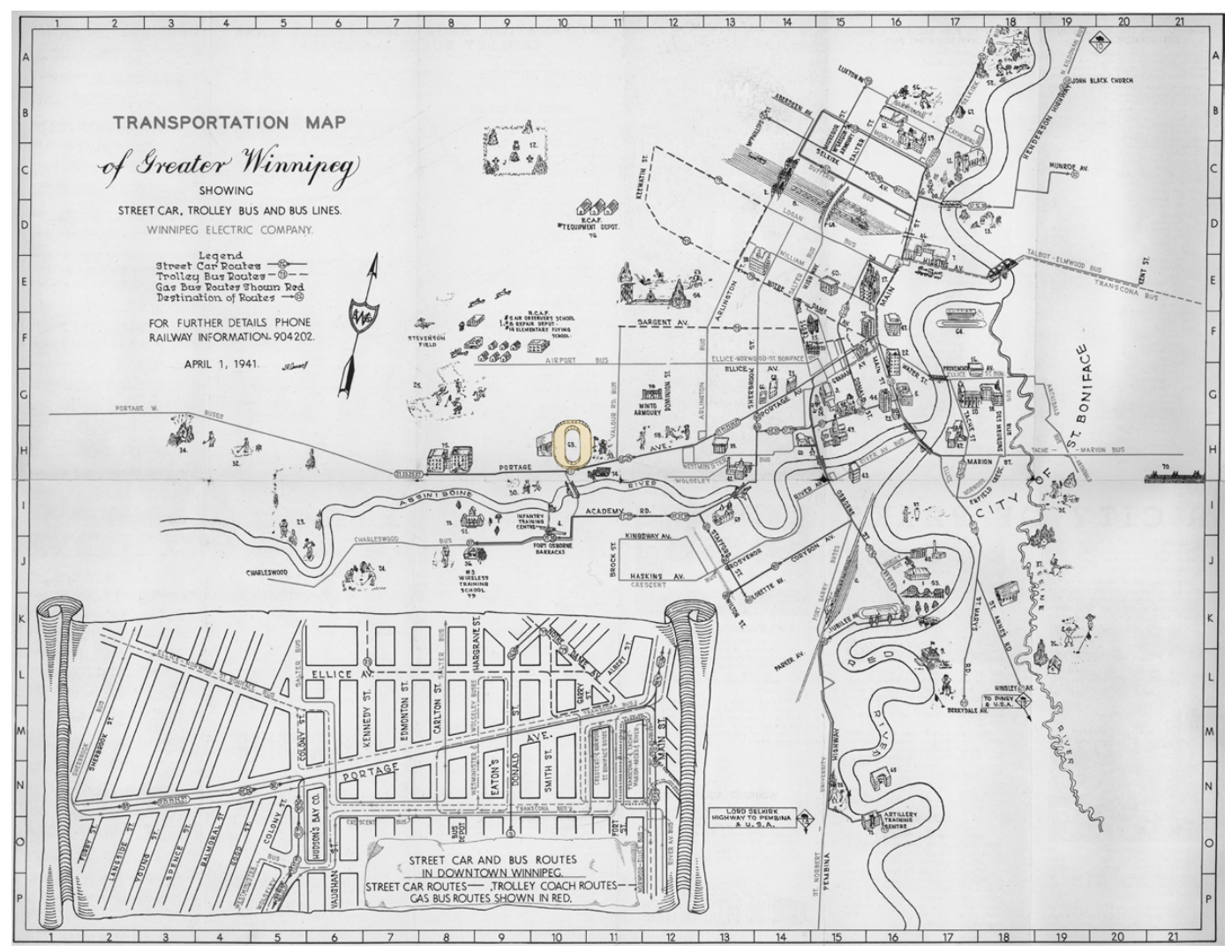

Figure 20. Transportation Map of Greater Winnipeg, 1941.

\section{Polo (noun)}

Etymology: Balti Tibetan polo ball (cognate with Lhasa Tibetan pulu, Lhodra Tibetan poli, Dzongkha bôli )

English ball

-Oxford English Dictionary
The site for the proposed project is located in the city's major shopping district known to Winnipeggers today as "Polo". It's namesake is from the Polo Park Racetrack that once existed on site. At the time, the racetrack was located on the outskirts of Winnipeg. As an activity, polo was intended to train the dexterity of soldiers on horseback, and is one of the world's oldest known team sports. Although no record of polo was ever played on site, the area was once known as the city's sports hub. 


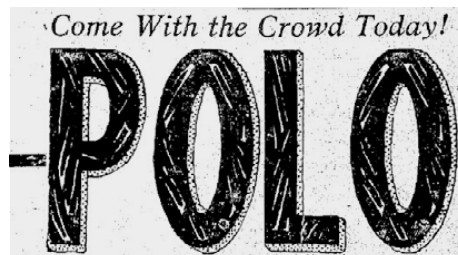

Seven Races Every Day
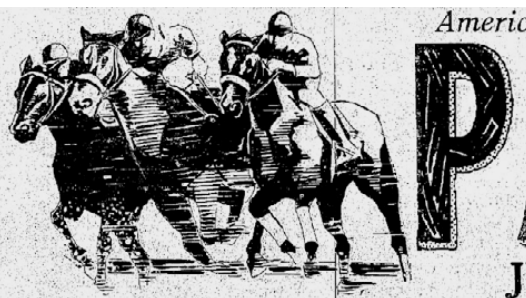

JUNE 12 to 19

TWO \$80 0.00 PURSES ON SATURDAY Comfort and Convenience for All--No Mud

Rain or ? hine

PARI-MUTUEL SYSTEM

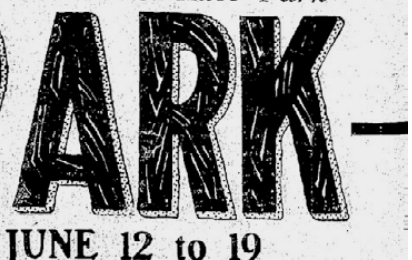

Admission $\$ 1.50$ Inctudes Grand

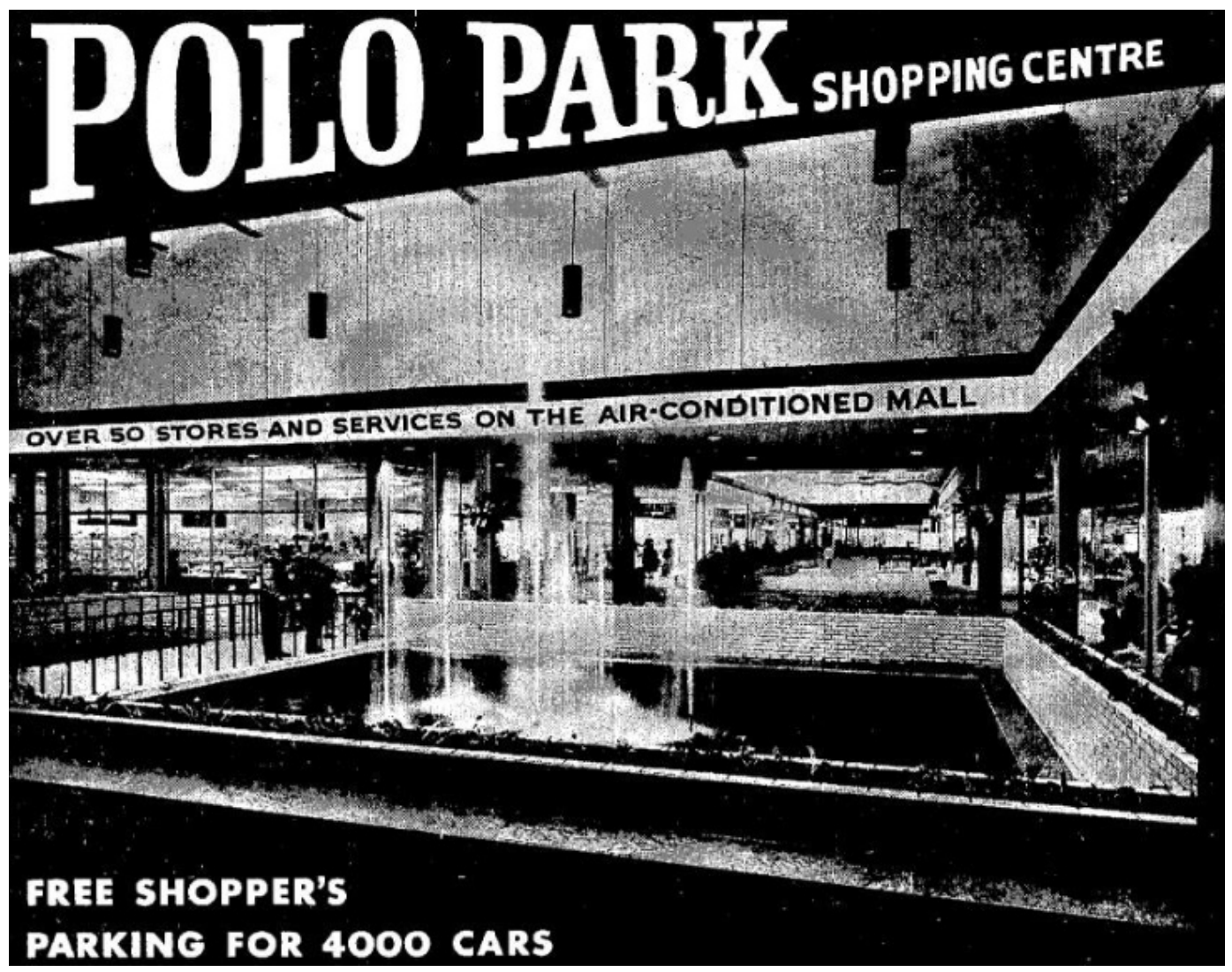

Figure 21. Polo Park advertisement, 1925, Winnipeg Free Press

Figure 22. Polo Park Shopping Centre advertisement, 1959
The project builds from the important site history and the strong framework of recreation that once existed. 


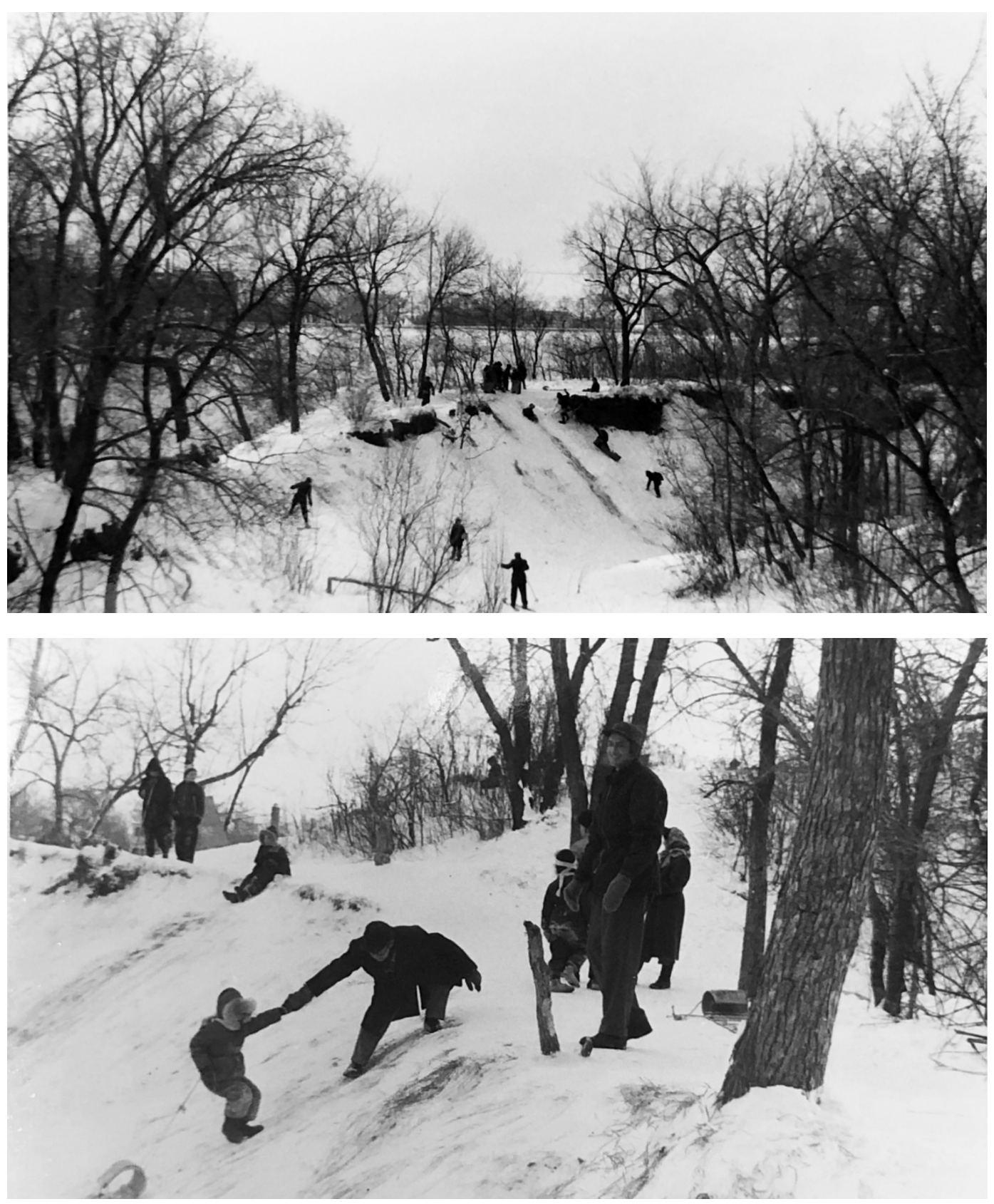

Figure 23. Outdoor activity at Omand's Creek, ca. 1960.

Figure 24. Tobogganing at Omand's Creek, ca. 1960.
The area was originally chosen as a place for physical activity because of its natural landscape. The creek on site meandered and carved the land, preventing cultivation of the area, but provided a desirable destination for outdoor activity. 
Figure 25. Plan of River lots in the parishes of St. John, St. James and St. Boniface, 1874.

Figure 26. T. Eaton Company Store in Portage Avenue, Winnipeg.

Figure 27. Eaton Park Place Golf Course surrounding Polo Park Racetrack.

49. Eileen Pruden, “The Other Polo Park," Winnipeg Real Estate News, April 28, 1989.

50. Ibid.

51. "Eaton's Department Store fonds," accessed March 2020 https://umanitoba.ca/libraries/ units/archives/collections/rad/ eatons.html
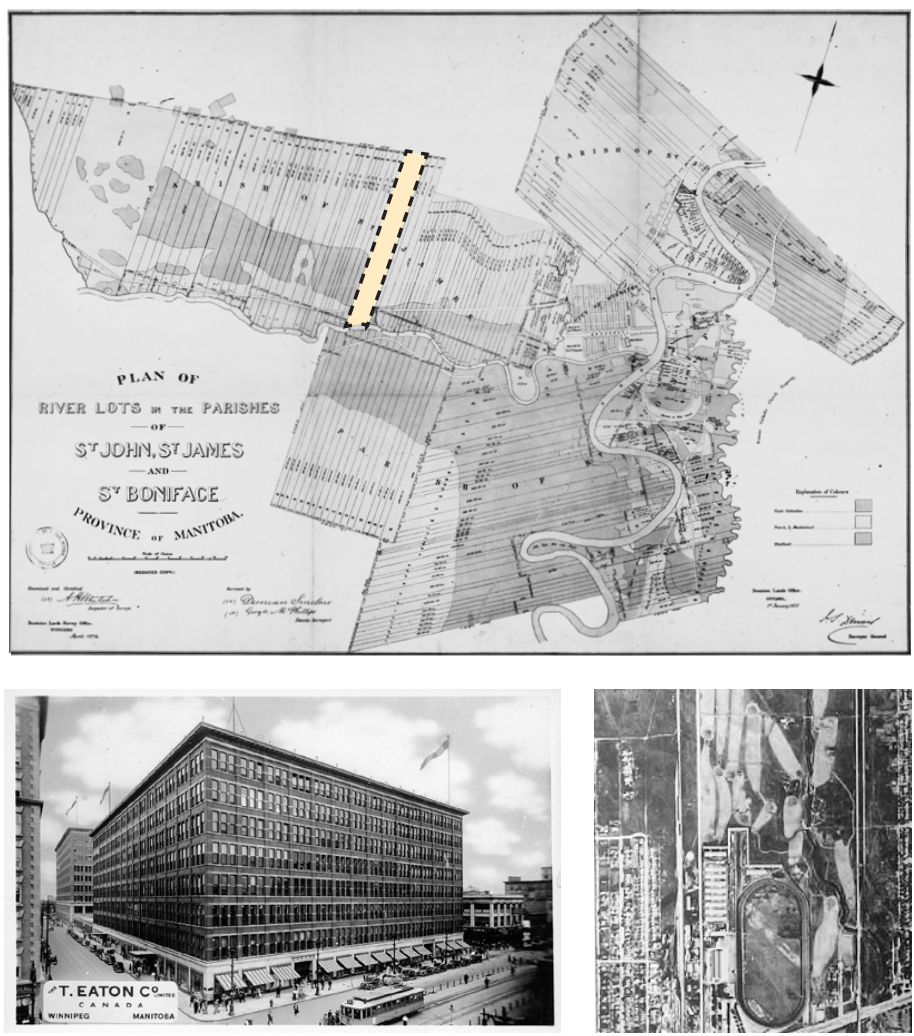

Since the early 1800 , the area was in constant use as a pasture because of the lush grass and woods situated on the property. ${ }^{49}$ In 1850 , the land west of the creek meandering through the site was granted by the Hudson's Bay Company for the St. James Church and Cemetery, which was built at the south end of the river lot. The natural landscape outside the city at that time, became the ideal place for the T. Eaton Company to rent 10 acres of land in $1910 . .^{50}$ For many years, the Winnipeg Eaton's store became the most successful outlet in Canada, given how it dominated its local market. ${ }^{51}$ Timothy's son, John Craig Eaton, who saw Winnipeg's successful location to serve its western customers, was also an advocate for physical fitness through sport. He built an athletic ground for his 3000 employees and 
Figure 28. Polo Park Postcard, 1956.

Figure 29. Victory Gift in the Polo Park Winner's Circle, 1948.

52. Ibid.

53. Keith Wilson and Antoine S Lussier, Off and Running: Horse Racing in Manitoba (Winnipeg: Peguis Publishers, 1978), 31.
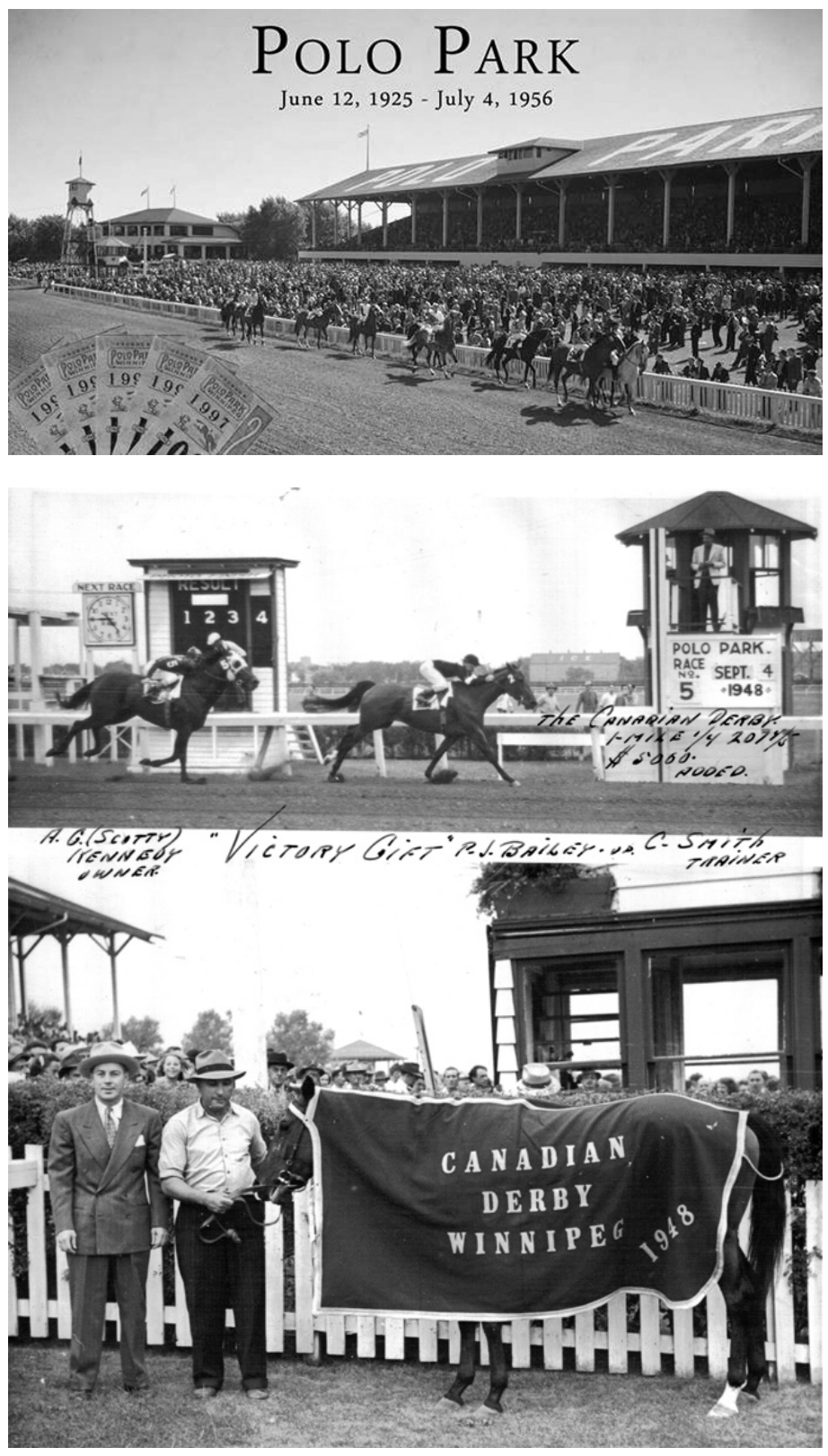

named it Eaton Park Place, which was in use until 1914 when many male employees joined the armed forces and fought in the first World War.52 In 1925, R. James Speers, "the guiding genius behind western Canadian thoroughbred racing," ${ }^{53}$ built the Polo Park Racetrack just north of Portage Avenue. At the time, the six-furlong track was considered one of the finest in western Canada and was home to the Canadian Derby until it 
Figure 30 . Drawings for Polo Park Shopping Centre, Winnipeg, 1958.

Figure 31 . Aerial view of Polo Park Shopping Centre, ca. 1960, Winnipeg.

Figure 32 . View to SimpsonsSears, with sculptural Sundial Jim Willer and Duane Eicholz, ca. 1959 .

Figure 33. George Swinton's Acrobats (Concrete), ca. 1959.

54. Jeffrey Thorsteinson, Brennan Smith, and Winnipeg Architecture Foundation, GBR: Green Blankstein Russell and Associates : An Architectural Legacy, 2017, 100.

55.Ibid, 1.
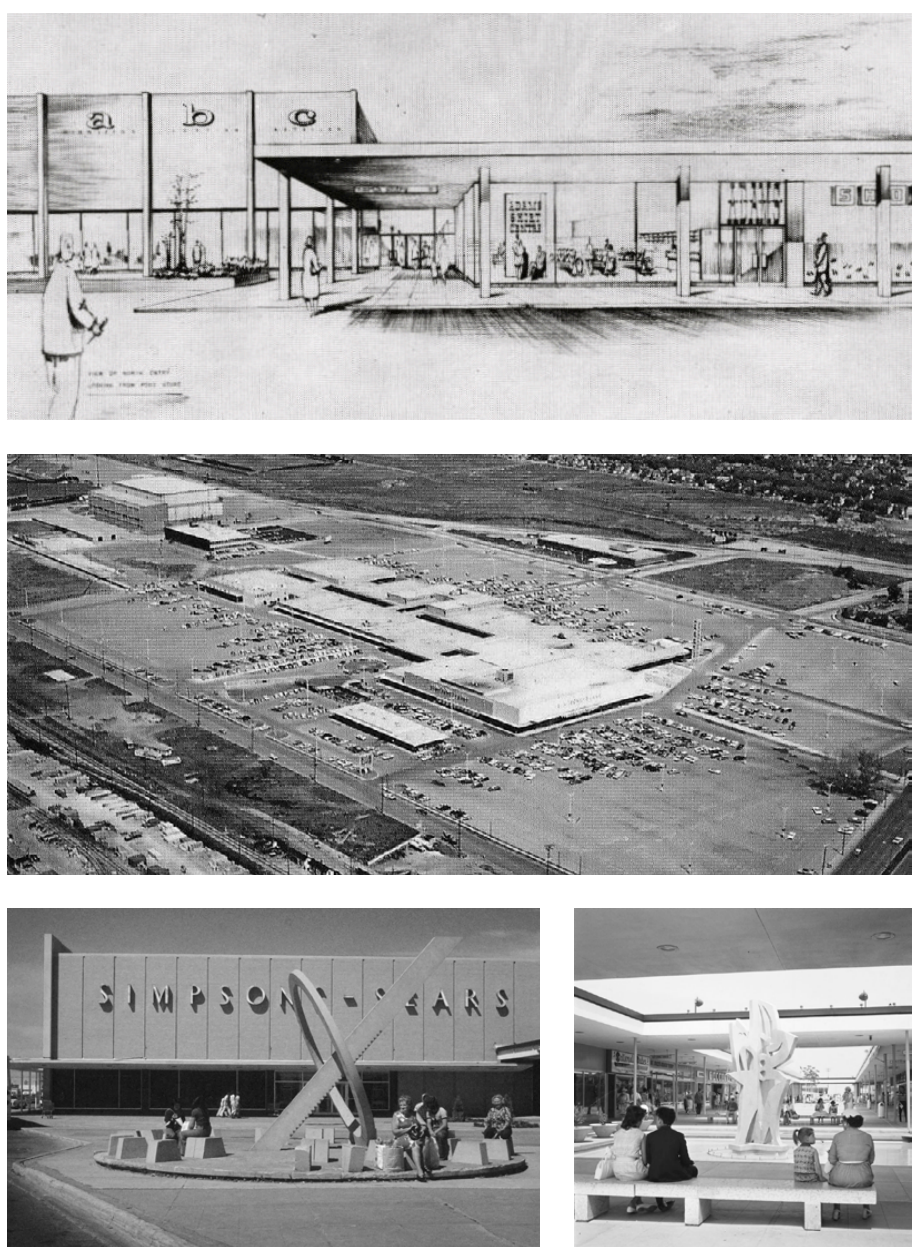

moved to Edmonton in 1955. When Speers passed in 1955, the land was sold and Polo Park Shopping Centre was built in 1959. A year after America's first shopping mall opened, designed by Austrian-American architect Victor Gruen, "the father of the shopping mall," the architecture practice of Green Blankstein Russell started the design of the Polo Park shopping plaza. ${ }^{54}$ This visionary firm shaped Winnipeg's urban landscape and the architectural industry with their novel interdisciplinary approach that included architects, engineers, interior designers, planners, women and minority groups. ${ }^{55}$

Diversity and teamwork was integral to their success and their innovations were later adopted by others. 
Figure 34 . Polo Park Mall Postcard, ca. 1963

Figure 35. Aerial Photograph of Polo Park area, ca. 1980, Winnipeg.

Figure 36 . Canad Inns Stadium Figure 37 . Line up for Jets tickets, 1978, Winnipeg Arena.

56.Ibid, 100
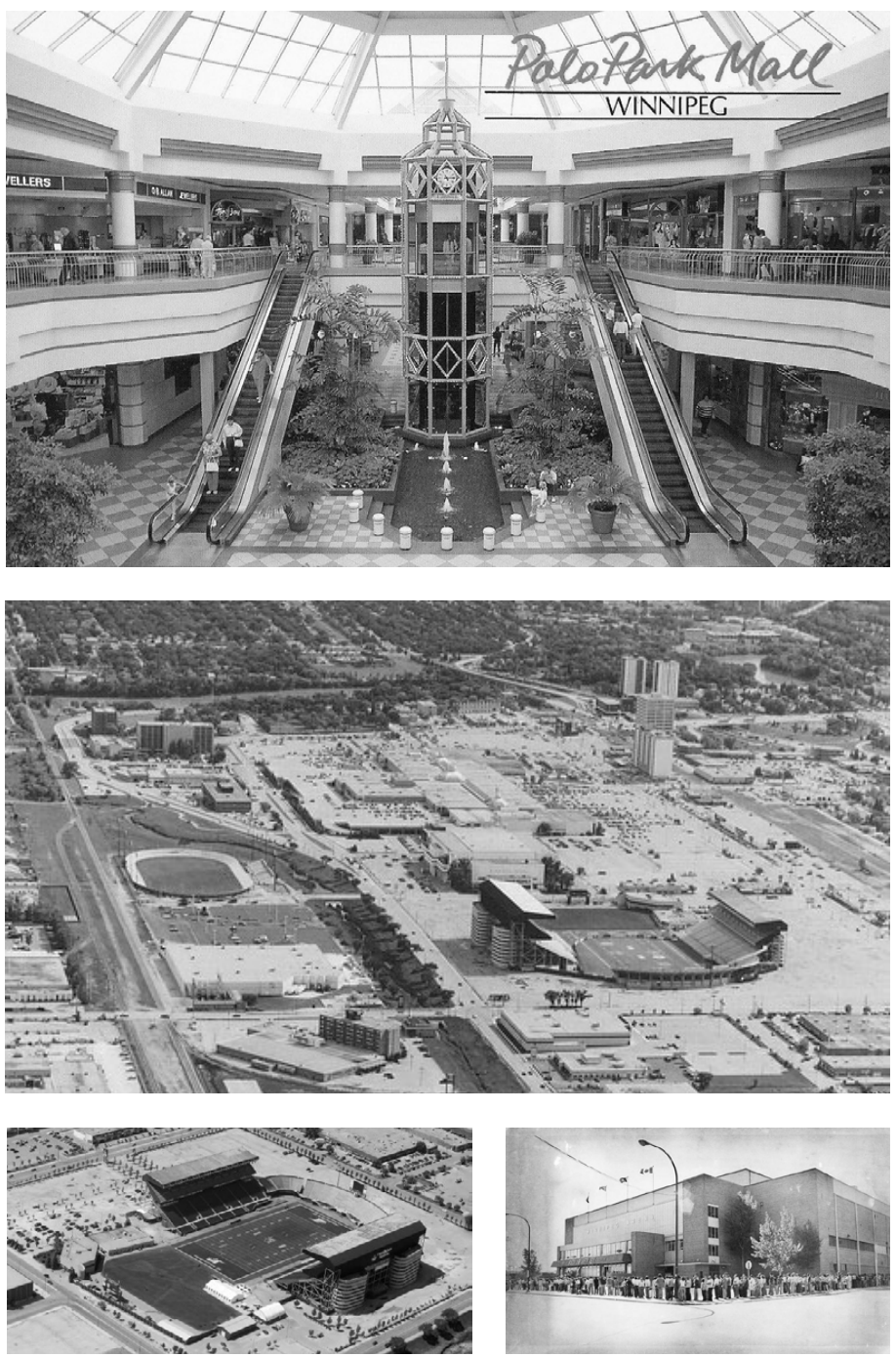

In 1963, Polo Park Shopping Centre became one of the first enclosed shopping malls in Canada when a roof was added to the second floor, ${ }^{56}$ becoming the climatecontrolled mall Gruen grew to regret. Built adjacent to the shopping mall, the Canad Inns Stadium (1953-2013), Winnipeg Arena (1955-2006), Alexander Park and the 1967 Pan-American Games Velodrome (1967-1991) have been home to major sporting events in the city. Although each venue has since been demolished and relocated, the memory of a sports hub still remains. 
Figure 38. Target Polo Park, 2015.

Figure 39. Bluestem Nature Park, 2019.

Figure 40. Garbage Hill, 2020.
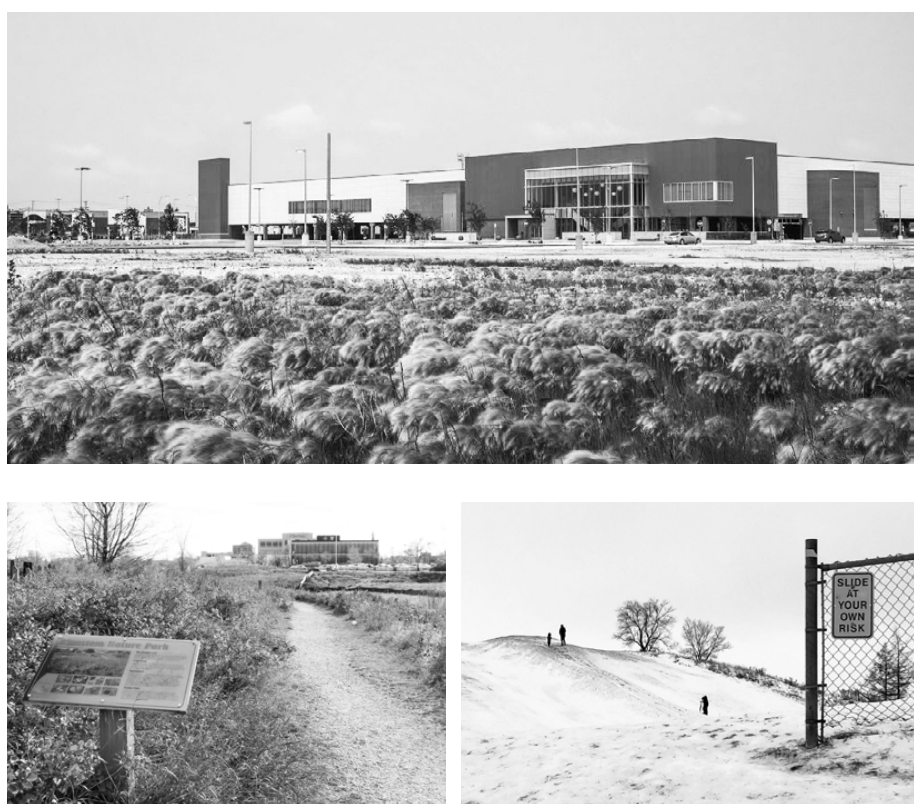

The most recent, major redevelopment on site has been the demolition of the Canad Inns Stadium in 2013 and construction of Super Target which opened and closed its doors in 2015. Although the area continues to thrive as a commercial shopping district, places of outdoor recreation still exist. Westview Park, also known as “Garbage Hill," was originally a landfill for steel and glass waste from 1875-1948. After reshaping the site for recreational use, the highest point in Winnipeg is now a popular space for dog walkers, joggers and tobogganing in the winter. Bluestem Nature Park, once a diverse and beautiful area, became a typically overdeveloped suburban tract of land. Vocal residents advocated for the land to become a park and in 1987 the native prairie restoration began. A decade later, trails were established for the landscape to be appreciated by pedestrians and cyclists. 


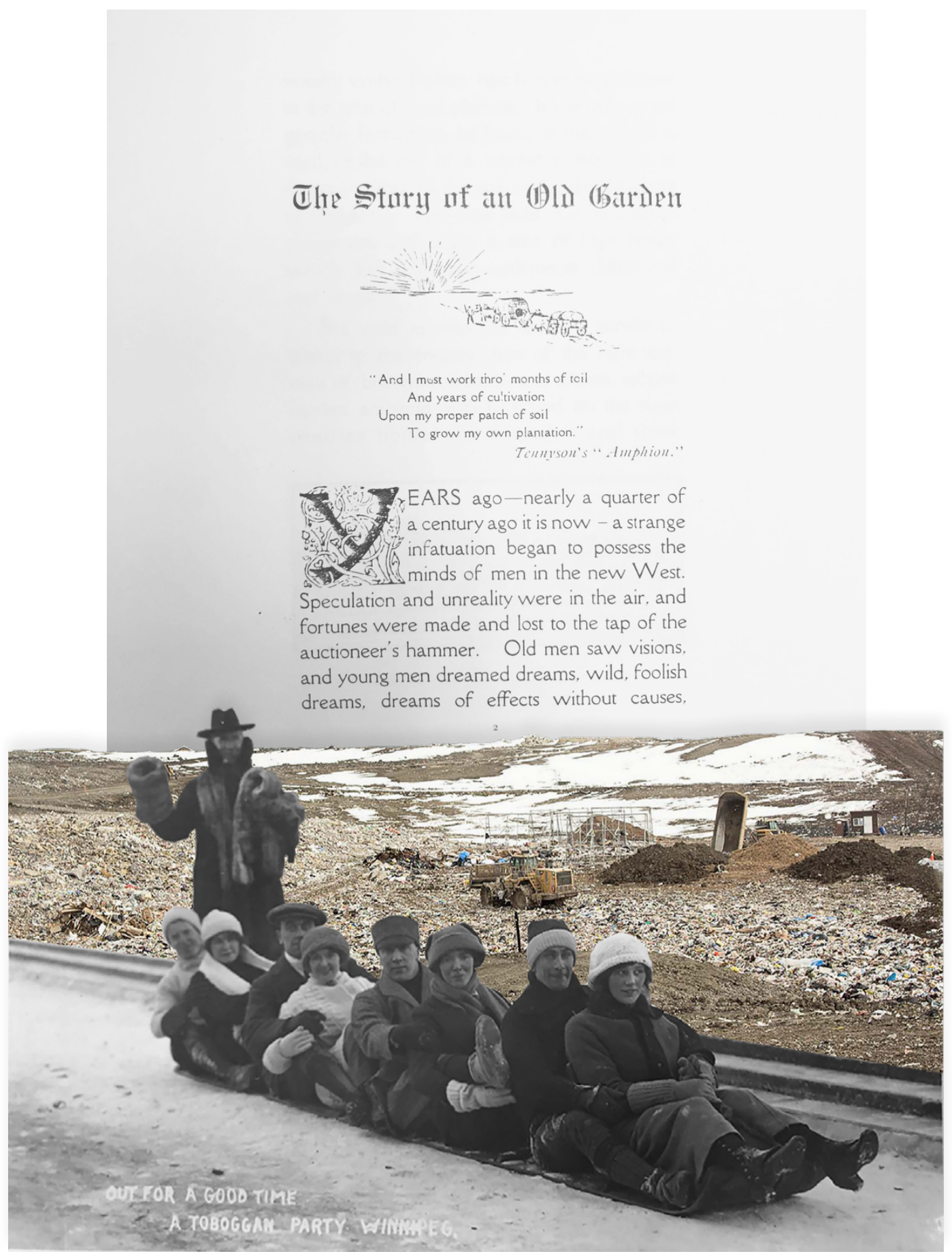

Figure 41 . The Story of an Old Garden Figure 42 . Out for a Good Time
The project attempts to tell a story of how public engagement through the landscape can strengthen our relationship with the each other and the environment. 


\section{Site History \\ 1. 1850 Land granted by the Hudson's Bay Company to build St. James Church and Cemetery \\ 2. $1875-1948$ Westview Hill Landfill \\ 3. 1910-1914 Eaton Park Place \\ 4. 1925-1956 Polo Park Racetrack \\ 5. 1953-2013 CanadInns Stadium (Football) \\ 6. 1955-2006 Winnipeg Arena (Hockey)}

7. 1959 Polo Park Shopping Centre

8. 1960 Westview Park (Garbage Hill)

9. 1960-70's Alexander Park (Soccer)

10. 1967-1991 Pan Am Games Velodrome

11. 1987 Bluestem Nature Park

12. Omand's Creek Park

13. Super Target 2015-2015

\section{Project site}

Figure 43 . Site History

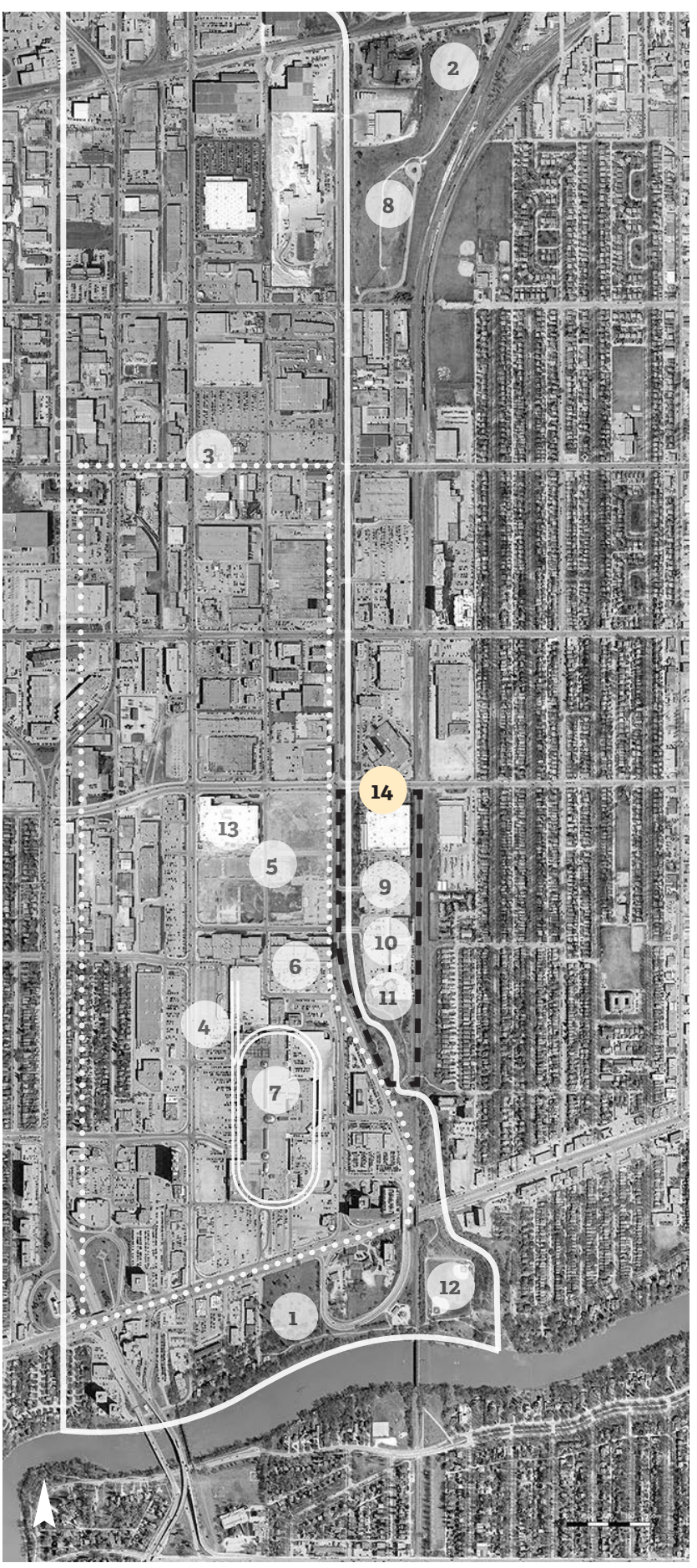




\subsection{The Site: Omand's Creek}

Figure 44. Project Site

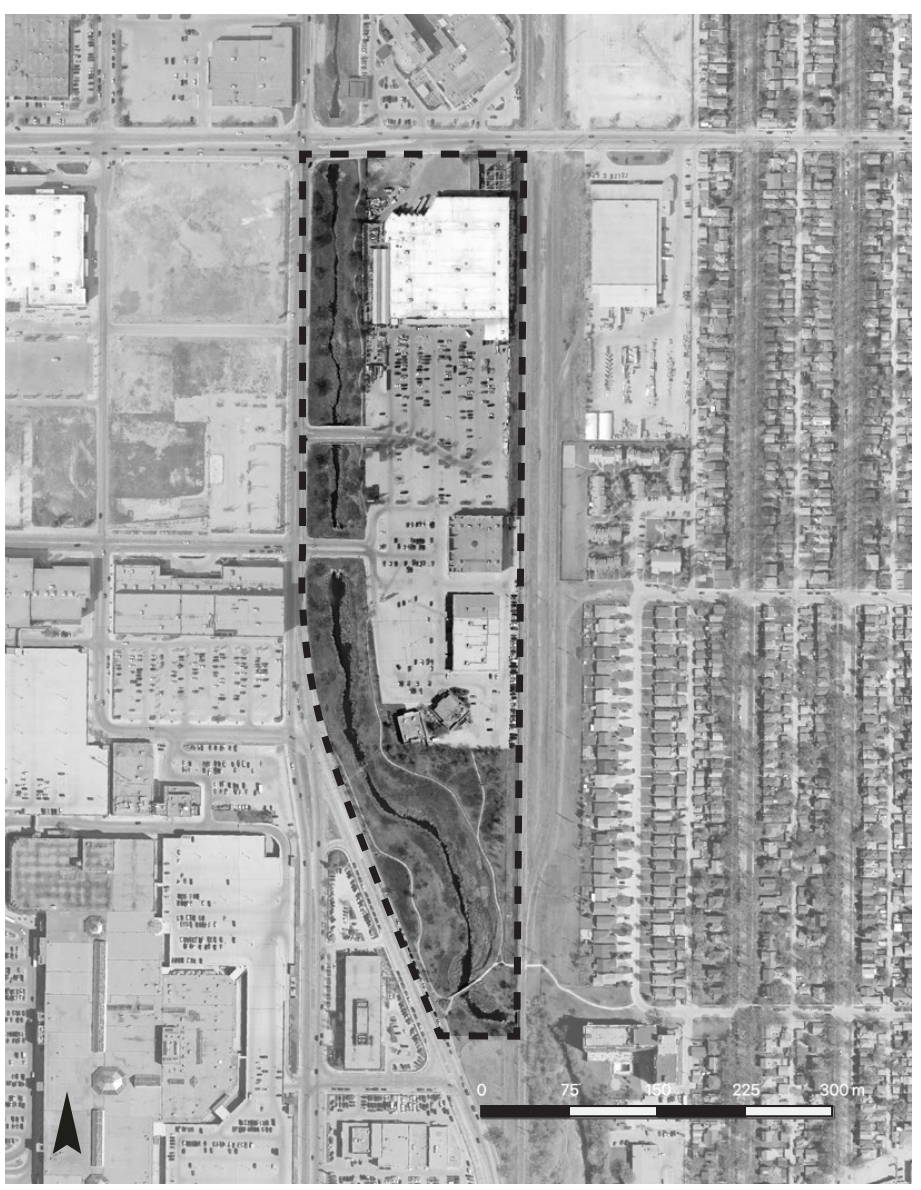

The project site is bound by Omand's Creek to the west, the Canadian Pacific Railway tracks to the east and St. Matthews Avenue to the north. The specific site straddles the natural meander of the creek and its transition into a fixed water channel. Here, there is still a connection to what the site has to offer as a natural landscape and the opportunity to create an entryway and support system for the recreational use of the land. Today the site has been leftover, completely overdeveloped and has become a forgotten natural landscape. 

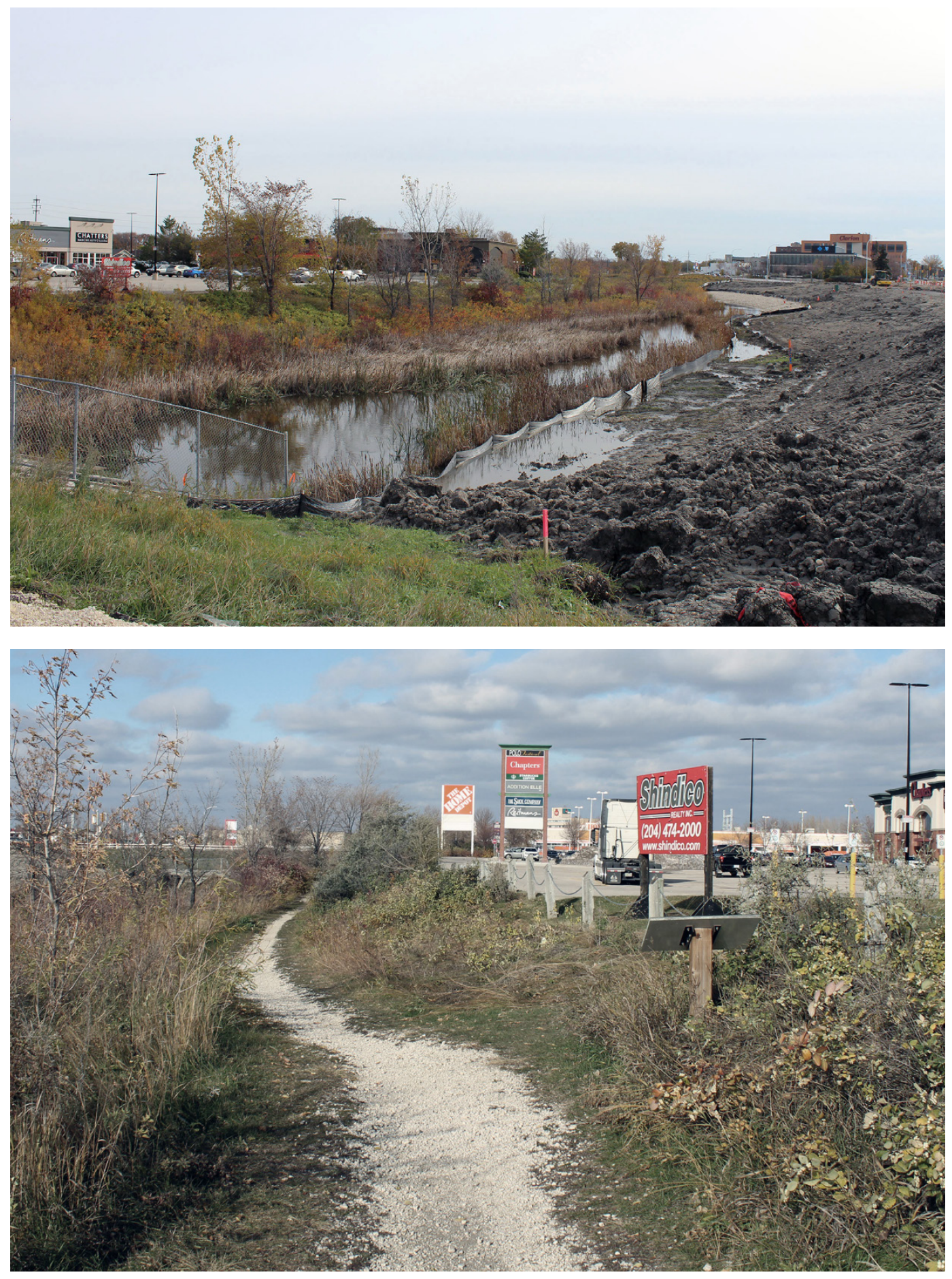

Figure 45.Site exploration: south view of the creek, October 2019

Figure 46. Site exploration: north view from walking path, October 2019 

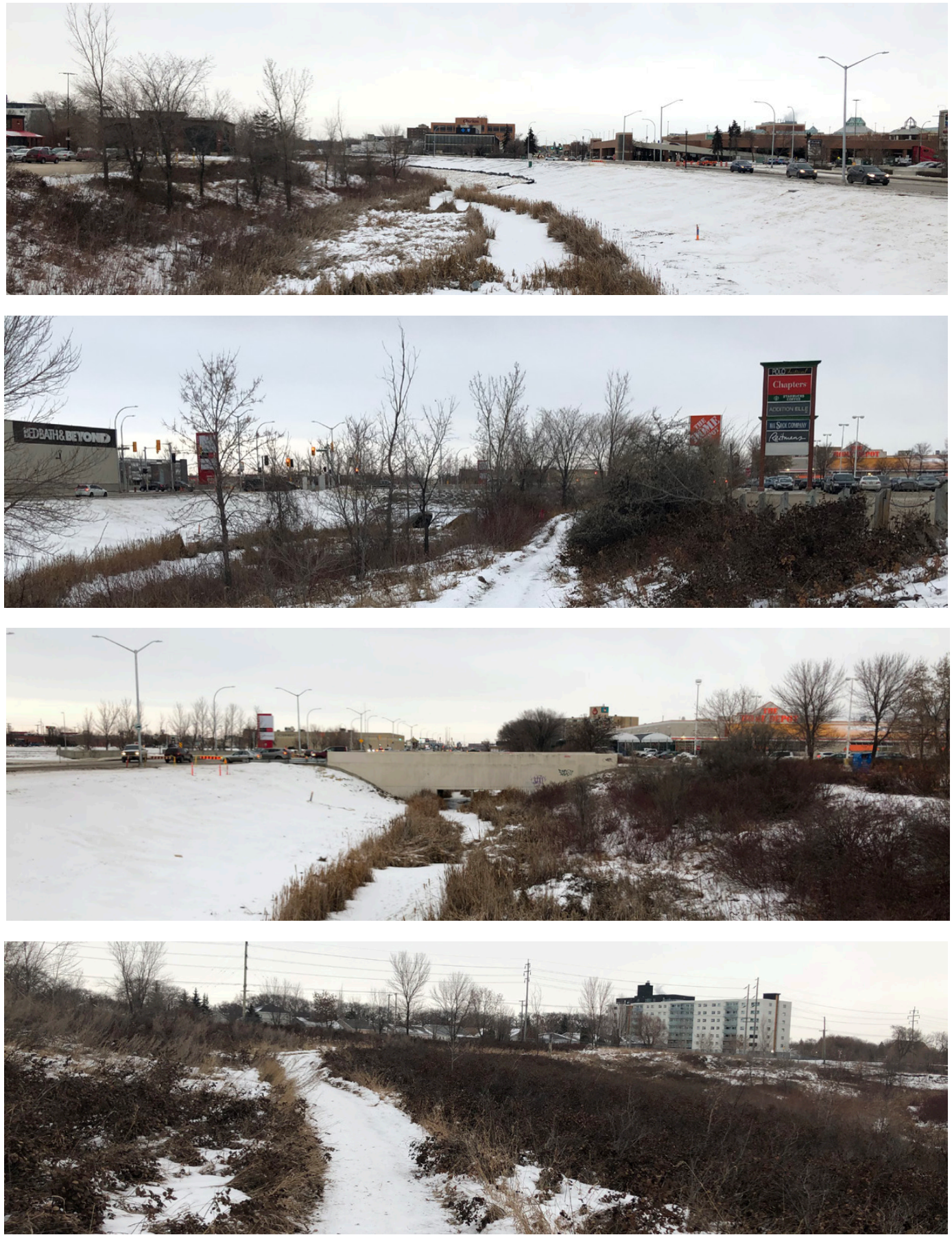

Figure 47 .Site exploration: south view of the creek, December 2019

Figure 48. Site exploration: north view from walking path, December 2019

Figure 49. Site exploration: north view from bridge, December 2019

Figure 50. Site exploration: south view toward walking path, December 2019 


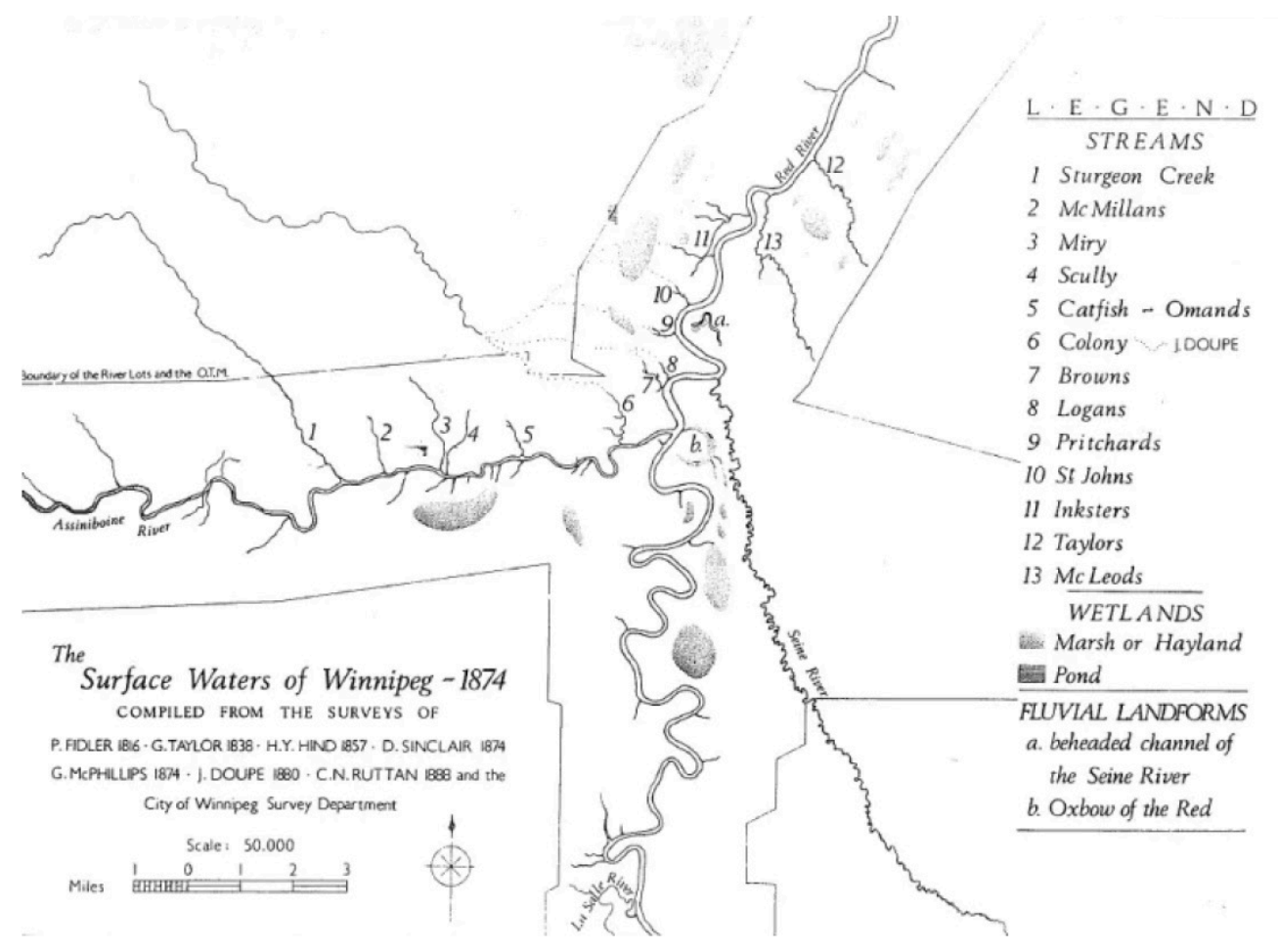

Figure 51. The Surface Waters of Winnipeg, 1874.

\section{"People think of Winnipeg as being flat, but there were creeks all over the place, all parts of the city. That was the natural landscape."}

Jim Smith, President and archivist with the North East Winnipeg Historical Society. Ghost Creeks (2018) 


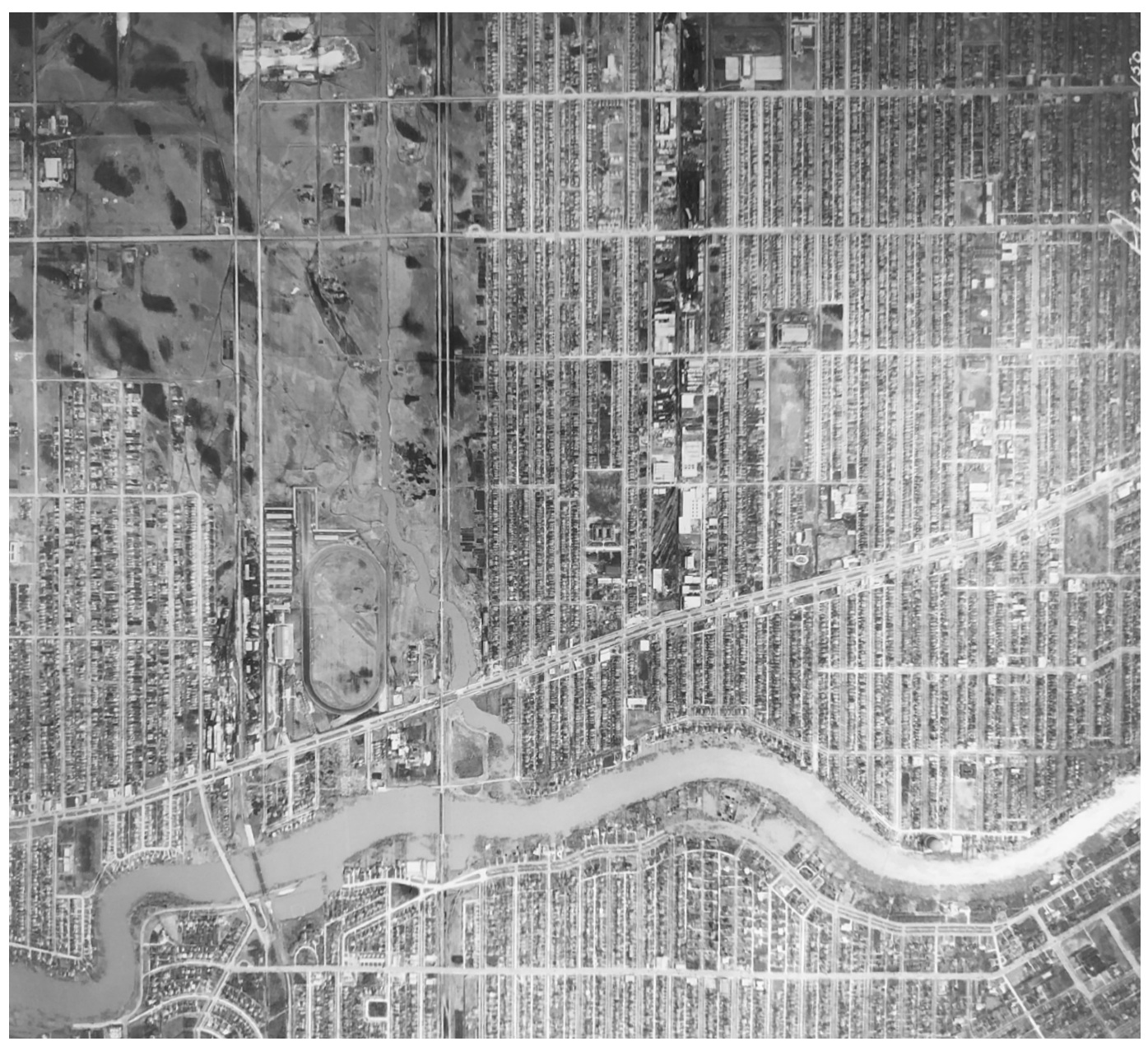

Figure 52. Aerial photograph of Polo Park Racetrack during the 1950 Flood.

Winnipeg - which means "muddy waters" in Cree - is a natural watershed. The city's location at the confluence of the Red and Assiniboine Rivers has been a meeting

57. Darren Bernhardt, "Ghost Creeks: Winnipeg Buried Many Waterways That Could Have Changed City's Shape," CBC News, September 2, 2018, https://www. cbc.ca/news/canada/manitoba/ creeks-streams-winnipeghistory-1.4641823. place for thousands of years. Within the area now bounded by the Perimeter Highway, there were once 16 major streams and 20 small creeks or coulees that carried water when fed by heavy rains or spring melt..77 With the rapid urban expansion of the city, the water table no longer has the ability to absorb and shed water, leading to flooding in the low-lying areas. 
Figure 53. Omand's Creek flooding at Portage Avenue, 1950.

58. "Historic Flood - 1950,

Government, Province of Manitoba, accessed December 20, 2019, https:// www.gov.mb.ca/mit/wms/rrf/ historical 1950.html

59. "Red River Floodway,"

Government, Province of Manitoba, accessed December 20, 2019, https:// www.gov.mb.ca/mit/wms/rrf/index. html.

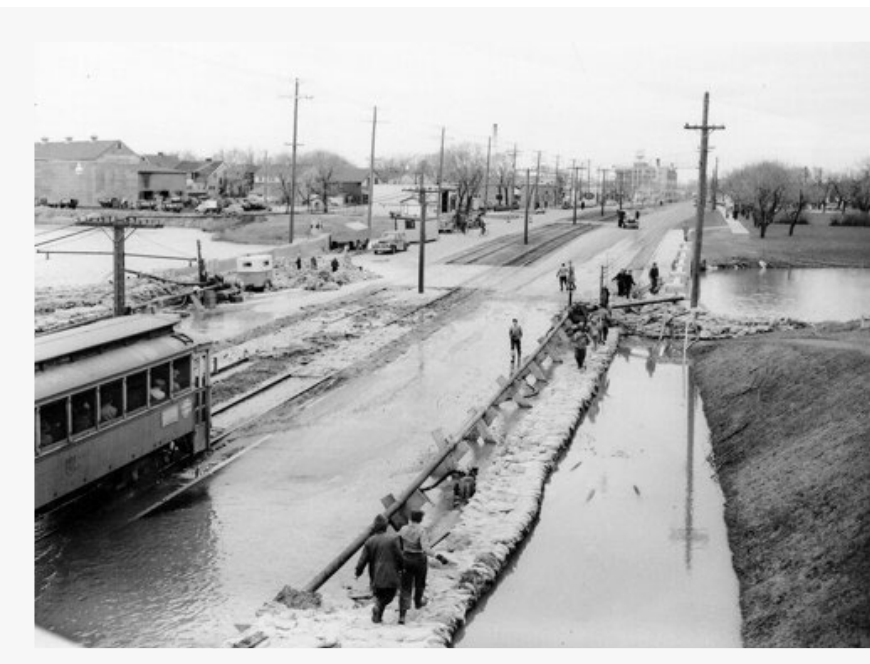

In 1950, major flooding took place and residents were evacuated from their homes - the largest evacuation in Canadian history at the time. ${ }^{8}$ To address the flooding, the Red River Floodway was built between 1962 and 1968 as flood protection measures for the City of Winnipeg. Back then, the excavation of the floodway channel was the second largest earth moving project in the world (second only to the Panama Canal).59

In an attempt to rehabilitate the area along Omand's Creek, the project imagines a municipal by-law. The expropriation of the urban stretch of land for public good is a call to action for the reunification of the site to the landscape. 


\title{
THE CITY OF WINNIPEG
}

BY-LAW NO. 22/2019

\begin{abstract}
A By-law of THE CITY OF WINNIPEG to acquire land for the purpose of construction of the Winnipeg Community Recreation Park in the City of Winnipeg, in Manitoba.
\end{abstract}

WHEREAS pursuant to The City of Winnipeg Charter in particular sections 204 and 205, the City may expropriate land and improvements considered necessary for its purposes;

NOW THEREFORE THE CITY OF WINNIPEG, in Council assembled, enacts as follows:

The City hereby expropriates the following land:

The land contained within Lot 42 in the Parish of St James along Omand's Creek from a point 300 feet north of Portage Avenue to St Matthews Avenue

for the purpose of construction of the Winnipeg Community Recreation Park, in the City of Winnipeg, Manitoba

2 The proposed work is hereby deemed to be necessary for the purpose of environmental rehabilitation and physical recreation in the said assessment area.

3 The lands to be benefited by the proposed work are all the lands contained within the said assessment area.

4 The cost of the care and maintenance of said land shall be paid out of the annual levy for park, recreation and environmental purposes. 


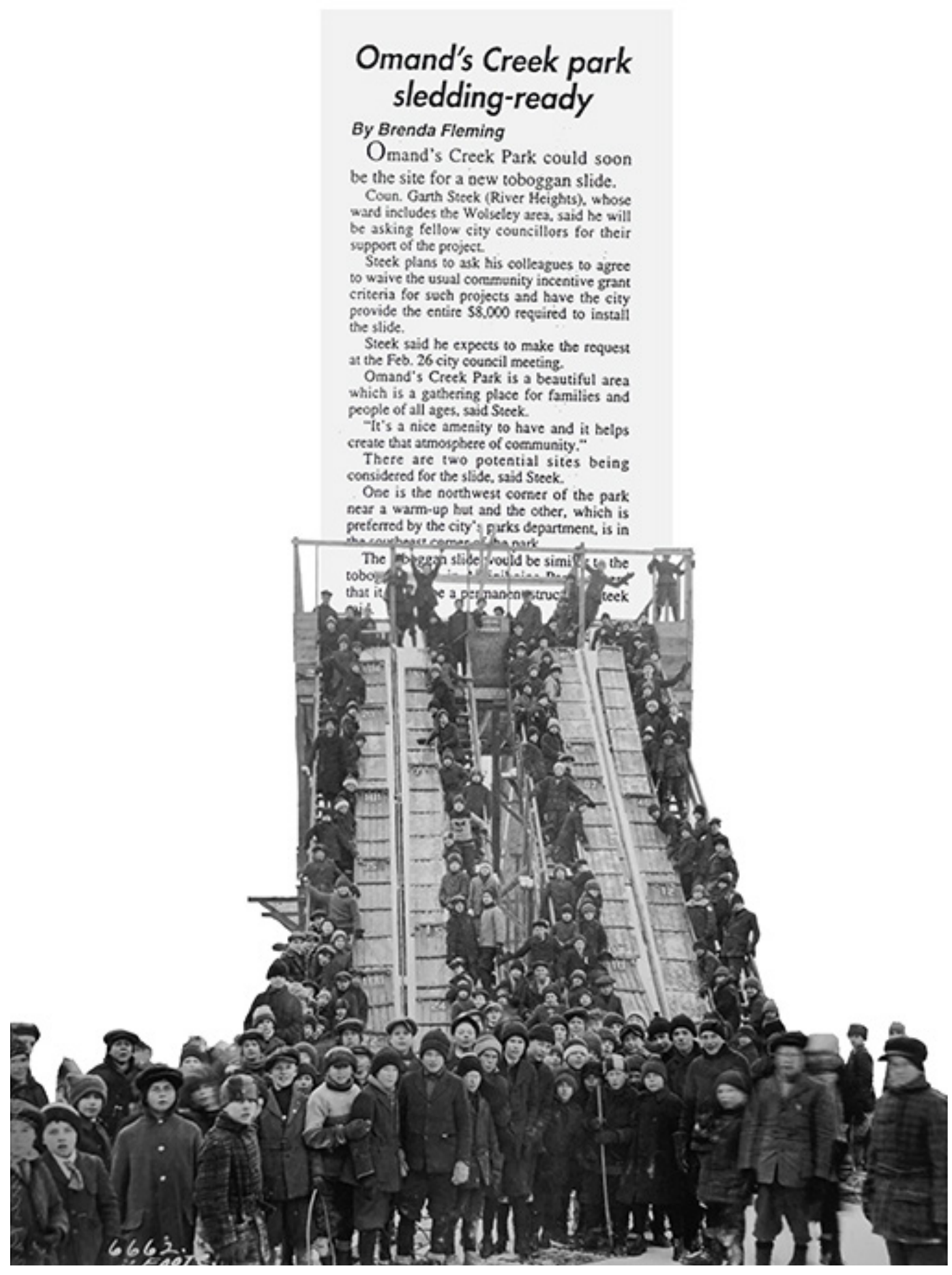

Figure 55. Omand's Creek park sledding-ready.

Figure 56 . Free Press carriers toboggan party at River Park.
The work explores recreational infrastructure to support outdoor activity and restores elements of Winnipeg's vernacular as a starting point to the project's design. 
Chapter 3: Initial Studies 
Initial Studies

The research began with an investigation of physical activity and leisure associated with sport throughout history. Origins of sport, as we know today, had various cultural significances to specific periods and places around the world. A card game created an opportunity to display the research through a timeline and game board. The content, although varied through time and place, is seamlessly connected through the game. From the research, explorative drawings layered seemingly unrelated sports equipment that revealed their connection to the landscape. Form finding studies pulled ideas from the drawings which developed throughout the project. 
3.1 Cards of Recreation Throughout the game, the cards create a timeline of sport throughout history. The game not only educates the players, but also engages them in the leisure activity and social interaction explored in the project.

Figure 57. Playing Cards

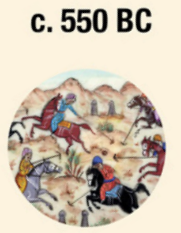

Polo originates in the Persian empire, probably as part of the training of the imperial calvry.

Figure 58. Game Play
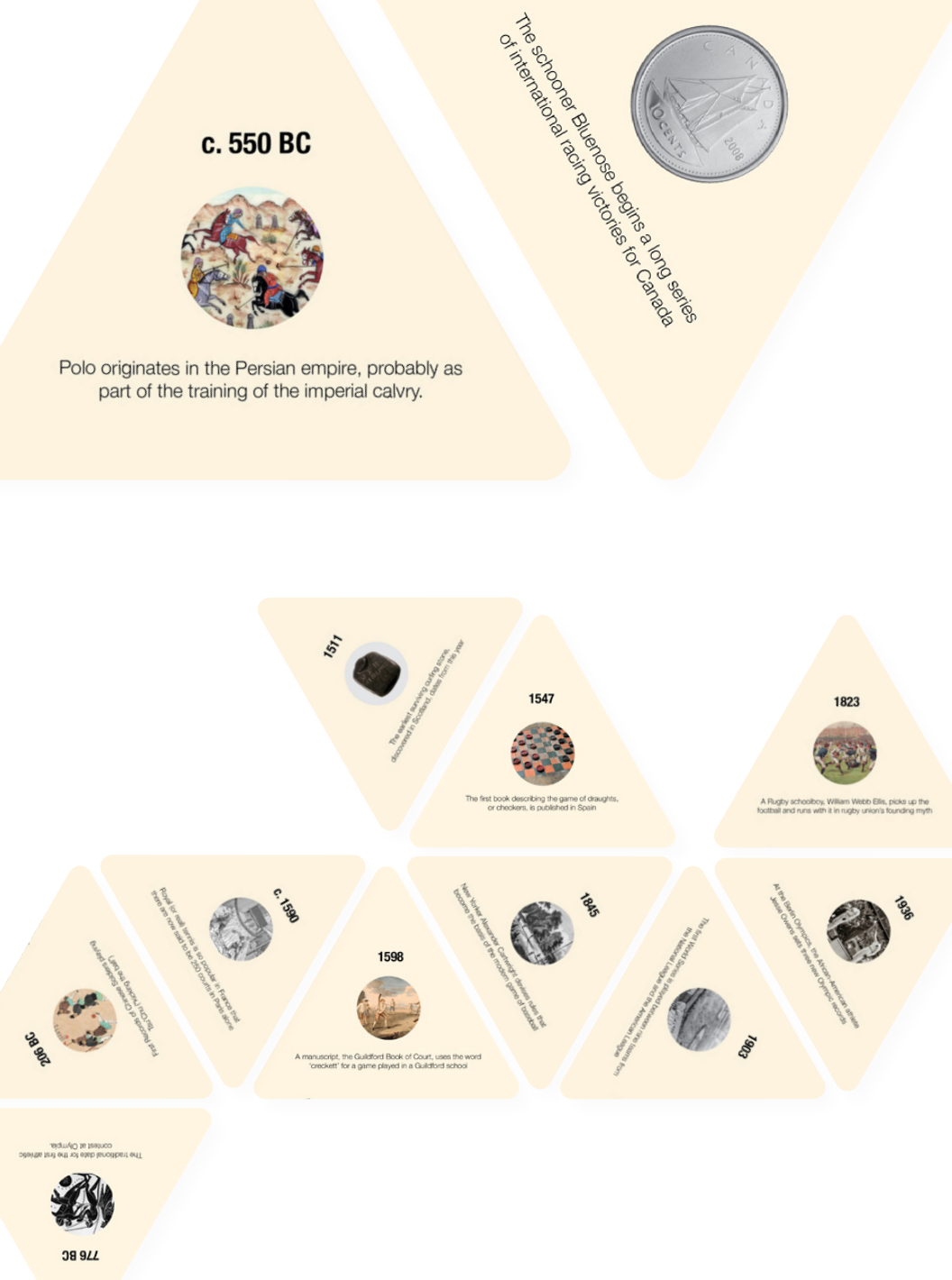

Figure 58. Game Play 


\subsection{Composite Drawings}

Composite drawings were created as a way to initiate

form finding from the research of physical activity

throughout history. The drawings became an exercise,

inspired by Douglas Darden, in understanding the

relationship between the object, the body, and the

land. The compositions were created with equipment

associated with sport today and organized by its use.

Each apparatus was originally designed or used for

a specific function to augment, hold, strengthen or

entertain the body. 
Survival - Augment the body to aid in gaining nourishment.
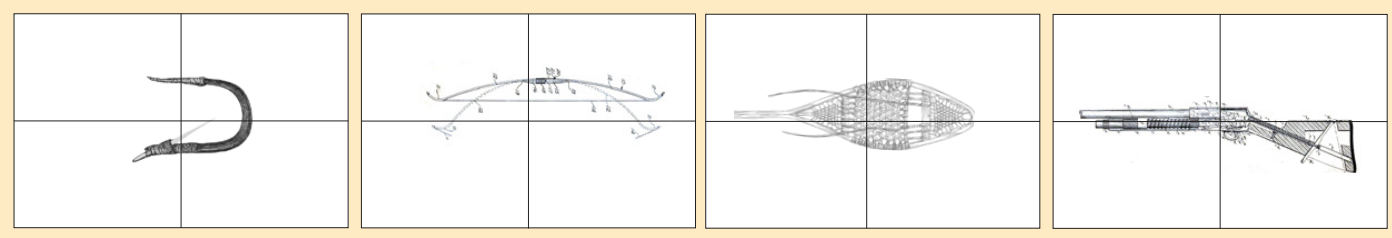

1. Steam-bent fish hook

2. Archery Bow

3. Dene Snowshoe

4. Hunting Rifle

5. Image Composite
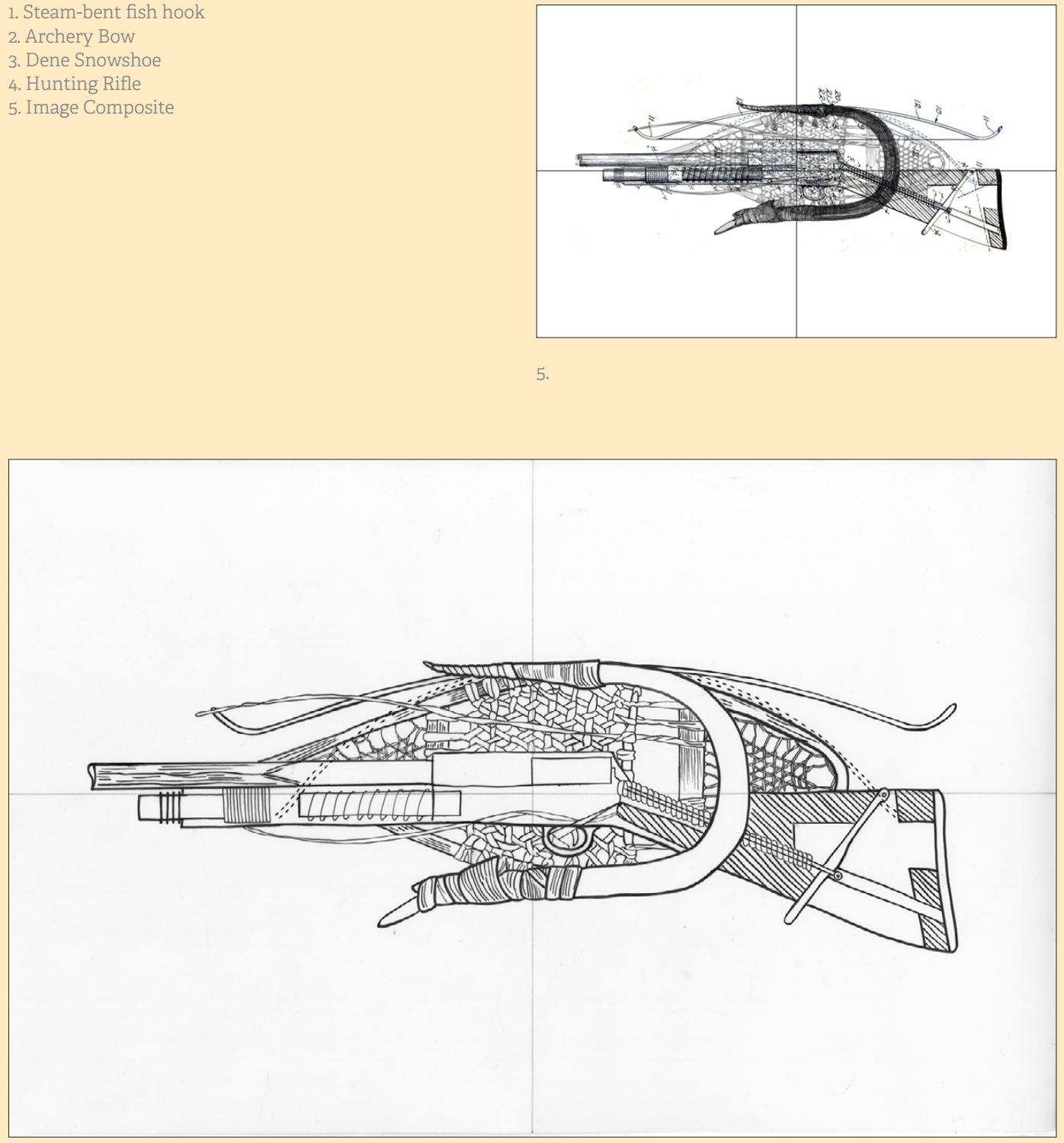

Figure 59. Composite Drawing I 
Transport - Hold the body to traverse and explore
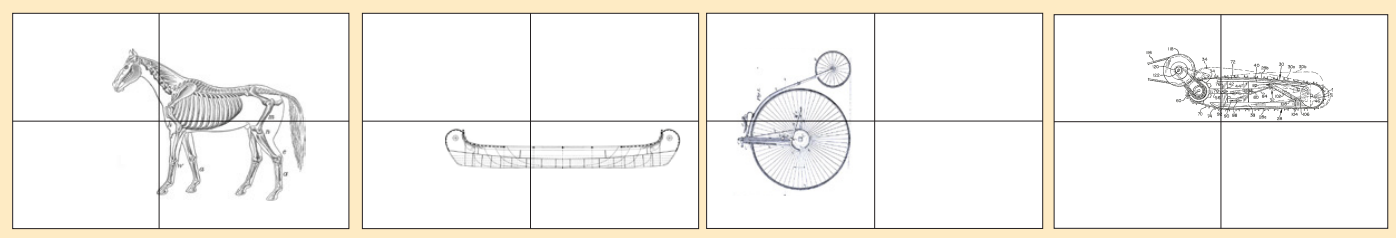

2.

3.

4.

1. Horse

2. Voyaging Canoe

3. High Wheeler Bicycle

4. Snowmobile gears and tracks

5. Image Composite
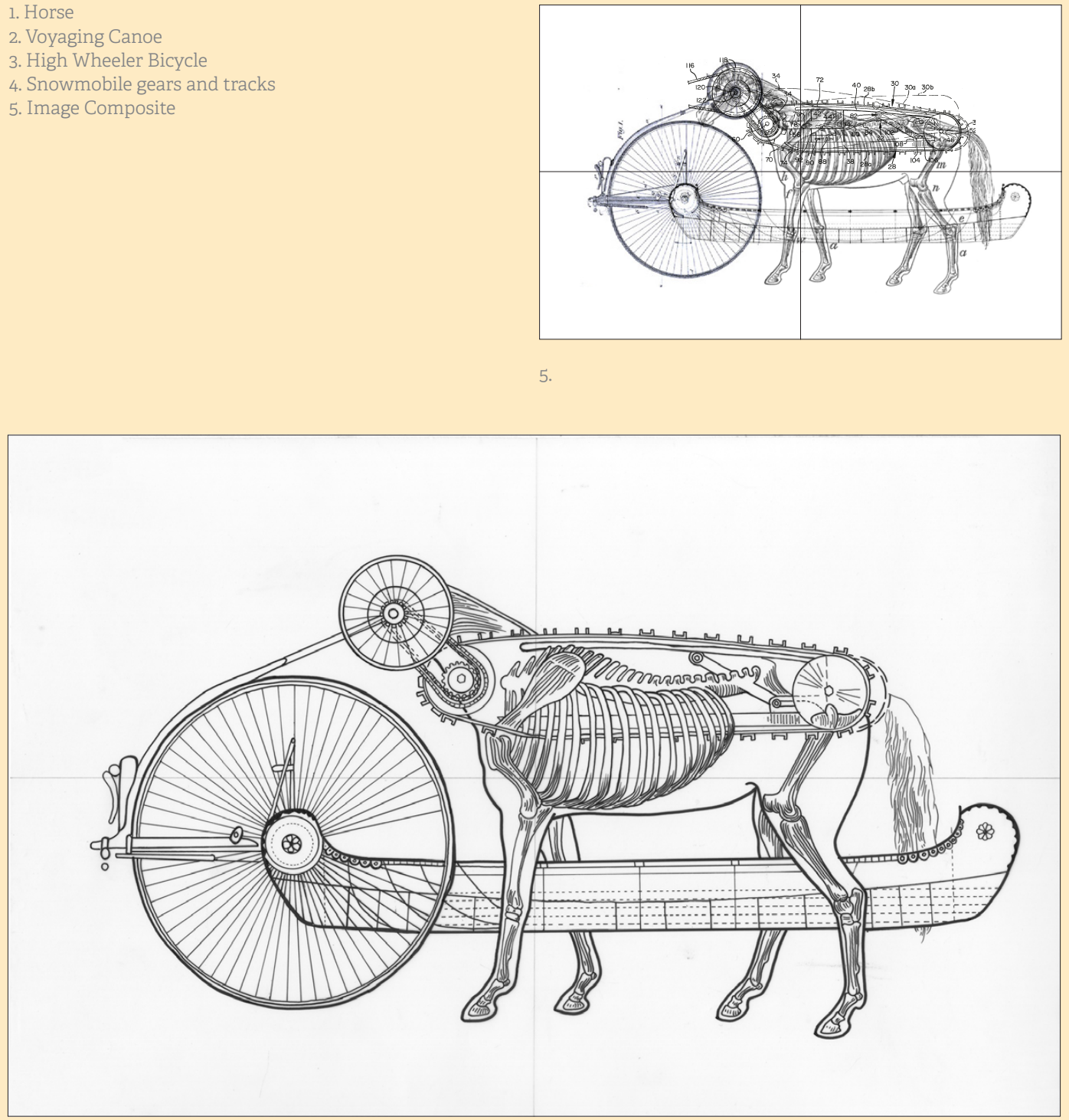

Figure 60 . Composite Drawing II 
Training - Strengthen the body to increase skill.

1. Lacrosse Scoop

2. Polo mallet

3. Rowing machine

4. Monkey Bars

5. Image Composite

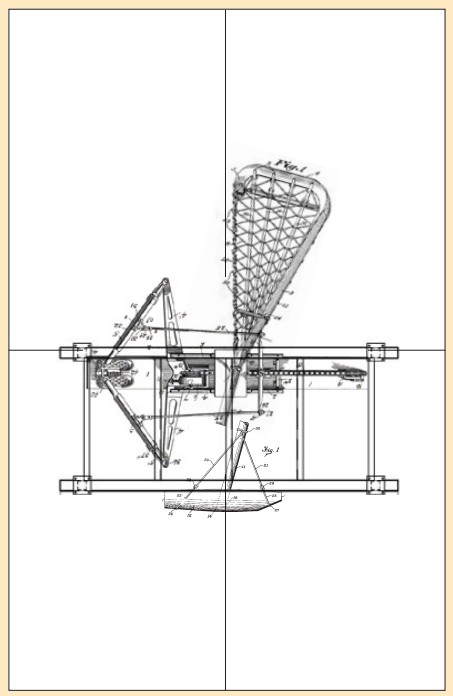

5.

Figure 61 . Composite Drawing III
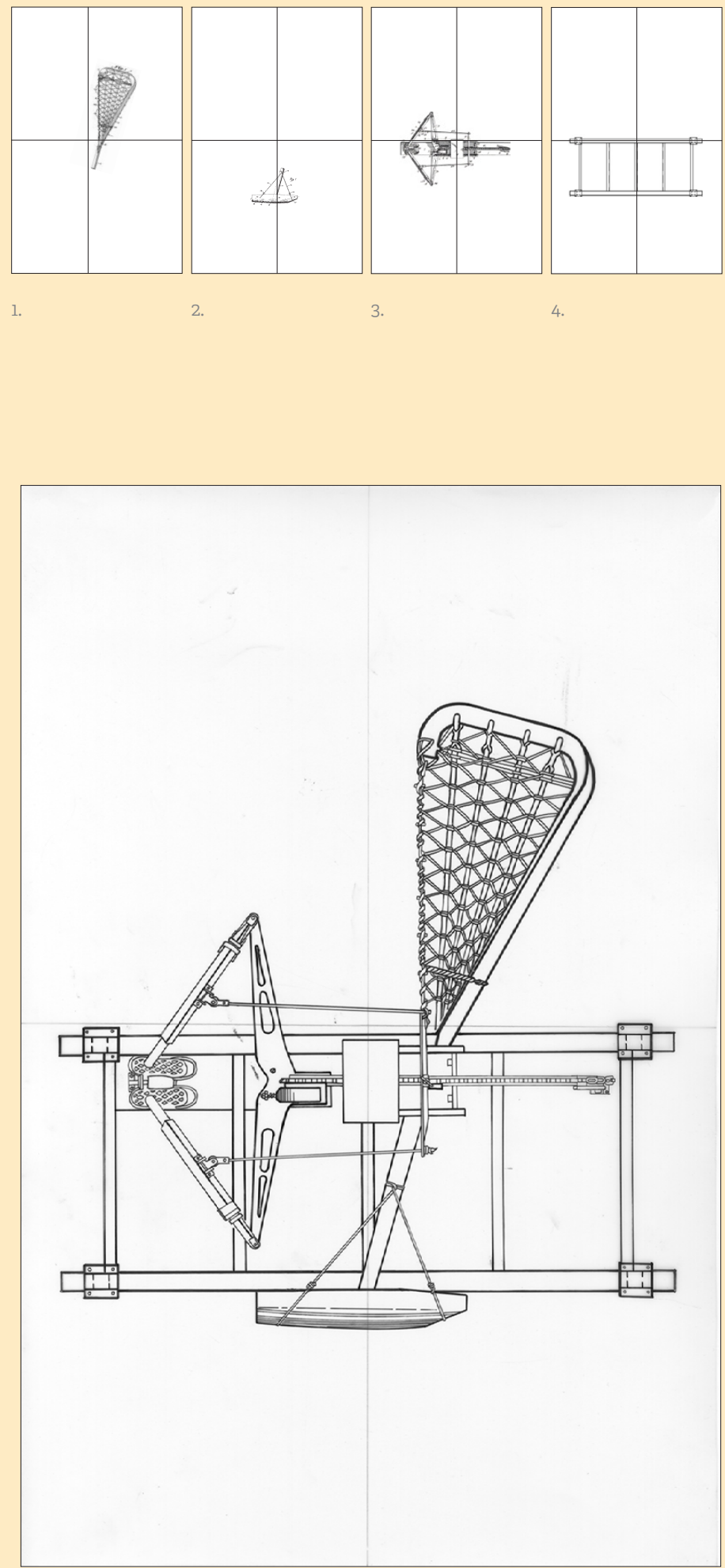
Leisure - Entertain for refreshed body, mind and spirit.

1. Slide

2. Bobsled

3. Toboggan Slide (section)

4. Toboggan Slide (plan)

5. Image Composite

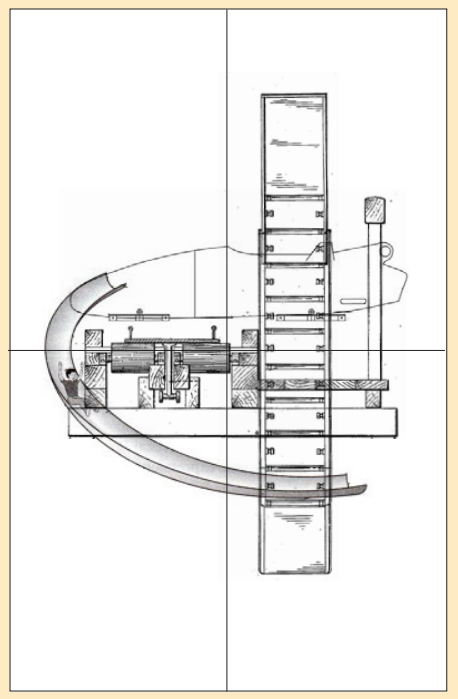

5.

Figure 62 . Composite Drawing IV
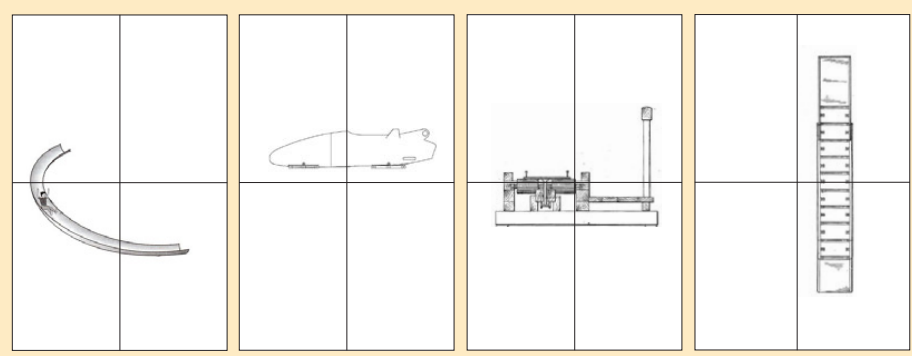

2.

3.

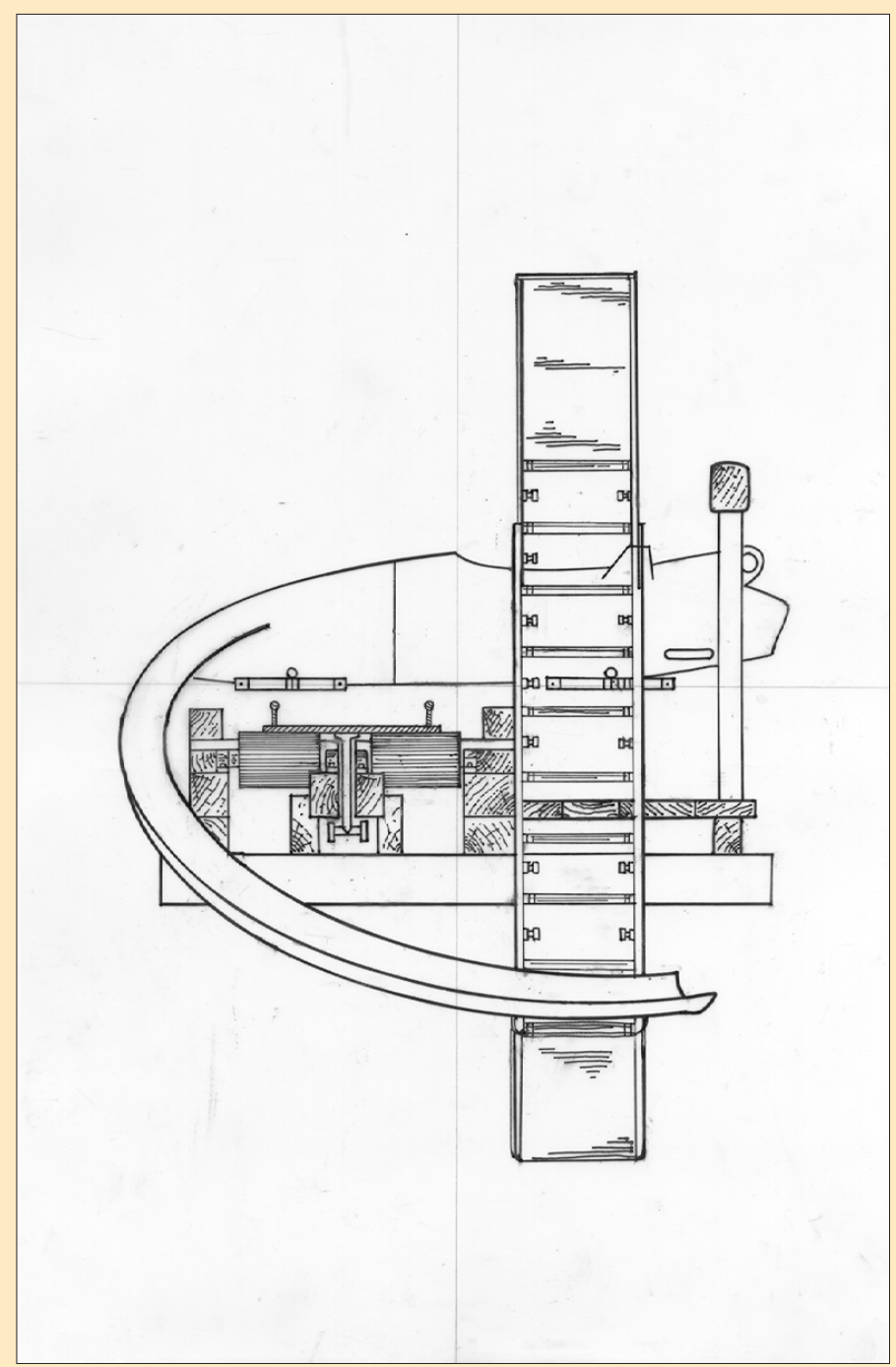


From the compositions, the relationship between the body and the landscape became apparent. Physical activities and objects built out of necessity were once tied to the material and the land. The realtionship between body and equipment is now ubiquitous and disconnected from the environment.

How can space for physical activity rehabilitate this relationship with the landscape and perhaps aid in shaping a civic consciousness for a better tomorrow? 
3.2 Site and Building Studies

Figure 63. Site Study I - plan

Figure 64. Site Study I - roof
Initial attempts at a building design pulled ideas and forms from the composite drawings. The curve and torque of materials to serve a new function inspired the structure and shape of the studies. To create these shapes, armatures are built to hold materials in place. Using sport as the navigator between activity in the land and the activity of gathering, the building attempts to act as the armature, holding back the earth, while opening up into the landscape. Spaces become a vessel for activity, weaving together the built and the natural.
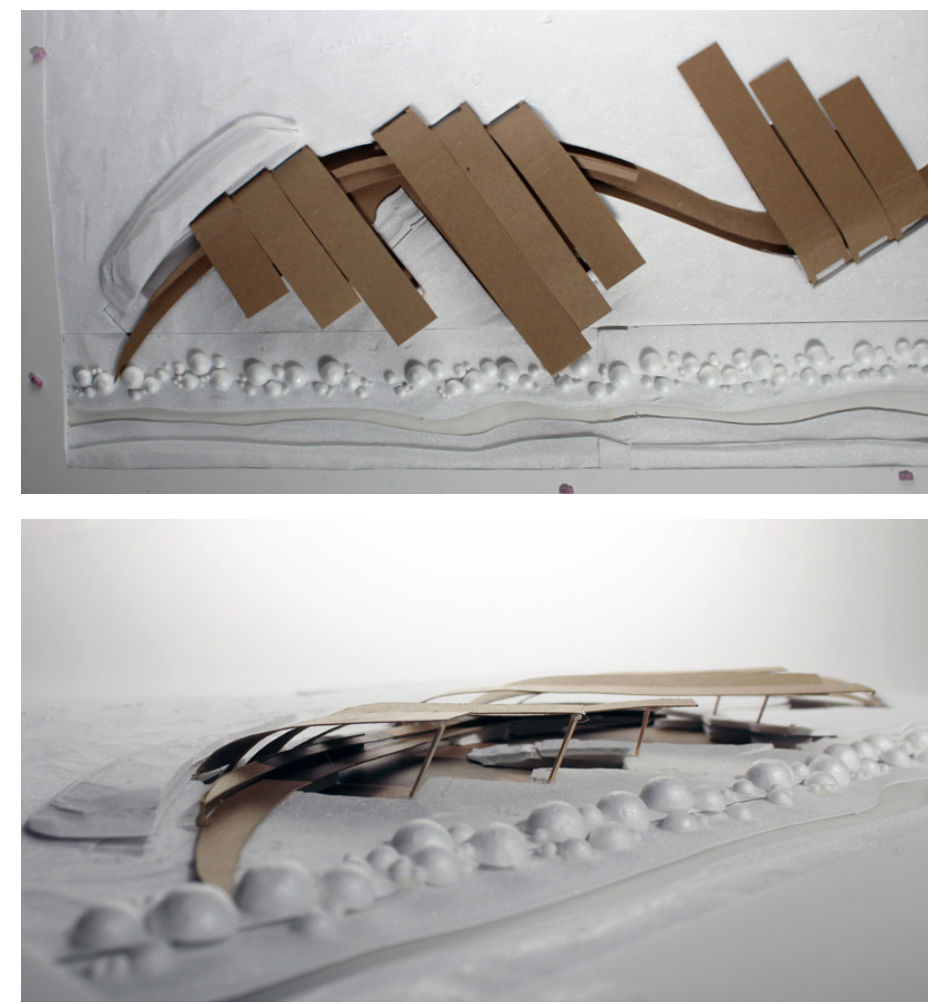

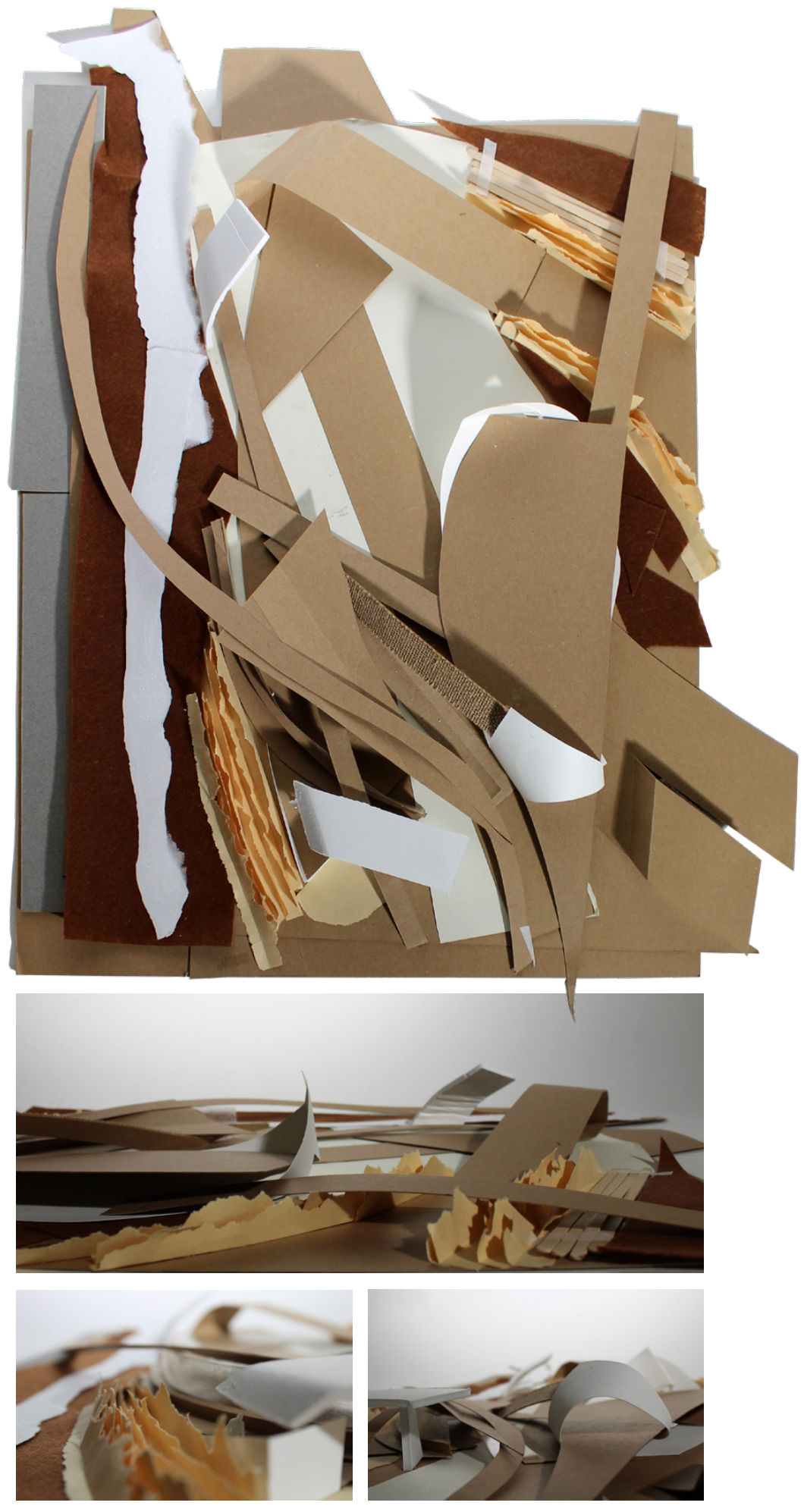

The previous model's rigidity in contrast to its scrap material inspired the study model above. Here, the notions of tension, weaving, bending, curving and torque become apparent. The organic forms create more intimate and curious spaces for the body to explore. 

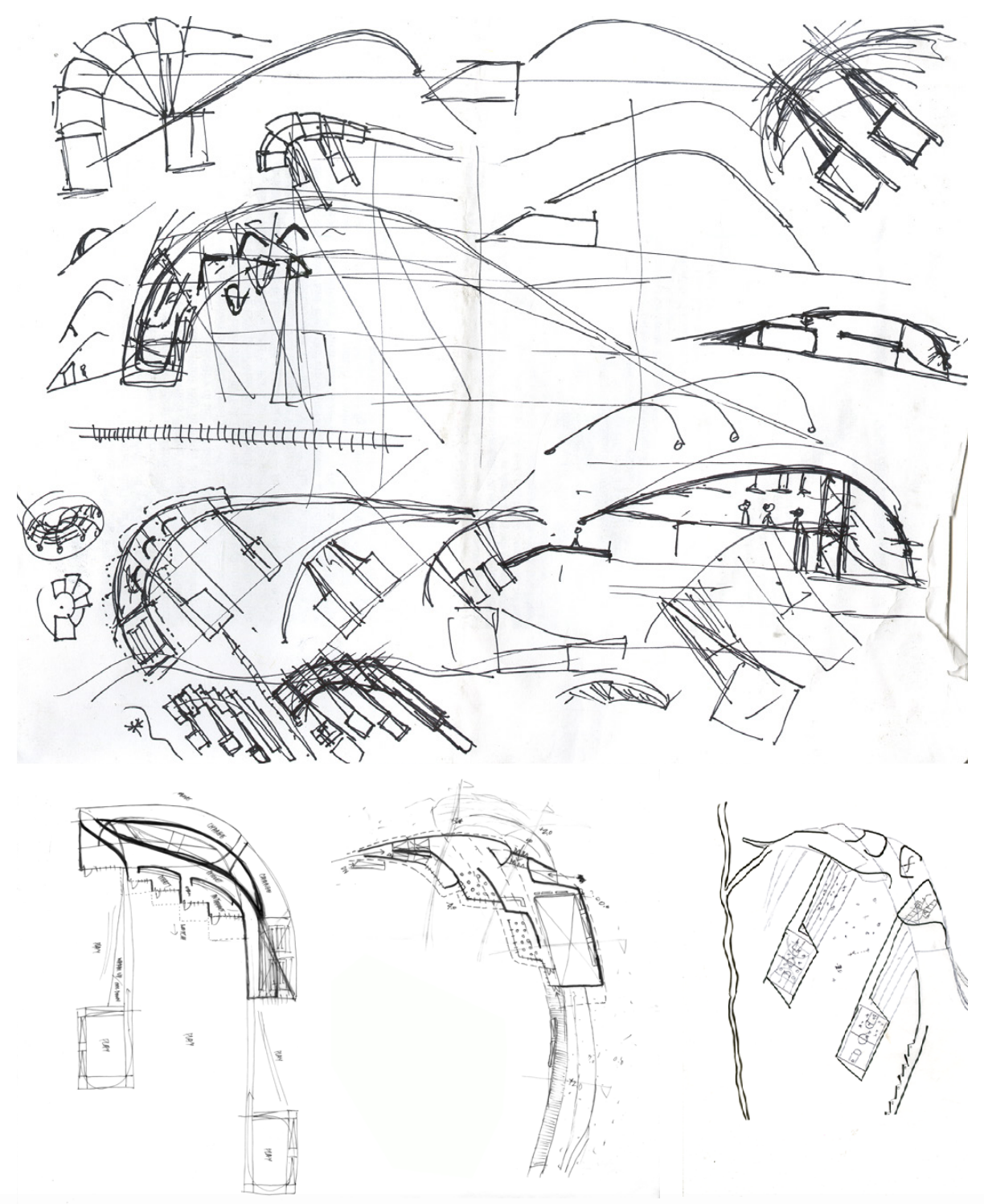

Figure 67. Sketch Studies

Figure 68 . Building Design Fall Term

With sport being dictated by the rules and boundaries

of the field and court, the design focuses on the activity before, during and after sporting activies. Moments where athletes and spectators diverge, gather, wait, interact, celebrate and journey to and from the fields and courts. 

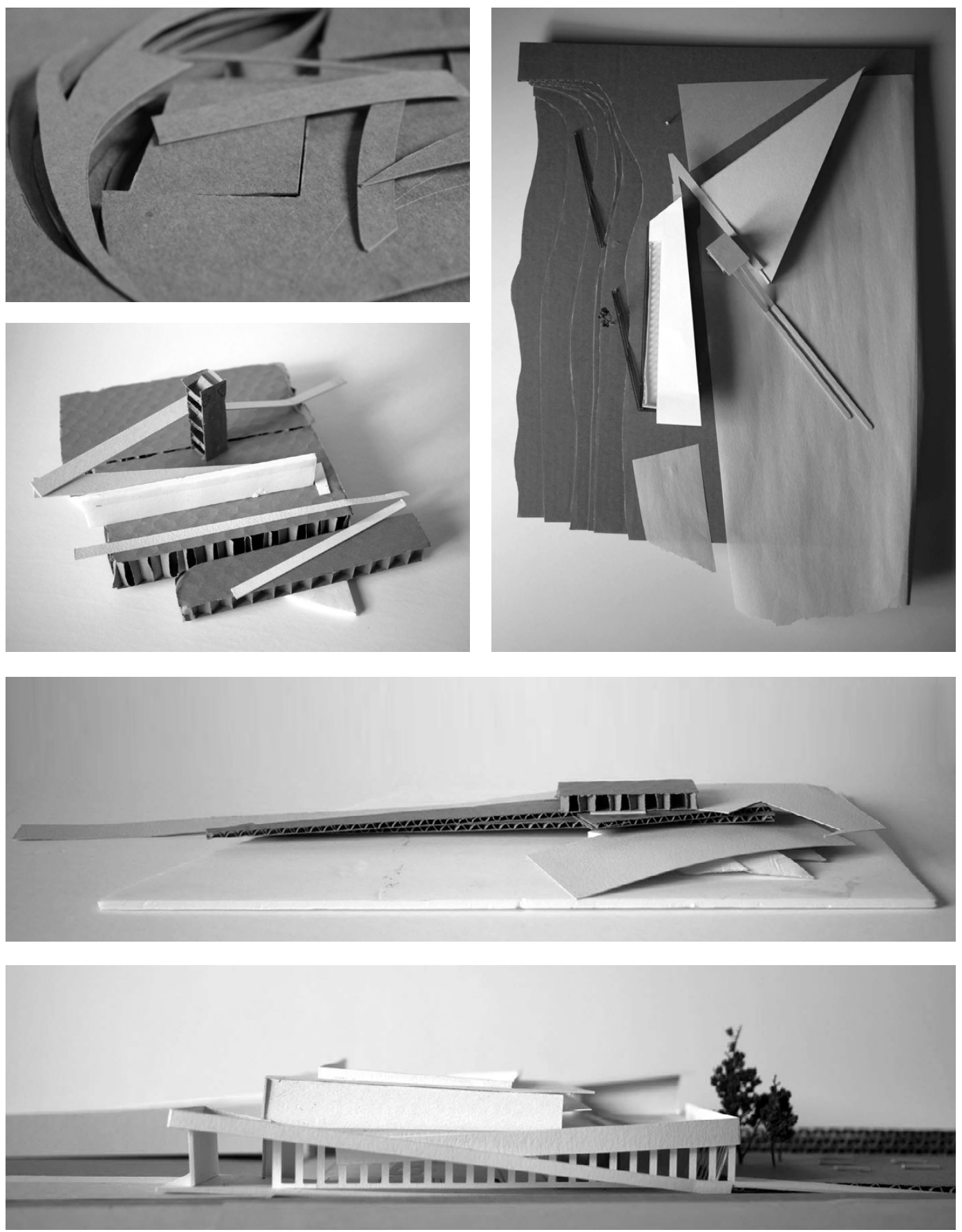

Figure 69. Outpost studies 
Chapter 4: Off the Field 


\subsection{Site Proposal}

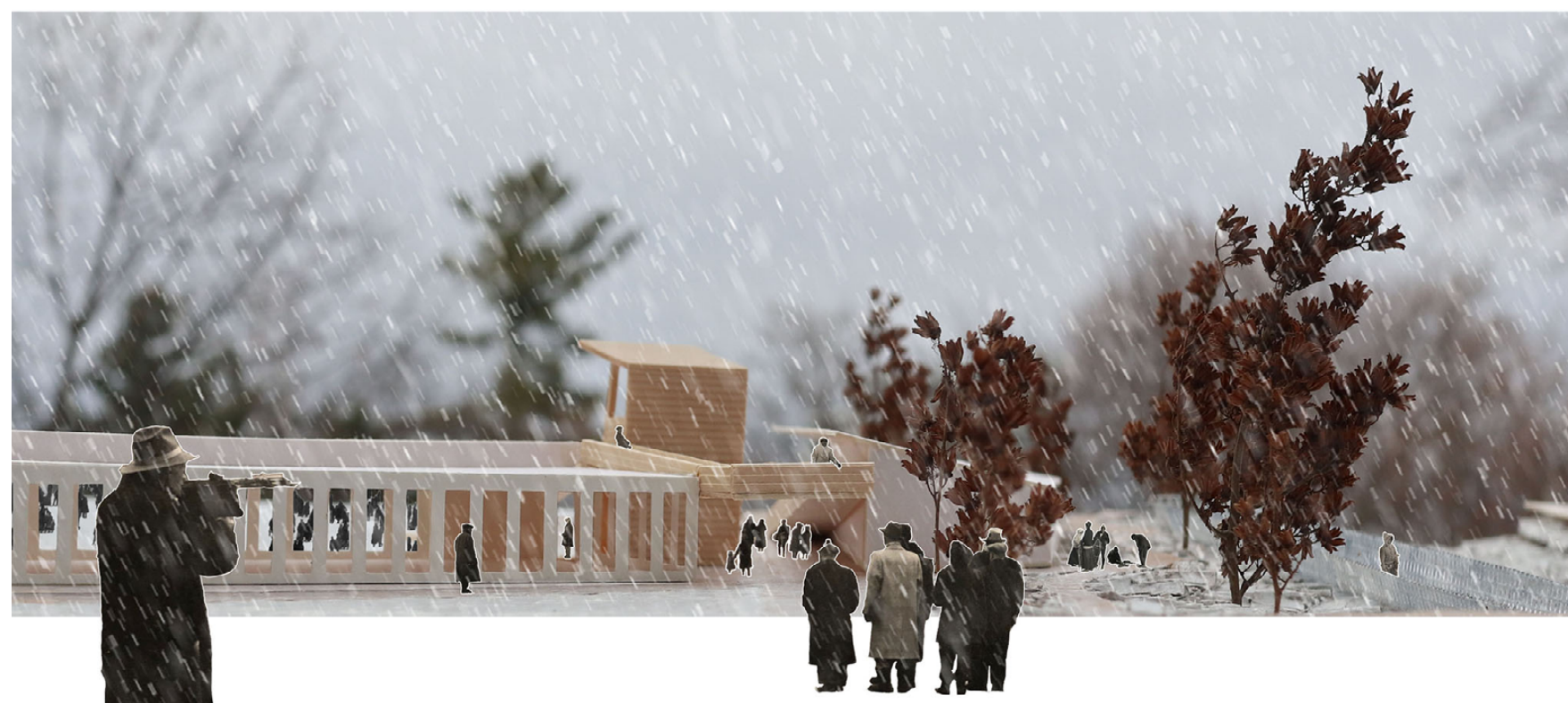

Figure 70. Seasonal Port Entrance Perspective

Today, the word "recreation" and "re-creation" have seemingly different meanings, but both originally referred to as "a process of creating anew." This could be extended to cover any sustaining act to restore to a good or normal physical condition from a state of weakness or exhaustion. Having a meal, being physically active or enjoying a social gathering, by virtue of their nourishing properties, were thought to create the body, mind and spirit anew. The design of the proposal, therefore, attempts to recreate the social and natural infrastructure once present on the site, and reconnect the relationship between the body, community and the landscape. 


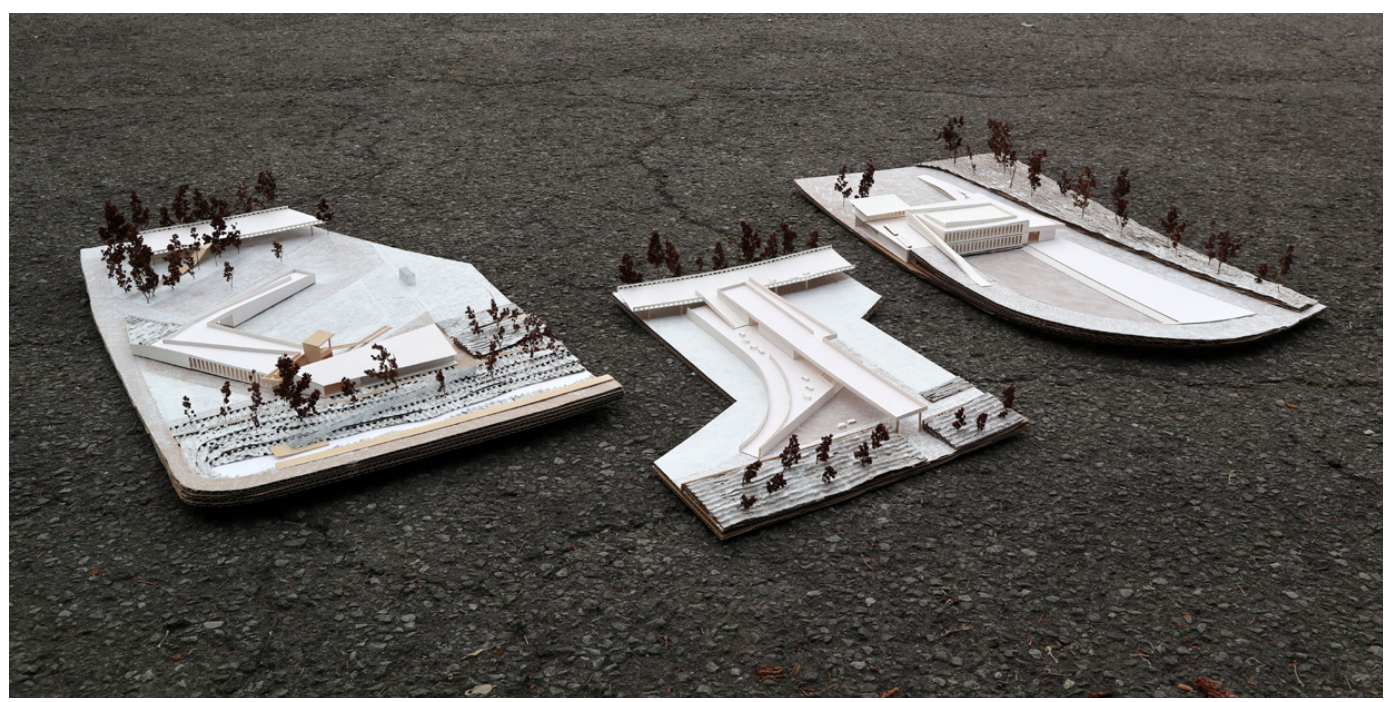

To develop and maintain a healthy, diverse and

60. Irene Cheng, ed., "Active Design Guidelines: Promoting Physical Activity and Health in Design" (Center for Active Design, 2010), https:// centerforactivedesign.org/dl/ guidelines.pdf, 22

61. Ibid, 23.

62. Ibid. accessible streetscape, researchers have identified five

“ $\mathrm{D}$ " variables key to analyzing the relationship between

urban design and travel patterns: density, diversity, design, destination accessibility and distance to transit. ${ }^{60}$ The Polo Park area meets all of these relationships except design, which is the least well-studied of the five variables in part because it is the most nuanced and hard to measure. ${ }^{61}$ A recent study funded by the Robert Wood Johnson Foundation's Active Living Research Program developed five qualitative design qualities to be critical to a good walking environment and related to physical features of the street environment: imageability, enclosure, human scale, transparency and complexity. ${ }^{62}$ The proposal for the project uses these design directives to realize these qualities conducive to physical activity. 
Site Plan

1. Toboggan Run

2. Seasonal Port

3. The Restaurant \& Cafe

4. Natural Playground

5. Storage Slope

6. The Platform

7. Playing Field

8. Market Space

9. Resting Place

10. Picnic Pavilion

11. Exchange Rooms

11. Bowling / Curling

12. Boardwalk

13. Plaza

14. Exhibition Space

15. The Gymnasium

16. Exercise Pavilion

1:2500

Figure 72 . Site Plan Proposal

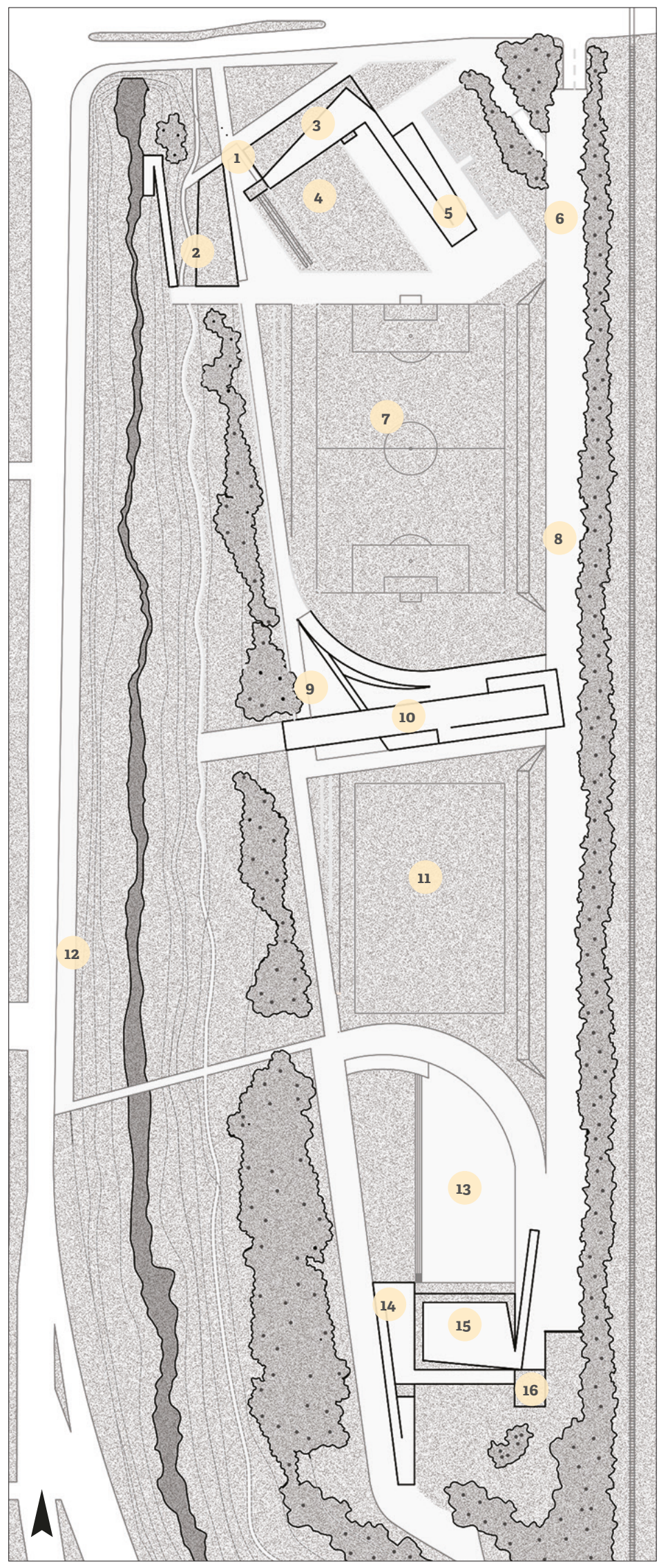




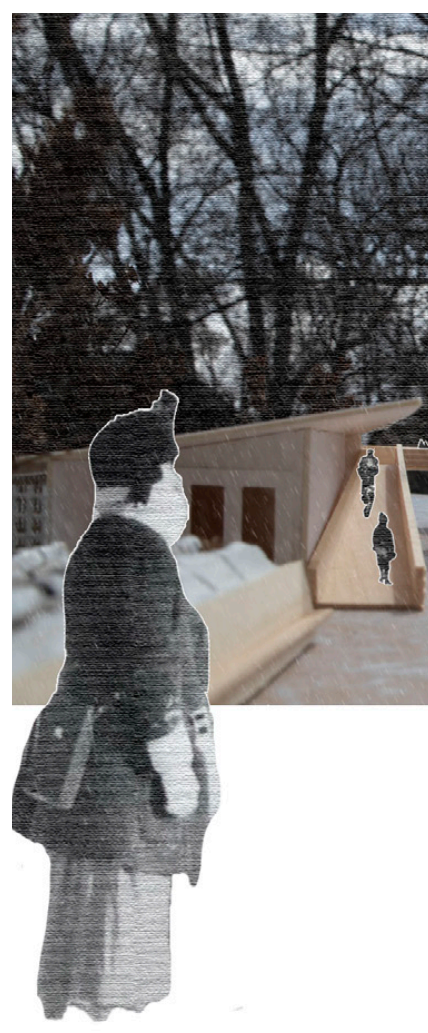

Figure 73. Winter Perspective Seasonal Port and Toboggan Slide

Manipulating the land became a gesture to the once desirable landscape. The ramped areas create multiple opportunities for activity and smaller pathways meander through the landscape allowing users to traverse the entire site. Berms on either side of the main path are built up for the pathway to cut through, while the height of the berms block views toward the urban area and allow for moments of rest and play.

The main buildings are separated to engage the site in between, while multiple points of entry allow access to the site from various modes of transportation. The buildings are integrated into the landscape elements to suggest their permanence and rootedness. Framed views borrow from the landscape beyond and encourage visitors to explore the site. These gestures are used to create spaces of social collaboration not only for sport, but theatre, market and exhibition areas to engage the site during different seasons. 

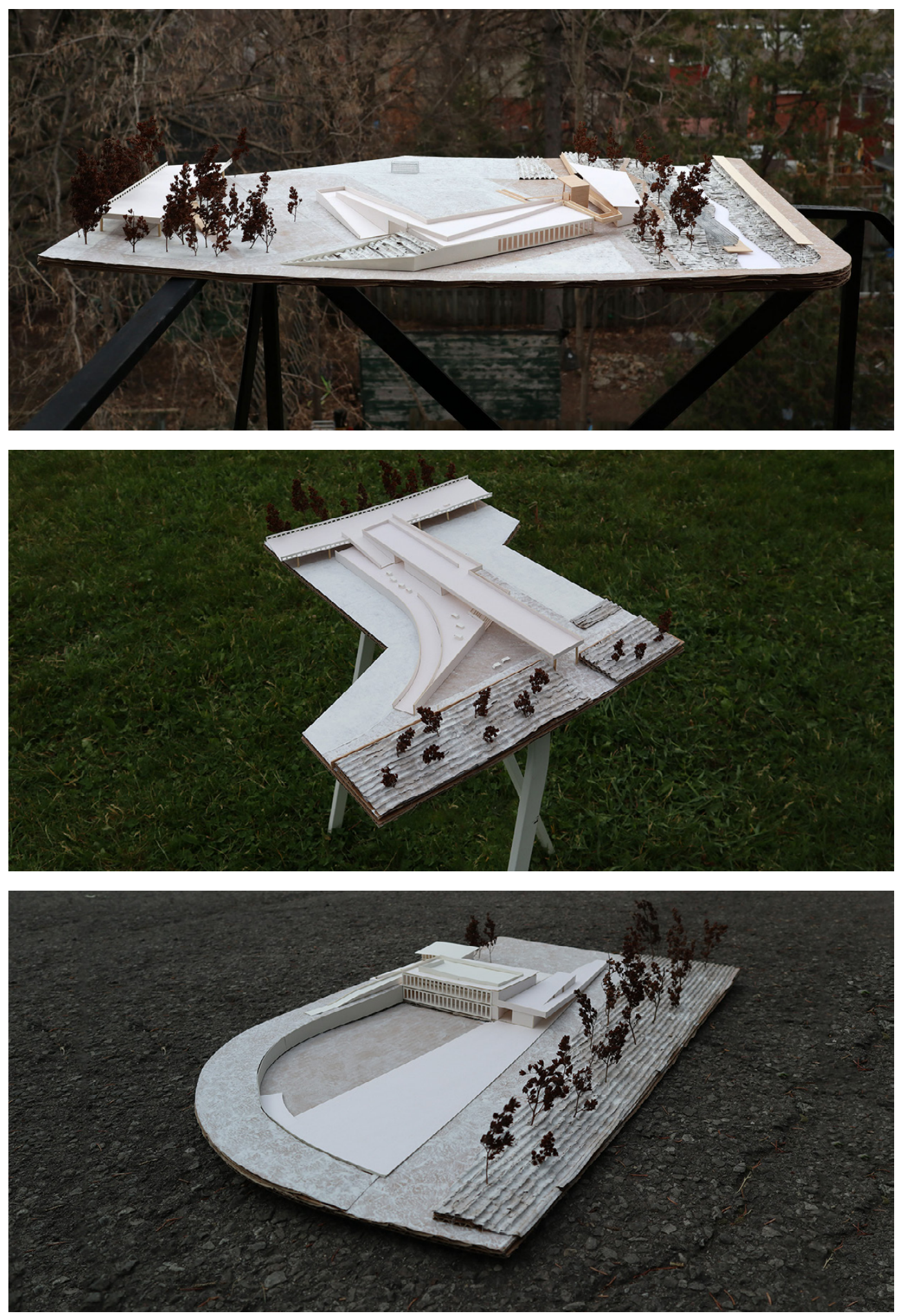

Figure 74. Seasonal Port and Restaurant

Figure 75 . Picnic Pavilion

Figure 76. The Gymnasium 


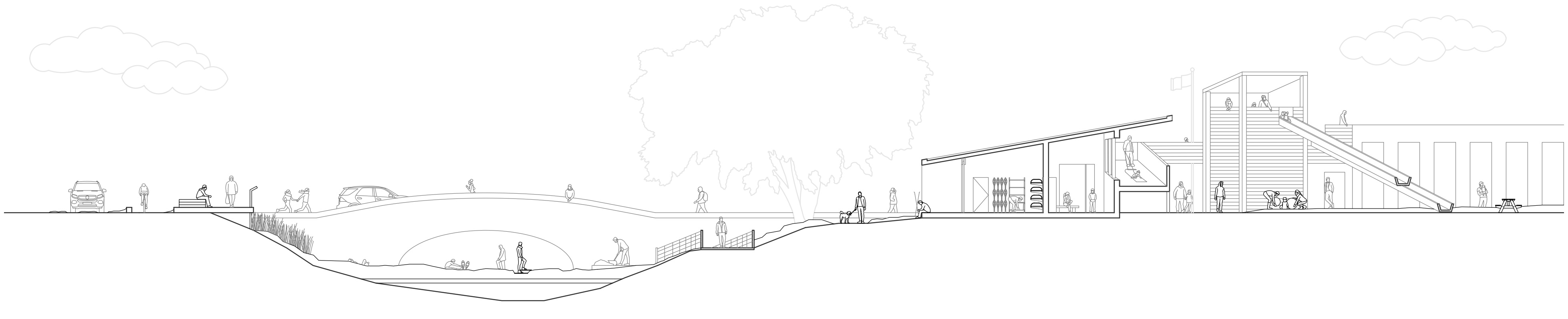

Figure 77 . Winter Site Section - Seasonal Port

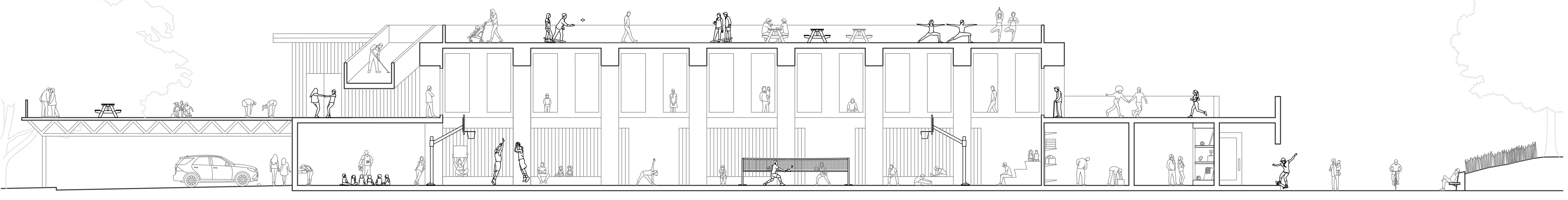



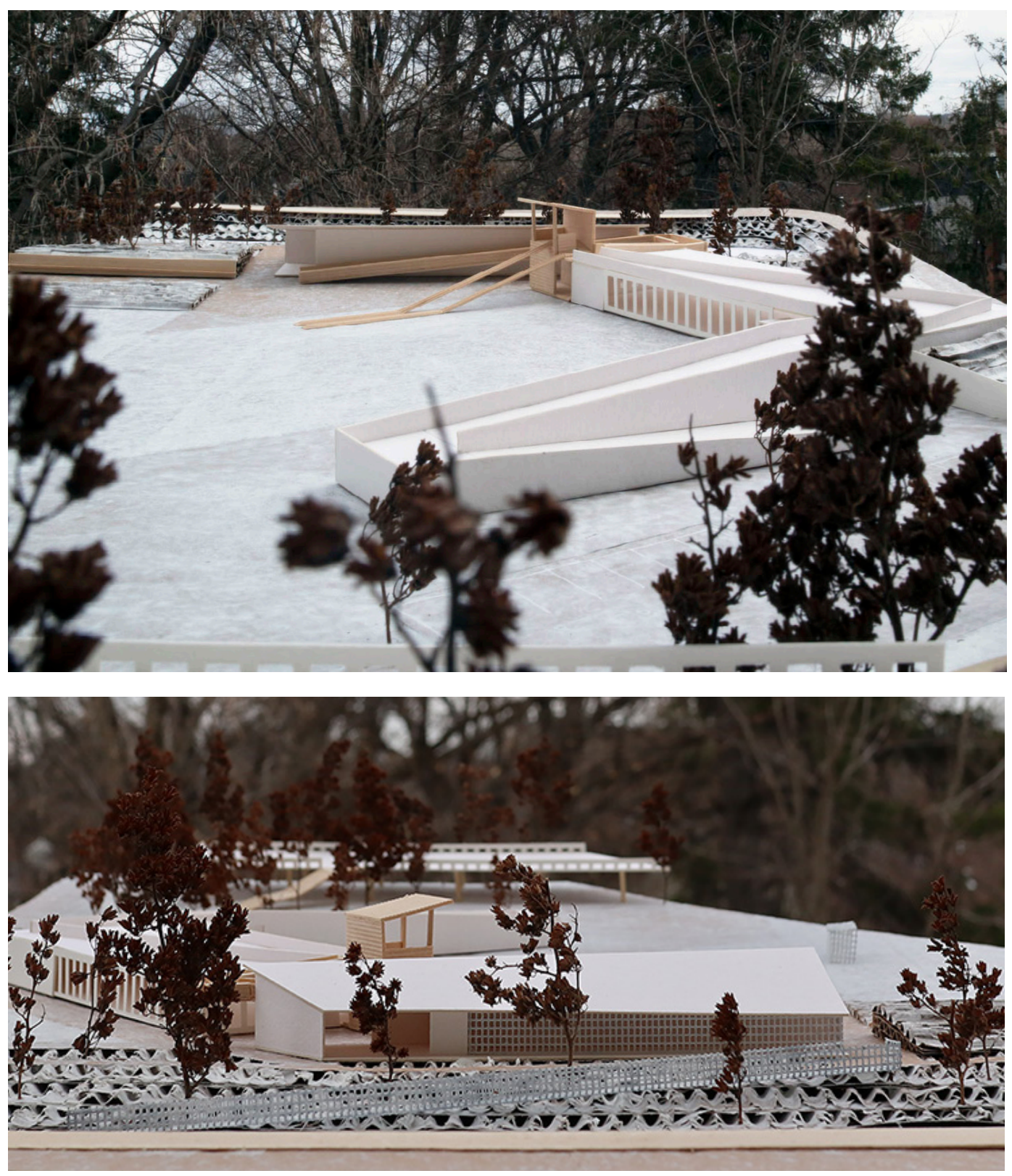

Figure 79. View from the Platform Figure 80 . View from the Boardwalk
Located in the middle of the prairies, Winnipeg has a very flat landscape. The gentle rise of each building opens up views and vistas to appreciate the rest of the site below. To engage and promote pedestrian traffic, a boardwalk extending the walkway on the opposite side of the creek invites passersby to rest and learn about the site from afar. 

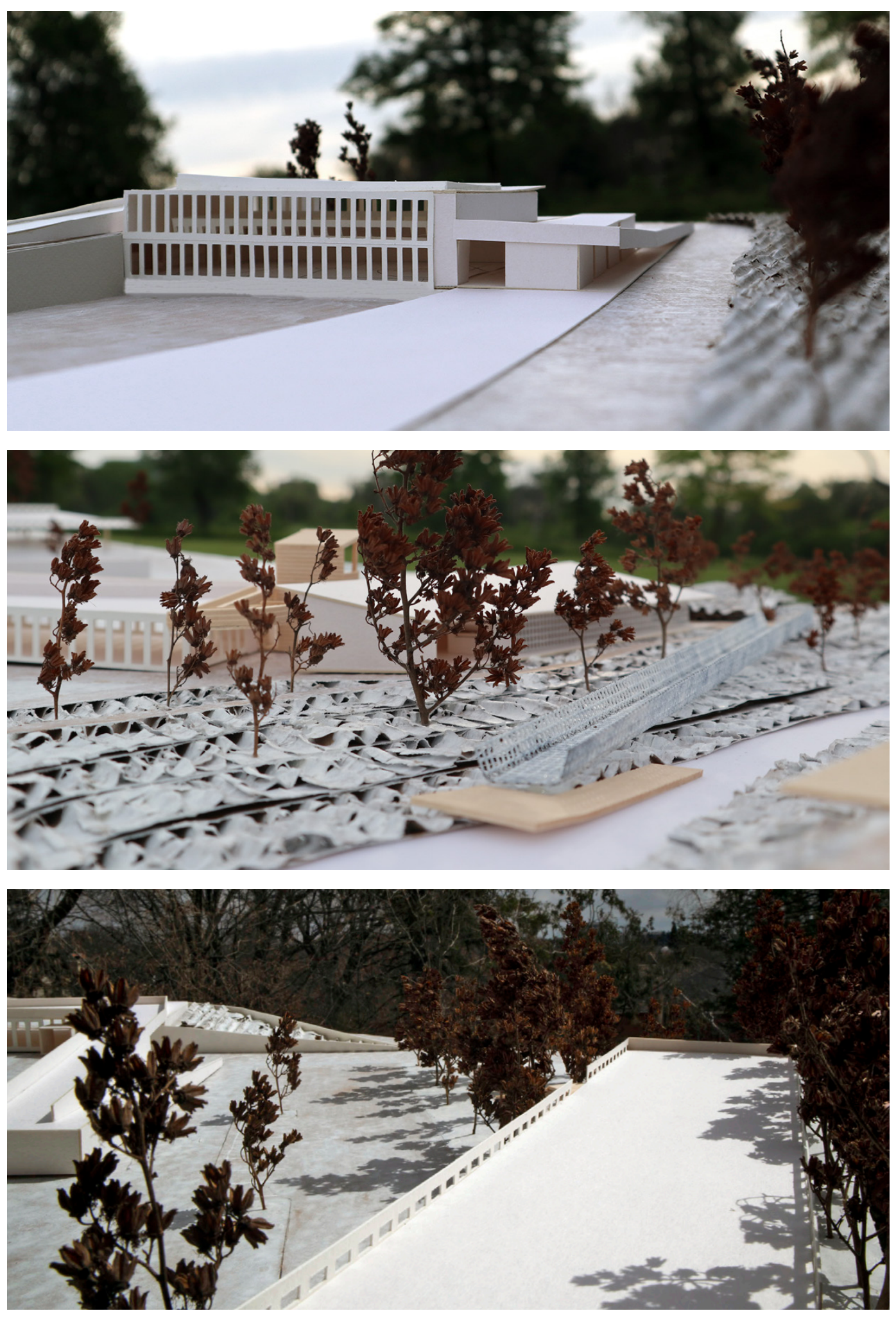

Figure 81 . Approach toward the Gymnasium

Figure 82. View toward Seasonal Port Dock

Figure 83. South end of the Platform 


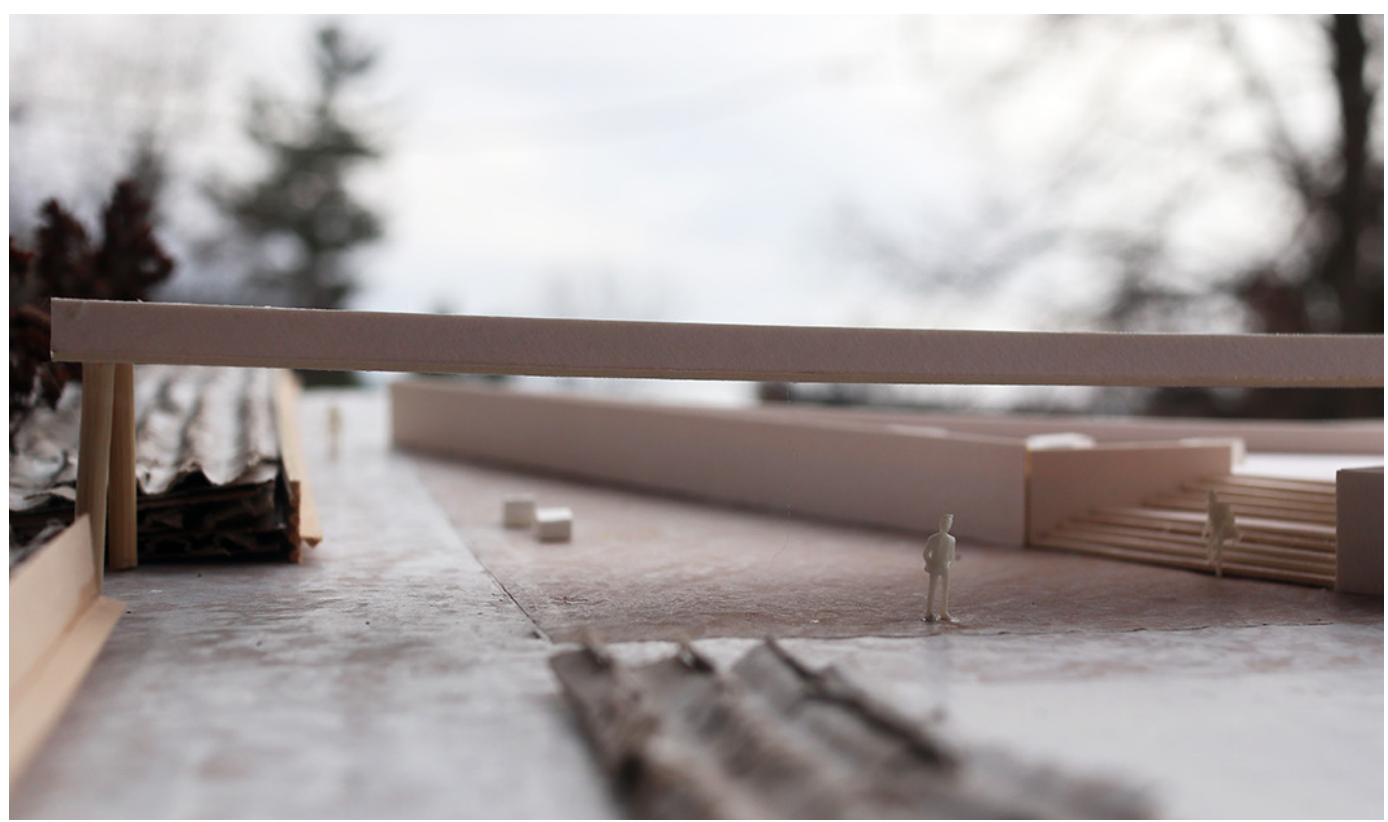

Figure 84 . Intersection at Picnic Pavilion
The main diagonal pathway cuts through the site

offering a wide route for active modes of travel. The path connects the buildings and staggers at junctions to break up the route and serve as distance markers for frequent visitors. Incremental distances can assist in setting goals and encourage physical activity in daily routines.

For environmental rehabilitation and physical recreation, the expropriation of the site will turn the land from a sterile urban landscape back to the diverse area that it once was. The site will restore the natural vegetation to continue the local residents' efforts and provide facilities to support recreational activity throughout the year. 
4.2 Building Proposals Each structure concentrates on different aspects

of recreation. The building at the north end of the site

focuses on how the body traverses the landscape.

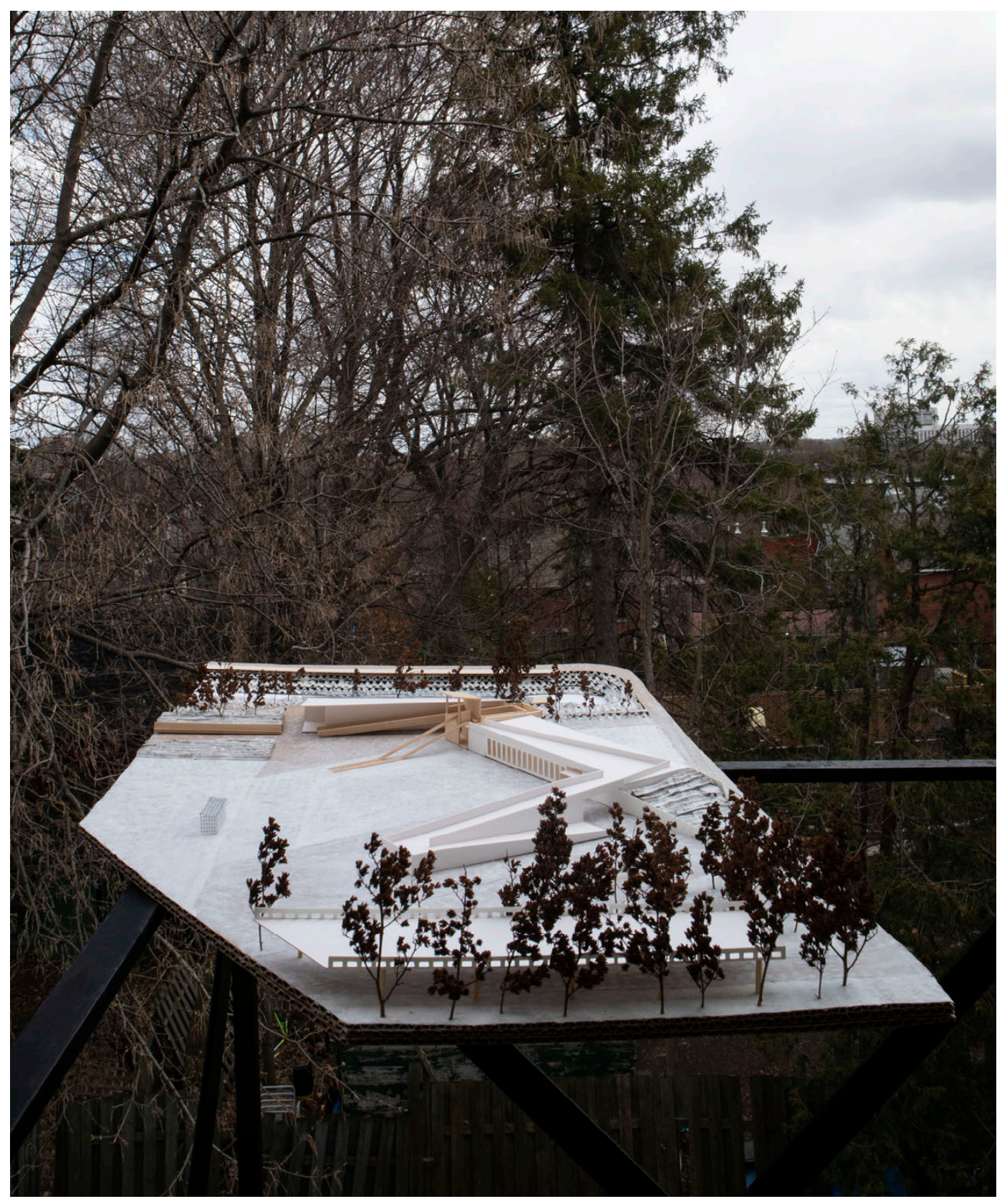

Figure 85 . North Buildings 


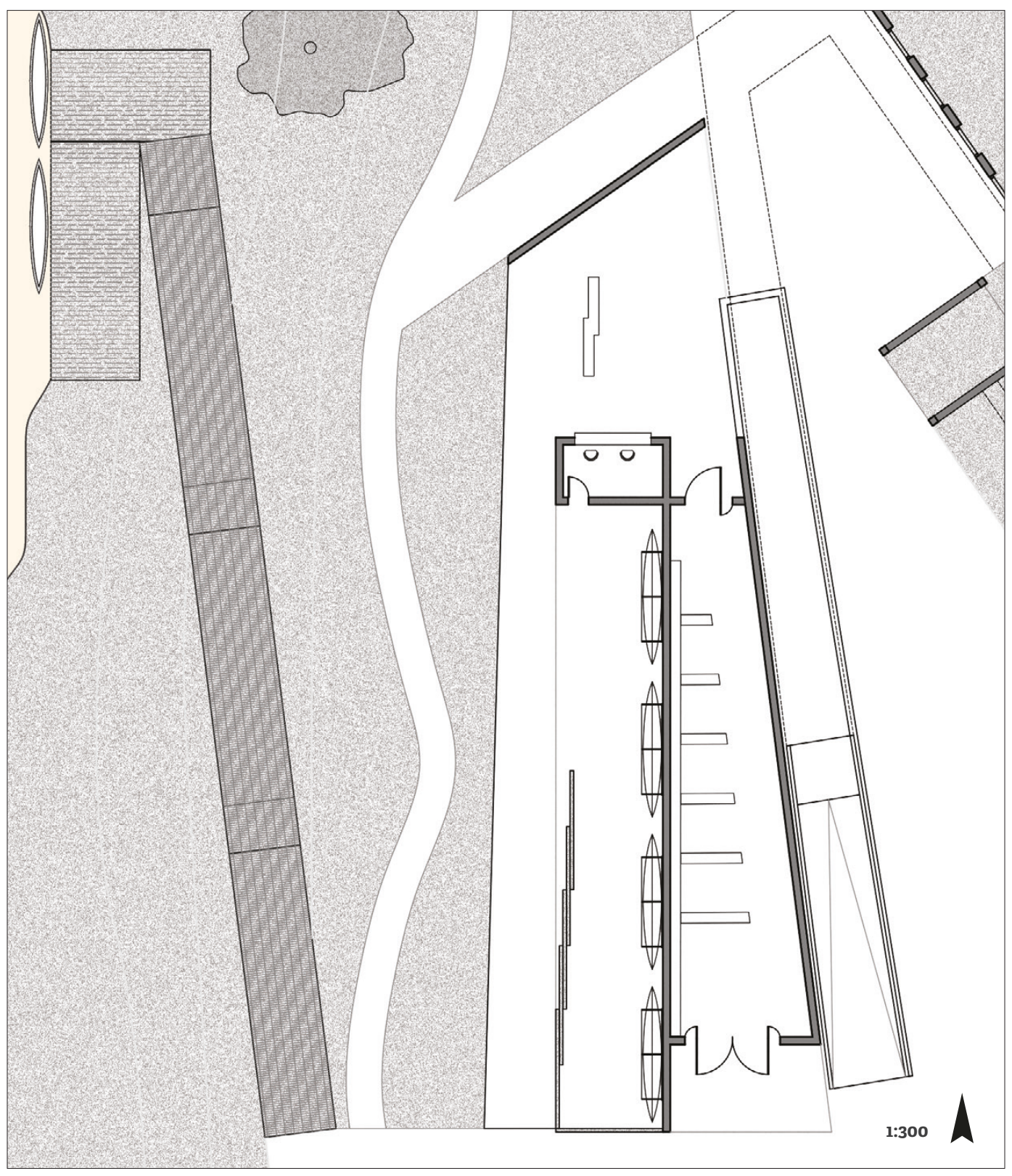

\section{Seasonal Port}

Figure 86. Seasonal Port Plan
A plaza welcomes visitors approaching the main

entryway privileging those arriving to the site without a vehicle to promote alternate forms of transportation over personal vehicles. Canoes, cross-country skis and snowshoes may be borrowed along the creek during different seasons. To communicate the amount of activity to the street, the storage for the equipment is made visible on the west side. 

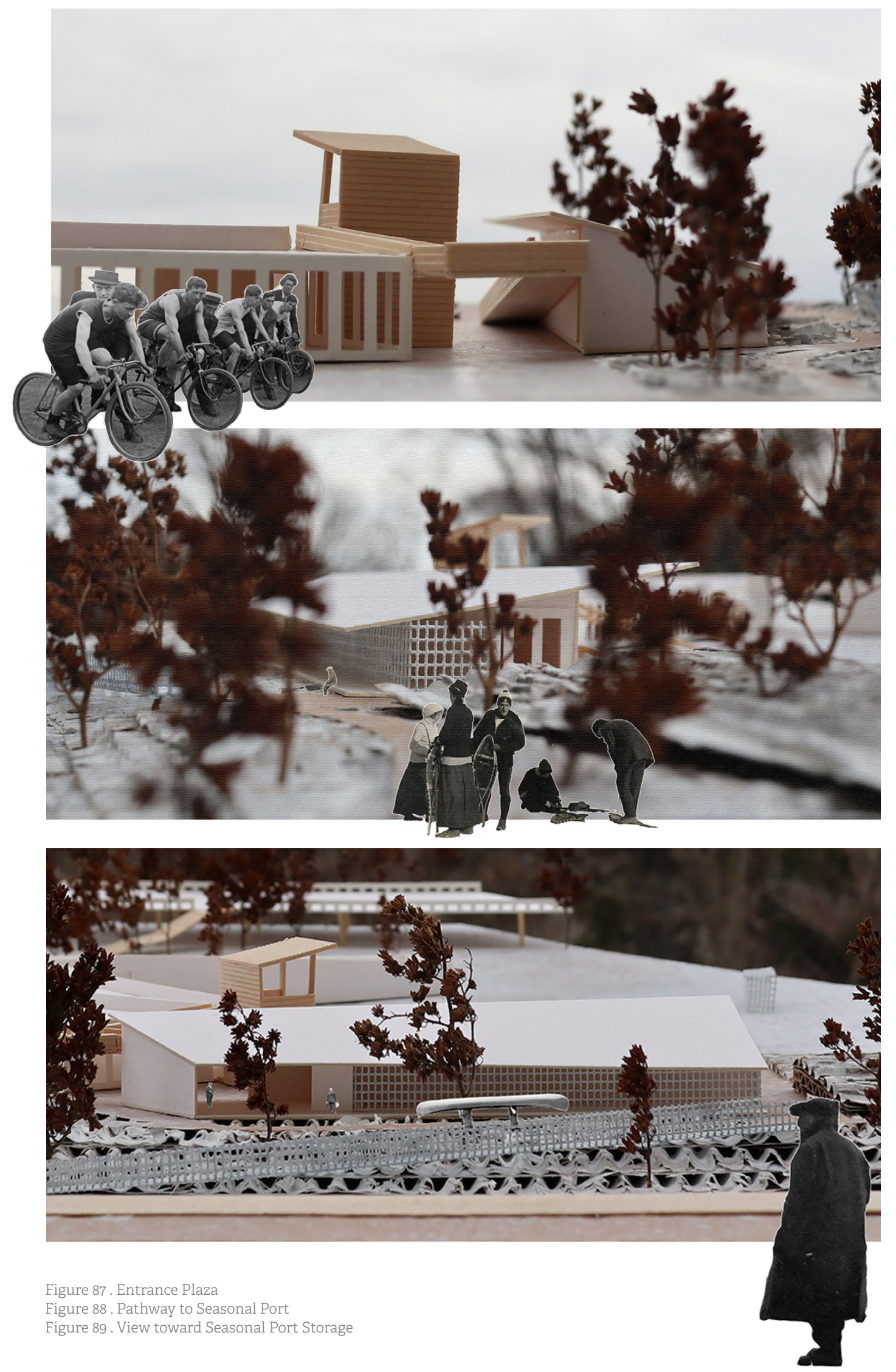


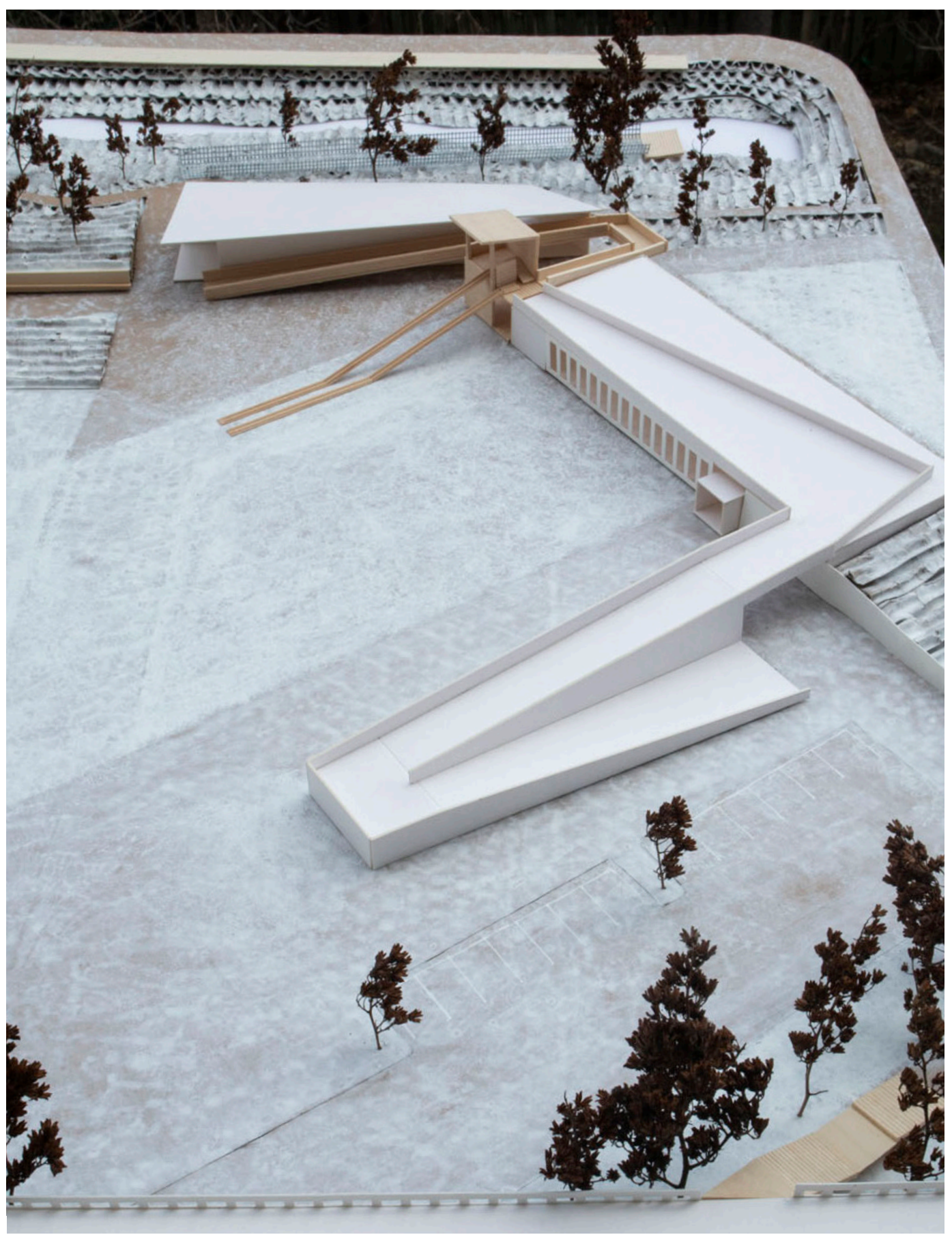

The ramp leading up to the toboggan run connect and exaggerate the movement and activity extending from the building and offer lookout points. An inhabitable roof offers a view toward the rest of the site and respite from the activity below. 


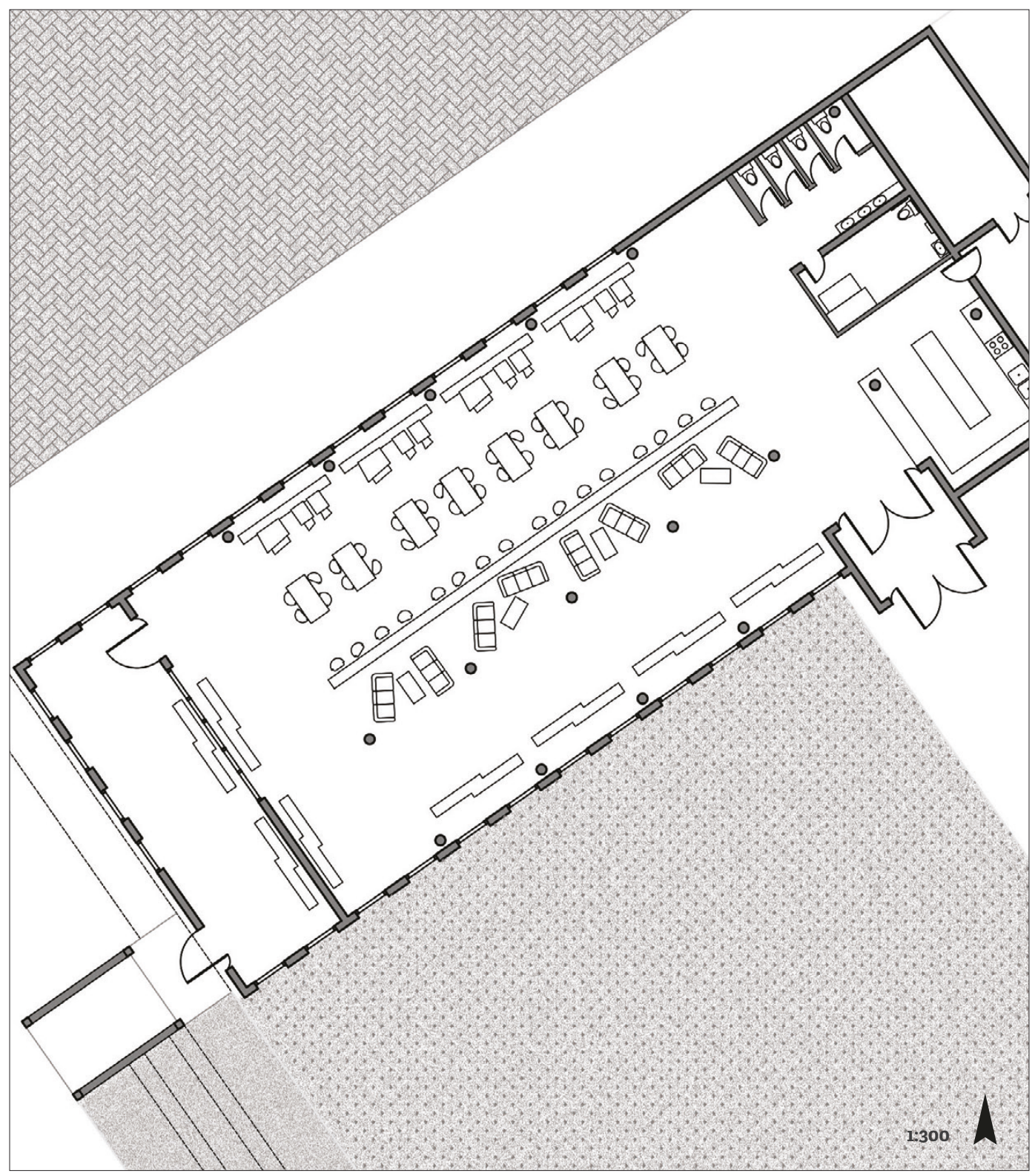

The Restaurant \& Cafe

Figure 91 . Restraurant \& Cafe Plan
The restaurant and cafe offer an accessible space for the elderly and parents with young children who may not necessarily take advantage of the entirety of the site, but are still able to enjoy the activity beyond. With the playground situated within view of the seated area, parents are able to able to visit while keeping an eye on their young ones and the elderly can enjoy the presence of children at play. 


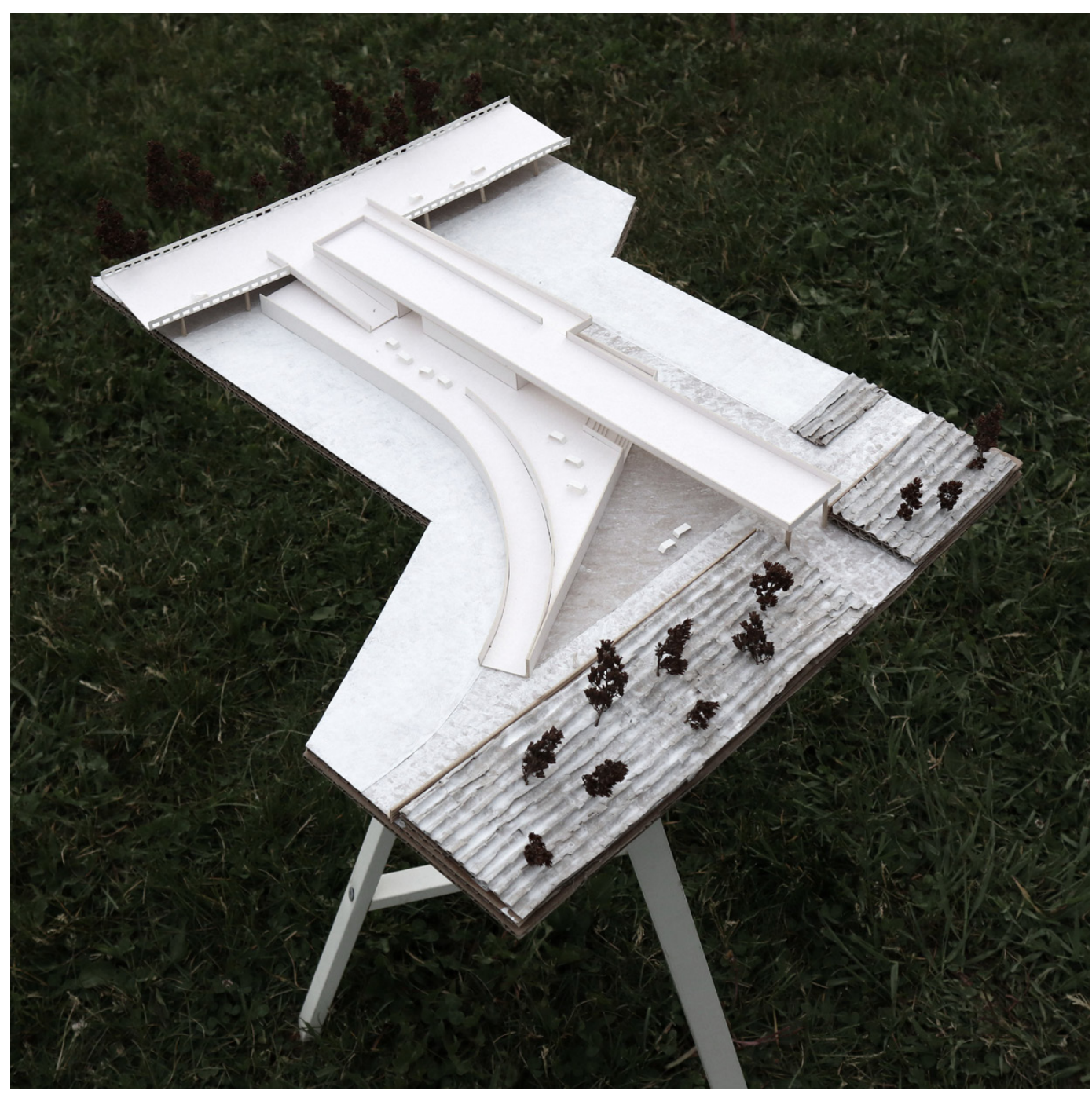

\section{Picnic Pavilion}

Figure 92. Picnic Pavilion
The first intersection meets the pavilion in the middle of the site and is designed for the nourishment of the body and soul. The pavilion provides a smaller gathering space along the path for an intimate moment of rest and leads visitors up to an open and covered picnic area looking out onto the fields on either side. Concession and restrooms are situated above for spectators, while locker and change rooms for athletes are located below. Various vantage points to both fields allow spectators to wander and enjoy the diverse spaces along the site. 


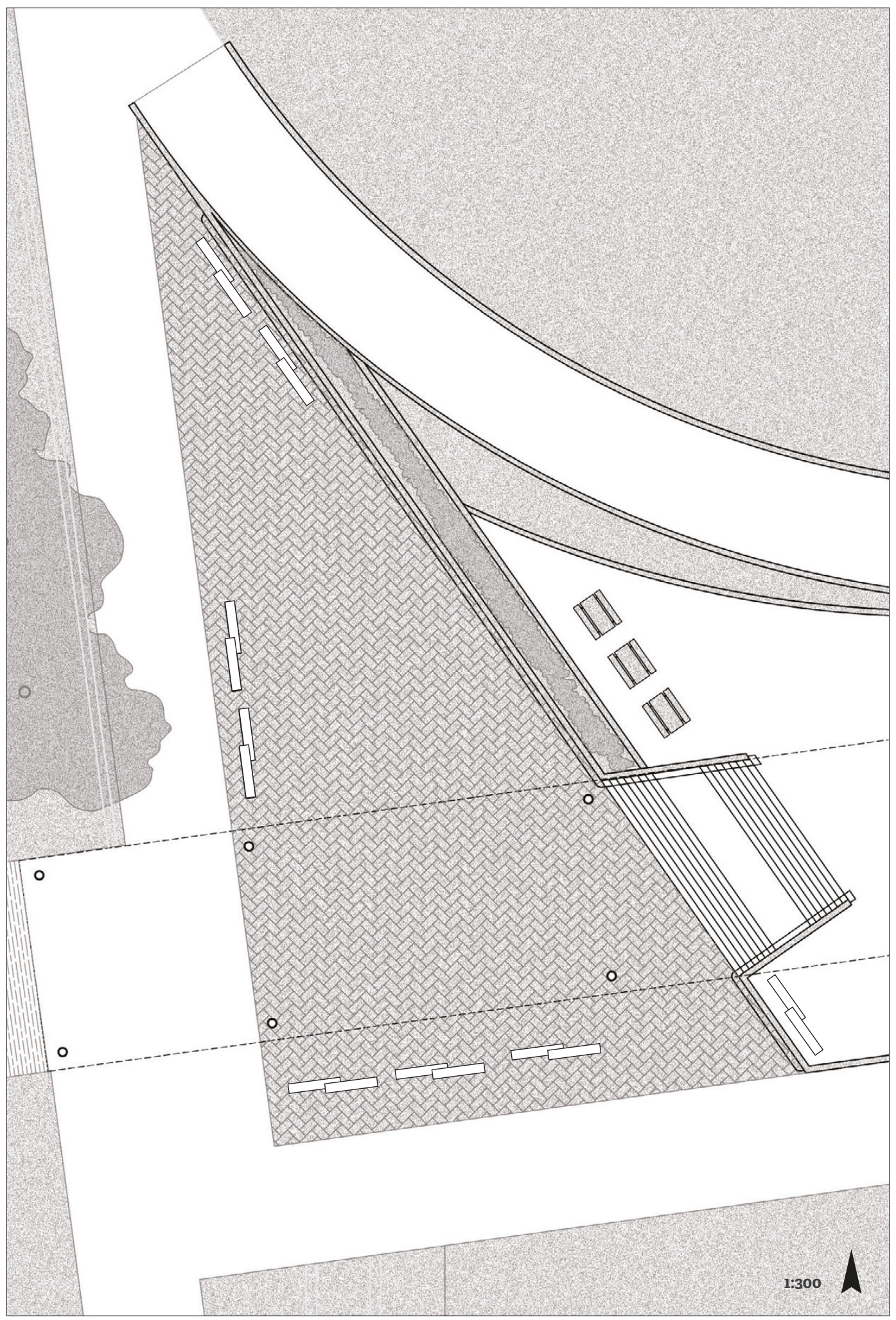

74

Figure 93 . Picnic Pavilion Entrance Plan 

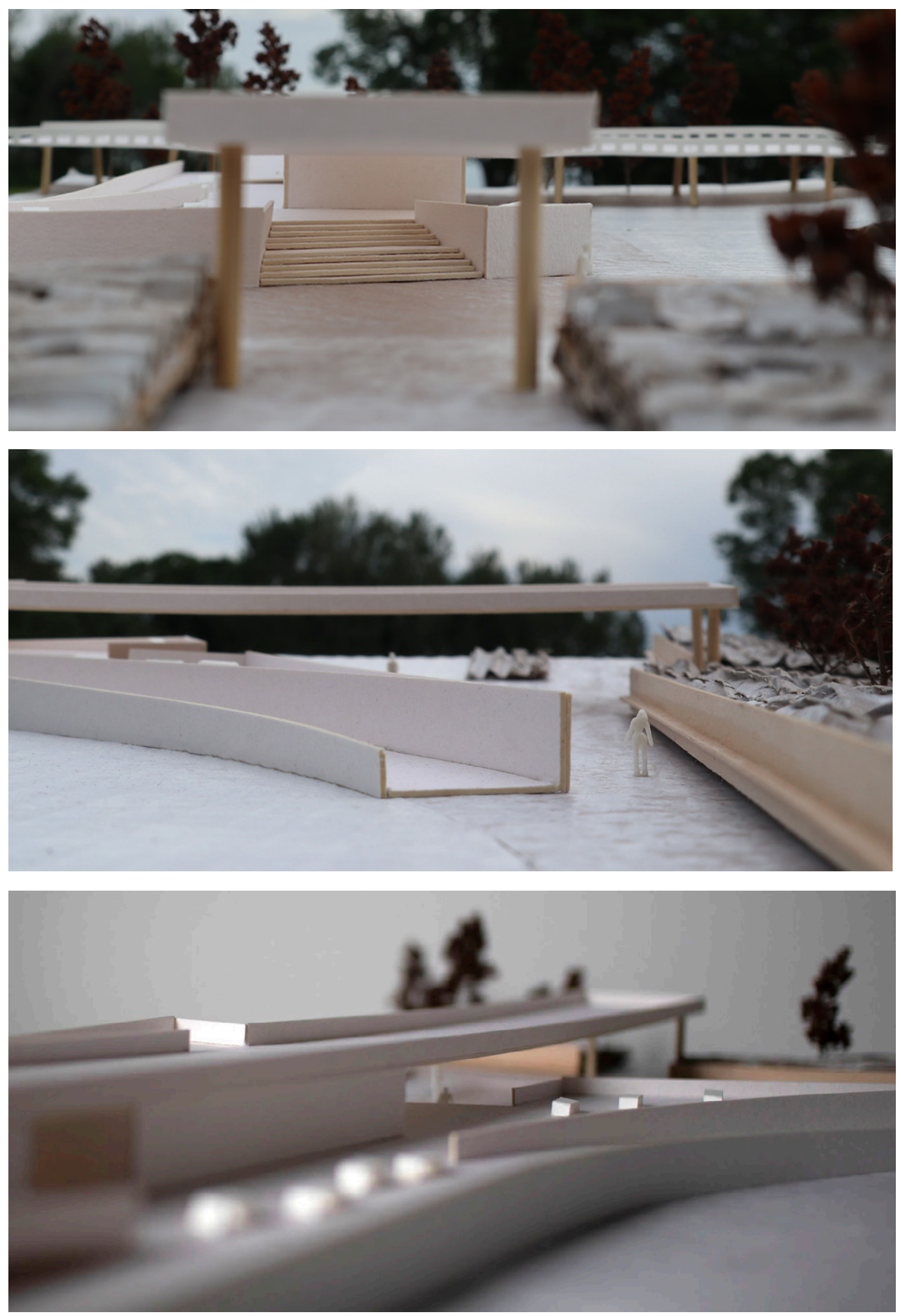

Figure 94 . Picnic Pavilion view from walking path

Figure 95. Picnic Pavilion view from main path

Figure 96 . Picnic Pavilion perspective 


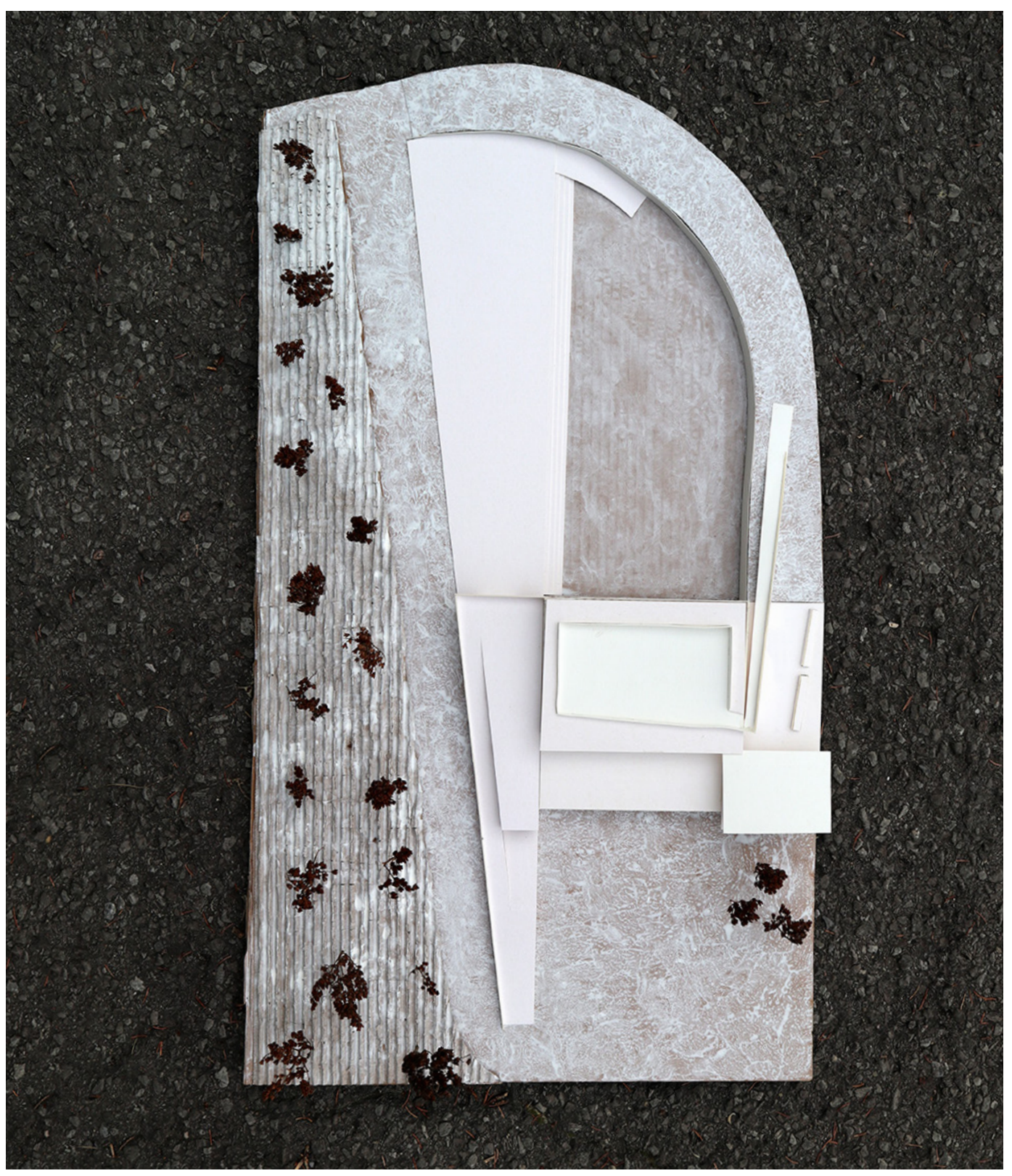

The Gymnasium

Figure 97. Gymnasium model
The third building, which is based on training the body, is situated at the south end of the site where the velodrome once stood. The path, intersecting the main route, follows the curve of the velodrome's footprint and leads visitors up above the plaza toward the roof of the building, providing views over the site and the surrounding area. 

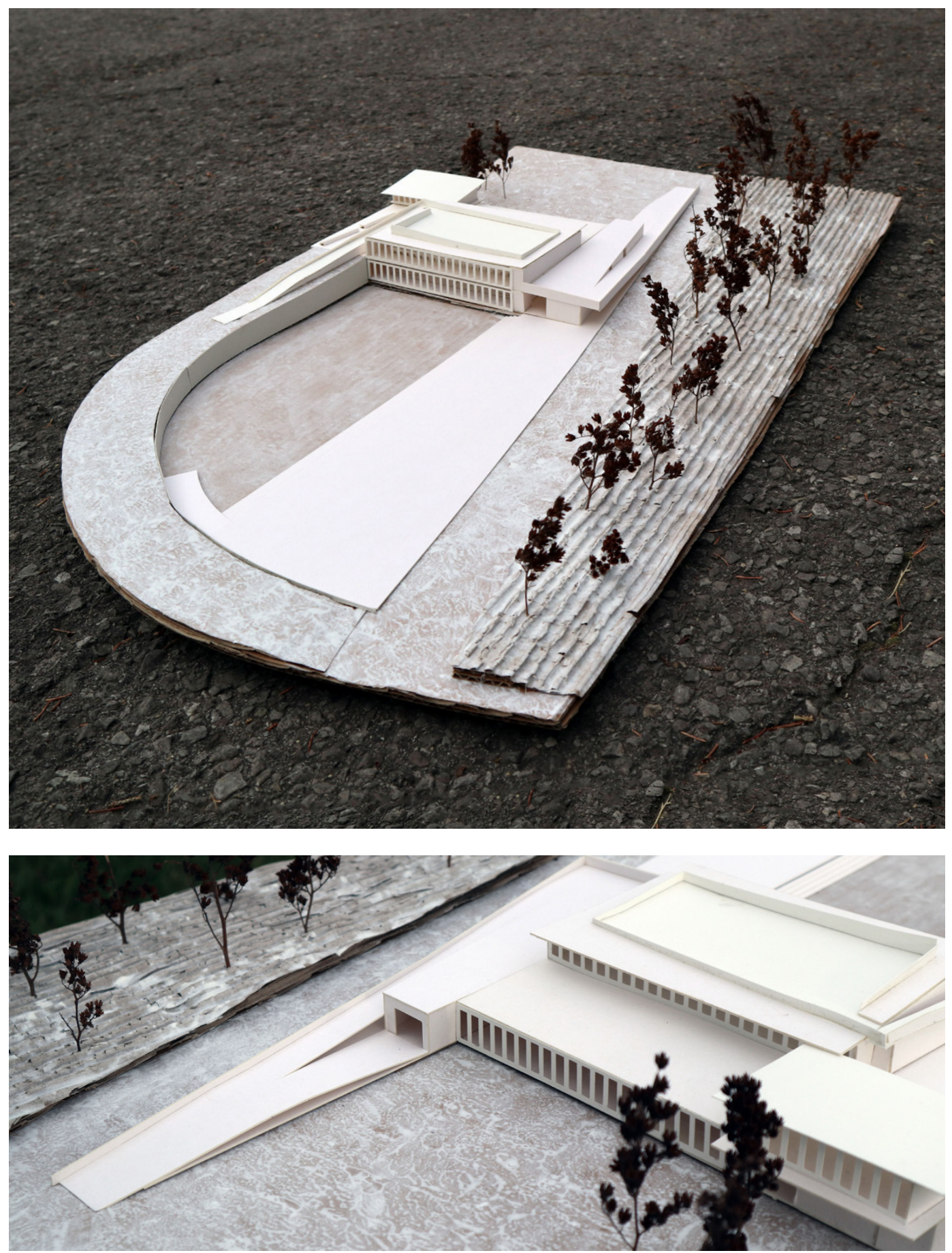

Figure 98. Gymnasium Plaza Figure 99 . South side of Gymnasium
The gymnasium facade is oriented north for natural daylighting without the distracting glare from the sun. Circulation on the interior and exterior of the building encounter different views and experiences along paths of travel with the gymnasium centrally visible. 


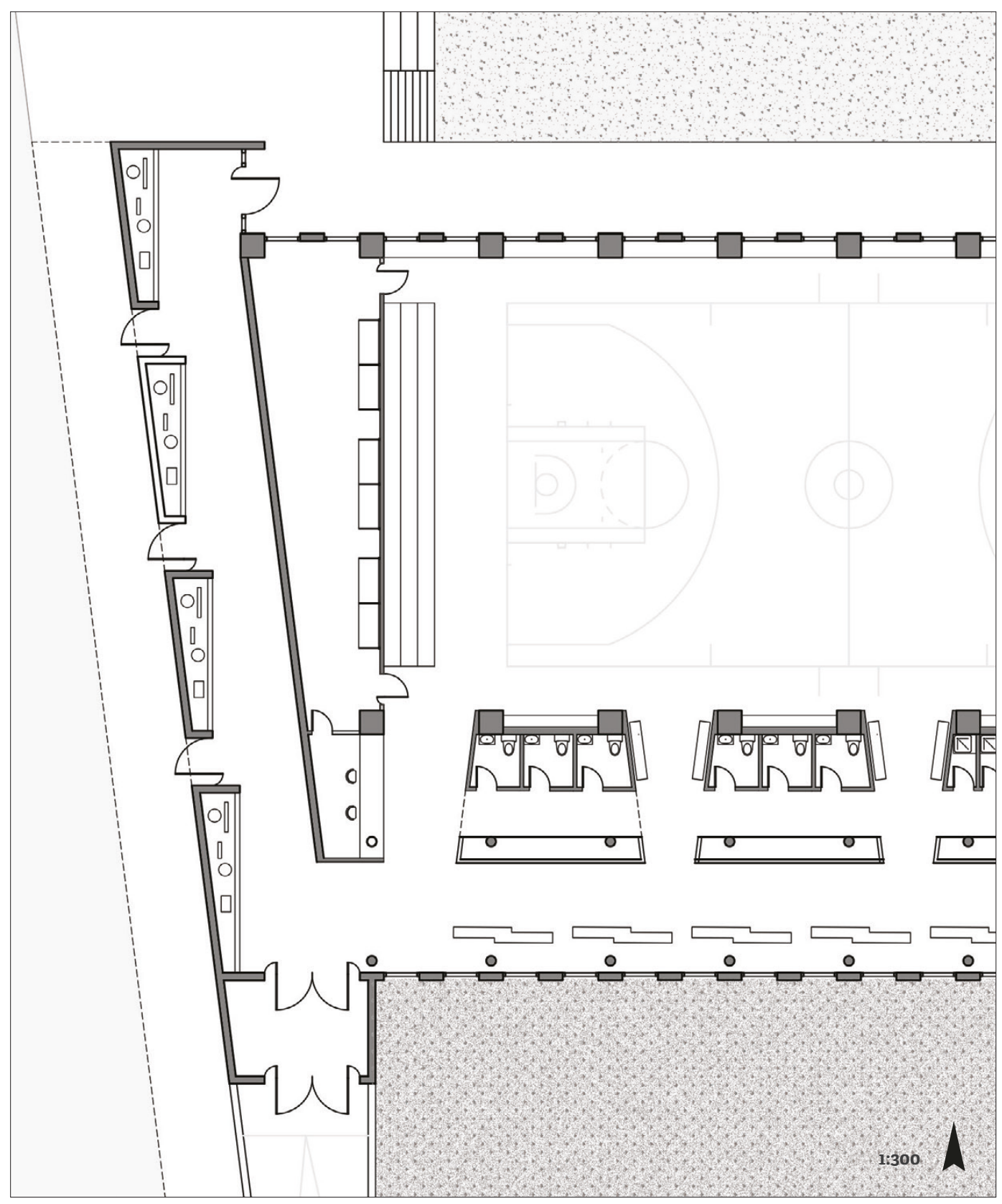

Figure 100. Gymnasium Plan

The entrance to the building invites visitors to slip

through the exhibition area and learn about the rich

history of recreation on site. Lockers and changerooms

exist as smaller rooms within a larger area, creating a

gender neutral social space before and after activity. The

transition from activity to rest is encountered with a

view toward the natural landscape to the south. 


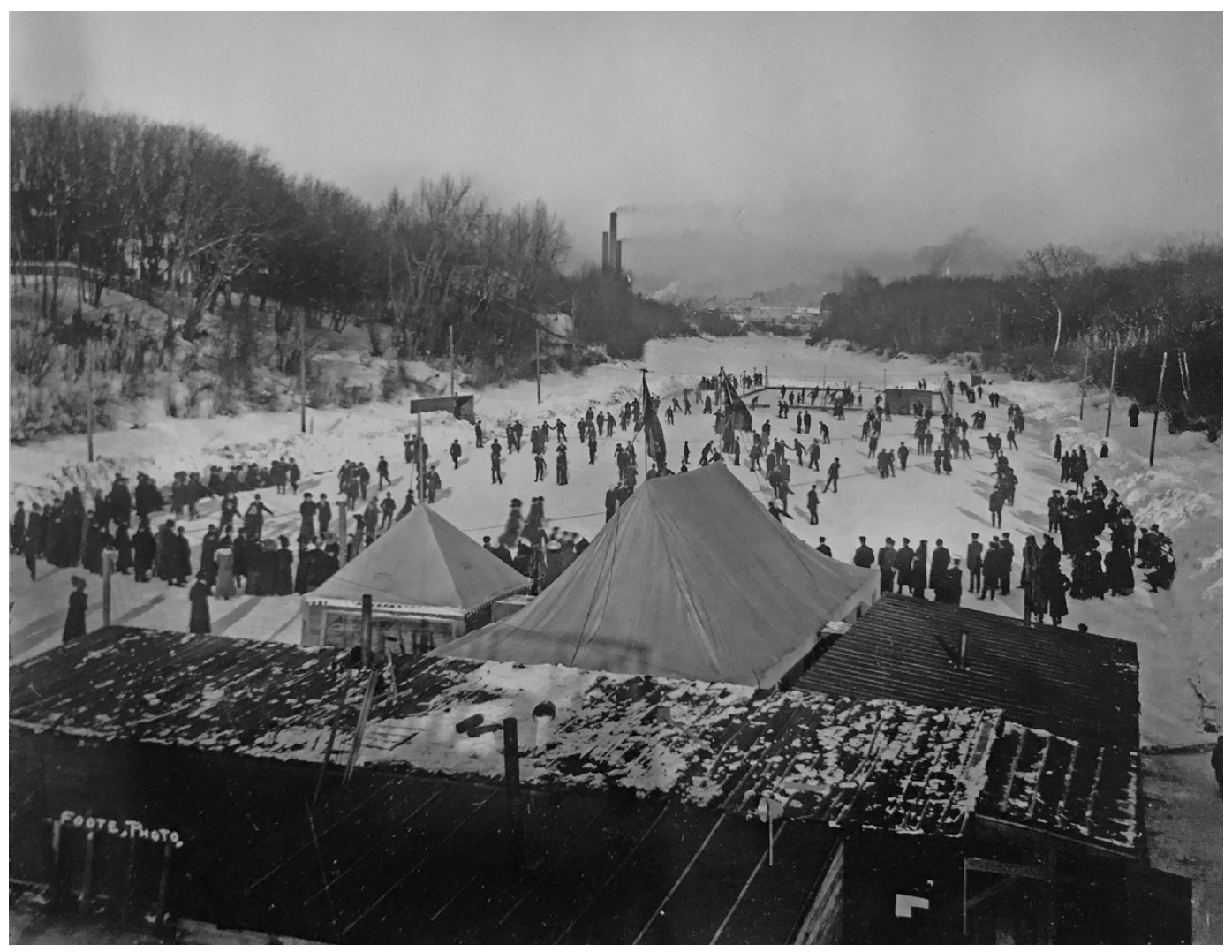

Figure 101 . L.B. Foote, Skating on the Red River at River Park, Osborne Street and Churchill Drive, 1914, Winnipeg.
The project is a reflection of our relationship with the land through physical activity within the growth of urban environments. Developing and maintaining active design in urban areas can not only assist with people's mental and physical health, but can also improve the impact we have on our environment. The project takes the wasted land and returns it to a recreational landscape for the public good in hopes of extending this physical culture toward other arteries of the city. 



\section{IMAGE SOURCES}

*All illustrations and images by author unless otherwise cited
Figure 1. Toboggan Slide, c. 1915, Assinaboine River, Winnipeg, Archives of Manitoba, Sport - Tobogganing 14.

Figure 2. Toboggan Slide, c. 1915, Assinaboine River, Winnipeg, Archives of Manitoba, Sport - Tobogganing 10, N17284.

Figure 3. Charles Meyers, c. 1925, Skating Scene Winnipeg, Assinaboine River, Winnipeg, Archives of Manitoba, Sport - Skating 1, N12674.

Figure 4. Nancy Dunbar and Hugh MacLennan, eds, Quotation (Images of Sport in Early Canada, Montreal: McGill-Queen's Univ. Press, 1976).

Figure 5. Nancy Dunbar and Hugh MacLennan, eds, Doll and toy toboggan, 192030, (Images of Sport in Early Canada, Montreal: McGill-Queen's Univ. Press, 1976).

Figure 6. Model Perspective.

Figure 7. Currier and Ives, Central Park, Winter, The Skating Pond, 1862, (Shubert, Howard. Architecture on Ice: A History of the Hockey Arena. McGill-Queen's/ Beaverbrook Canadian Foundation Studies in Art History. Montreal \& Kingston : London; Chicago: McGill-Queen's University Press, 2016).

Figure 8. YMCA Fundraising pamphlet for the Tulsa, ca. 1909, Oklahoma. YMCA Archives, University of Minnesota Libraries, Minneapolis. (Lupkin, Paula. Manhood Factories: YMCA Architecture and the Making of Modern Urban Culture. Architecture, Landscape, and American Culture Series. Minneapolis: University of Minnesota Press, 2010).

Figure 9. Y.M.C.A. Building, 1907, Winnipeg, Retrieved March 2020, https:// winnipeginfocus.winnipeg.ca/iol704

Figure 10. YMCA campaign clock at the corner of State and Madison, 1908, Chicago. Chicago Daily News negatives collection DN-0008209, Chicago History Museum, Chicago, Illinois. (Lupkin, Paula. Manhood Factories: YMCA Architecture and the Making of Modern Urban Culture. Architecture, Landscape, and American Culture Series. Minneapolis: University of Minnesota Press, 2010).

Figure 11. YMCA Campaign clock in Foochow, China, ca. 1915, YMCA Archives, University of Minnesota Libraries, Minneapolis. (Lupkin, Paula. Manhood Factories: YMCA Architecture and the Making of Modern Urban Culture. Architecture, Landscape, and American Culture Series. Minneapolis: University of Minnesota Press, 2010).

Figure 12 . [German Olympian, Luz Long, befriends Jesse Owens at the 1936 Berlin Olympic Games in Nazi Germany], Getty Images, retrieved December 2019, https:// www.entrepreneur.com/article/328050

Figure 13. Victoria Skating Rink, 1863, Toronto. (Shubert, Howard. Architecture on Ice: A History of the Hockey Arena. McGill-Queen's/Beaverbrook Canadian Foundation Studies in Art History. Montreal \& Kingston ; London ; Chicago: McGill-Queen's University Press, 2016.)

Figure 14. W.C. Chewitt and Co., Lacrosse, 1856-70, lithograph, Toronto. (Images of Sport in Early Canada, Montreal: McGill-Queen's Univ. Press, 1976).

Figure 15 . Eskimo Snowshoes (Images of Sport in Early Canada, Montreal: McGillQueen's Univ. Press, 1976).

Figure 16 . L.B. Foote, Group of immigrants arriving at CPR Station, Higgins Avenue and Main Street, 1927, Winnipeg. (Jones, Esyllt Wynne, and L. B. Foote. Imagining Winnipeg: History Through the Photographs of L.B. Foote. Winnipeg, Manitoba: University of Manitoba Press, 2012)

Figure 17. Valentine Edy Co., Ltd, A view of the lake in Assinboine Park in Winnipeg, 1920-1950, Winnipeg, Manitoba. retrieved March 2020, http://peel.library. ualberta.ca/postcards/PCoog639.html 
Figure 18 . [1967 Pan-American Game news articles], Pan-American Games (1967) Publishers, 1967.

Figure 19. Champion of the Century, April 1966, Panorama, Periodical Newsletter of the Pan-American Games 1967 Society, Winnipeg, Canada.

Figure 20. Transportation Map of Greater Winnipeg, 1941. Retrieved March 2020, https://www.transitmap.net/winnipeg-1941/

Figure 21. Polo Park Racetrack advertisement, 1925, Winnipeg Free Press, Retrieved October 2019, http://westenddumplings.blogspot.com/2009/08/polopark-opens-to-fanfare.html

Figure 22. Polo Park Shopping Centre advertisement, 1959. Retrieved October 2019,https://www.winnipegarchitecture.ca/wp-content/uploads/2014/12/1E2AFB4C4045-4DF3-BFB7-8A2981F36C24.jpeg

Figure 23 . [Outdoor activity at Omand's Creek], ca. 1960, Winnipeg Archives, Omand's Creek

Figure 24 . [Tobogganing at Omand's Creek], ca. 1960, Winnipeg Archives, Omand's Creek

Figure 25. Plan of River lots in the parishes of St. John, St. James and St. Boniface, 1874, Retrieved October 2019, https://www.flickr.com/photos/ manitobamaps/2079199096

Figure 26. The T. Eaton Co. Limited, T. Eaton Company Store in Portage Avenue, Winnipeg, ca. 1940, postcard, 9 x 14 cm, Winnipeg, Manitoba, Canada. Retrieved March 2020, http://peel.library.ualberta.ca/postcards/PCo13430.html

Figure 27. Eaton Park Place Golf Course surrounding Polo Park Racetrack, 1949, Aerial Photograph, Winnipeg, Retrieved January 2020, http://johndobbin.blogspot. com/2019/08/viscount-gort-polo-park-and-st-james.html

Figure 28. Polo Park, 1956, Postcard, Retrieved November 2019, https://www. asdowns.com/2016/06/27/field-of-dreams-brought-it-all-in-1977-polo-parkhandicap/

Figure 29. Victory Gift in the Polo Park Winner's Circle, 1948, photograph, Winnipeg, Retrieved October 2019, https://www.asdowns.com/2012/05/24/polopark-americas-finest-racing-plant/

Figure 30 . Bernard Brown, Drawings for Polo Park Shopping Centre, 1958, Winnipeg, Retrieved October 2019, https://www.winnipegarchitecture.ca/polopark-shopping-centre/

Figure 31. Gordon Goldsborough, Aerial view of Polo Park Shopping Centre, ca. 1960, Winnipeg, Retrieved October 2019, http://www.mhs.mb.ca/docs/sites/ polopark.shtml

Figure 32 . View to Simpsons-Sears, with sculptural Sundial Jim Willer and Duane Eicholz, ca. 1959. Retrieved October 2019, https://www.winnipegfreepress.com/ local/sears-lasting-impact-455268833.html

Figure 33. Chris Lund, George Swinton's Acrobats (Concrete), ca. 1959, photograph, Retrieved October 2019, https://www.winnipegarchitecture.ca/polopark-shopping-centre/

Figure 34 . Polo Park Mall Postcard, ca. 1963.

Figure 35 . Aerial Photograph of Polo Park area, ca. 1980, Winnipeg, Retrieved October 2019, https://www.flickriver.com/photos/9513047@N05/40762372512/

Figure 36 . Al Nickel, Canad Inns Stadium, photograph, retrieved June 2020, https://i.pinimg.com/originals/86/69/dd/8669dd970896b2bc859196cc3fd8588f.jpg

Figure 37. Gregg Burner, Line up for Jets tickets, May 17, 1978, Winnipeg Arena, photograph, UM Digital Collection, Retrieved October 2019, https://news. umanitoba.ca/the-price-of-ice-and-the-cost-of-hockey/ 
Figure 38 . Bryan Scott, Target Polo Park, 2015, photograph, Winnipeg, Retrieved

December 2019, https://www.flickr.com/photos/bryanscott/20306259775

Figure 39 . Bluestem Nature Park, photograph, 2019

Figure 40 . Garbage Hill, photograph, 2019

Figure 41. The Story of an Old Garden, Manitoba Archives

Figure 42 . Out for a Good Time: A Toboggan Party, c. 1915, photograph, Winnipeg, Manitoba Archives, Sport - Tobogganing 16, N20502

Figure 43 . Site History

Figure 44. Project Site

Figure 45 . Site exploration: south view of the creek, October 2019

Figure 46. Site exploration: north view from walking path, October 2019

Figure 47. Site exploration: south view of the creek, December 2019

Figure 48 . Site exploration: north view from walking path, December 2019

Figure 49. Site exploration: north view from bridge, December 2019

Figure 50. Site exploration: south view toward walking path, December 2019

Figure 51. The Surface Waters of Winnipeg: Rivers, Streams, Ponds and Wetlands, 1874-1984, City of Winnipeg Survey Department, retrieved November 2019, https:// www.cbc.ca/news/canada/manitoba/creeks-streams-winnipeg-history-1.4641823

Figure 52. [Omand's Creek during the 1950 Flood], 1950, Aerial photograph, Winnipeg, Winnipeg Archives, City Engineering Department flood scrapbooks and photographs, Accession 1979-05-14, Container 5.

Figure 53. Omand's Creek flooding at Portage Avenue, 1950, photograph, retrieved February 2020, https://www.flickriver.com/photos/9513047@N05/37270893764/

Figure 54.Proposed By-Law

Figure 55 . Brenda Fleming, Omand's Creek park sledding-ready, January 28, 1997, Winnipeg, The Herald, Winnipeg Archives.

Figure 56 . L.B. Foote, Free Press carriers' toboggan party at River Park, Osborne Street and Churchill Drive, 1919, photograph, Winnipeg, (Jones, Esyllt Wynne, and L. B. Foote. Imagining Winnipeg: History Through the Photographs of L.b. Foote. Winnipeg, Manitoba: University of Manitoba Press, 2012)

Figure 57. Playing Cards

Figure 58. Game Play

Figure 59 . Composite Drawing I

Figure 60. Composite Drawing II

Figure 61 . Composite Drawing III

Figure 62. Composite Drawing IV

Figure 63 . Site Study I - plan

Figure 64. Site Study I - roof

Figure 65. Site Study II - plan

Figure 66. Site Study II - spaces

Figure 67. Sketch Studies

Figure 68. Building Design Fall Term 
Figure 69. Outpost studies

Figure 70. Seasonal Port Entrance Perspective

Figure 71. Final Models

Figure 72. Site Plan Proposal

Figure 73. Winter Perspective Seasonal Port and Toboggan Slide

Figure 74. Seasonal Port and Restaurant

Figure 75 . Picnic Pavilion

Figure 76. The Gymnasium

Figure 77. Winter Site Section - Seasonal Port

Figure 78. Summer Site Section - The Gymnasium

Figure 79. View from the Platform

Figure 80 . View from the Boardwalk

Figure 81. Approach toward the Gymnasium

Figure 82. View toward Seasonal Port Dock

Figure 83 . South end of the Platform

Figure 84 . Intersection at Picnic Pavilion

Figure 85 . North Buildings

Figure 86 . Seasonal Port Plan

Figure 87 . Entrance Plaza

Figure 88. Pathway to Seasonal Port

Figure 89 . View toward Seasonal Port Storage

Figure 90. Lookouts and roofscapes

Figure 91 . Restraurant \& Cafe Plan

Figure 92 . Picnic Pavilion

Figure 93. Picnic Pavilion Entrance Plan

Figure 94 . Picnic Pavilion view from walking path

Figure 95. Picnic Pavilion view from main path

Figure 96 . Picnic Pavilion perspective

Figure 97 . Gymnasium model

Figure 98 . Gymnasium Plaza

Figure 99. South side of Gymnasium

Figure 100. Gymnasium Plan

Figure 101 . L.B. Foote, Skating on the Red River at River Park, Osborne Street and Churchill Drive, 1914, Winnipeg. (Jones, Esyllt Wynne, and L. B. Foote. Imagining Winnipeg: History Through the Photographs of L.B. Foote. Winnipeg, Manitoba: University of Manitoba Press, 2012) 
BIBLIOGRAPHY
Bale, John. Sport, Space, and the City. London; New York: Routledge, 1993.

Bernhardt, Darren. “Ghost Creeks: Winnipeg Buried Many Waterways That Could Have Changed City's Shape." CBC News, September 2, 2018. https://www.cbc.ca/news/canada/manitoba/ creeks-streams-winnipeg-history-1.4641823.

Cheng, Irene, ed. “Active Design Guidelines: Promoting Physical Activity and Health in Design." Center for Active Design, 2010. https://centerforactivedesign.org/dl/guidelines.pdf.

Gold, John R. 1998. "Creating the Charter of Athens: CIAM and the Functional City, 1933-43." Liverpool University Press Vol. 69, No. 3 (The Town Planning Review): 225-47.

Gold, John R., and Margaret M. Gold, eds. Olympic Cities: City Agendas, Planning and the World's Games, 1896-2020. Third edition. Planning, History and Environment Series. London ; New York, NY: Routledge Taylor \& Francis Group, 2016.

“International WELL Building Institute." WELL. Accessed August, 2019. http://www.wellcertified.com/.

Klinenberg, Eric. Palaces for the People: How Social Infrastructure Can Help Fight Inequality, Polarization, and the Decline of Civic Life. First Edition. New York: Crown, 2018.

Lady Allen of Hurtwood. Planning for Play. London: Thames and Hudson, 1971.

Le Corbusier. 1973. The Athens Charter. New York: Grossman Publishers.

Lidin, Konstantin. "Between the Show and the War: Sports as a generator of emotions and architecture of sports venues." Project Baikal, no. 51 (March 31, 2017): 38-49 Pages. https://doi. org/10.7480/PROJECTBAIKAL.51.1114.

Lupkin, Paula. Manhood Factories: YMCA Architecture and the Making of Modern Urban Culture. Architecture, Landscape, and American Culture Series. Minneapolis: University of Minnesota Press, 2010.

Macdonald, Catherine Logan, Winnipeg (Man.), and Parks and Recreation Department. A City at Leisure: An Illustrated History of Parks and Recreation Services in Winnipeg 1893-1993. Winnipeg, MB: City of Winnipeg, Parks and Recreation Dept., 1995. 
Morrow, Don, and Kevin B. Wamsley. Sport in Canada: A History. Third edition. Don Mills, Ontario, Canada: Oxford University Press, 2013.

Winnipeg Architecture Foundation. "Polo Park Shopping Centre." Accessed December 19, 2019. https://www. winnipegarchitecture.ca/polo-park-shopping-centre/.

Pruden, Eileen. “The Other Polo Park." Winnipeg Real Estate News, April 28, 1989.

Province of Manitoba. "Red River Floodway." Government. Accessed December 20, 2019. https://www.gov.mb.ca/mit/wms/ rrf/index.html.

Schaillée, Hebe, Reinhard Haudenhuyse, and Lieve Bradt. "Community Sport and Social Inclusion: International Perspectives." Sport in Society 22, no. 6 (June 3, 2019): 885-96. https://doi.org/10.1080/17430437.2019.1565380.

Shubert, Howard. Architecture on Ice: A History of the Hockey Arena. McGill-Queen's/Beaverbrook Canadian Foundation Studies in Art History. Montreal \& Kingston; London; Chicago: McGill-Queen's University Press, 2016.

Steinbach, Alison. “Competition, Cooperation, and Cultural Entertainment." Harvard International Review 37, no. 2 (Winter 2016): 35-39. http://search.ebscohost.com/login. aspx?direct $=$ true $\&$ site $=e d s-l i v e \& d b=b s u \& A N=114852069$.

Spector, David. Assiniboine Park: Designing and Developing a People's Playground. Winnipeg, MB: Great Plains Publications, 2019.

Thorsteinson, Jeffrey, Brennan Smith, and Winnipeg Architecture Foundation. GBR: Green Blankstein Russell and Associates : An Architectural Legacy, 2017.

Wilson, Keith, and Antoine S Lussier. Off and Running: Horse Racing in Manitoba. Winnipeg: Peguis Publishers, 1978. 
